\title{
WestVirginiaUniversity
}

THE RESEARCH REPOSITORY @ WVU

Graduate Theses, Dissertations, and Problem Reports

2006

\section{Cerulean warbler selection of forest canopy gaps}

\author{
Kelly A. Perkins \\ West Virginia University
}

Follow this and additional works at: https://researchrepository.wvu.edu/etd

\author{
Recommended Citation \\ Perkins, Kelly A., "Cerulean warbler selection of forest canopy gaps" (2006). Graduate Theses, \\ Dissertations, and Problem Reports. 2369. \\ https://researchrepository.wvu.edu/etd/2369
}

This Thesis is protected by copyright and/or related rights. It has been brought to you by the The Research Repository @ WVU with permission from the rights-holder(s). You are free to use this Thesis in any way that is permitted by the copyright and related rights legislation that applies to your use. For other uses you must obtain permission from the rights-holder(s) directly, unless additional rights are indicated by a Creative Commons license in the record and/ or on the work itself. This Thesis has been accepted for inclusion in WVU Graduate Theses, Dissertations, and Problem Reports collection by an authorized administrator of The Research Repository @ WVU. For more information, please contact researchrepository@mail.wvu.edu. 


\title{
Cerulean Warbler Selection of Forest Canopy Gaps
}

\author{
Kelly A. Perkins
}

Thesis submitted to the Davis College of Agriculture, Forestry, and Consumer Sciences at West Virginia University

in partial fulfillment of the requirements for the degree of

\author{
Master of Science \\ in \\ Wildlife and Fisheries Resources \\ Petra Bohall Wood, Ph.D., Chair \\ John W. Edwards, Ph.D. \\ Susan Olcott, M.S.
}

Division of Forestry and Natural Resources

Morgantown, West Virginia
2006

Keywords: canopy gap, Cerulean Warbler, core area, Dendroica cerulea, territory size, time-activity budget 


\title{
ABSTRACT \\ Cerulean Warbler Selection of Forest Canopy Gaps
}

\author{
Kelly A. Perkins
}

Forest canopy gaps are thought to be an important component in Cerulean Warbler (Dendroica cerulea) habitat. This study examined the selection of forest canopy gaps within Cerulean Warbler (Dendroica cerulea) territories and in core areas of territories on the Lewis Wetzel Wildlife Management Area and surrounding properties in Wetzel County, West Virginia in 2004 and 2005. The study objectives were to 1) determine the use and selection of gaps according to type, size, and structure, 2) determine if gap size was related to gap density, total gap area (\%), or perimeter amount, and 3) determine if distances of territories to large gaps and edge was related to the edge type or size.

Cerulean Warbler territories were mapped and minimum convex polygon methods were used to estimate territory boundaries in 2004. In 2005, territory sizes and core areas were delineated using $95 \%$ and 50\% fixed kernel estimates. Gap densities were highest within core areas of territories and the smallest territories had the highest gap densities indicating that gaps provided an important resource. Selection of gaps with vegetative heights of 12-18 m and surrounding canopy heights of $>24 \mathrm{~m}$ occurred within territory core areas but these findings were not consistent across sites. Larger gaps such as wildlife food plots were located more often on the periphery of territories while smaller gaps such as treefalls were more frequently located inside of territories. Forest management practices that create small gaps $\left(<100 \mathrm{~m}^{2}\right)$ within an otherwise dense canopy and encourage forest growth towards an old-growth structure may benefit this species.

Time-activity budgets of male Cerulean Warblers (Dendroica cerulea) were examined on two sites in 2005. Singing and foraging were the most frequently observed of 11 documented behaviors. Cerulean Warbler males sang in the upper-canopy and foraged in the lower and mid-canopy more frequently than expected. On one site, singing occurred more frequently than expected within core areas while foraging occurred more frequently than expected in non-core areas. The allocation of singing and foraging behavior among canopy strata may provide an explanation of the affinity that this species exhibits for a vertically stratified forest canopy. 


\section{ACKNOWLEDGMENTS}

Funding for this project was provided by the Wildlife Diversity Program within the Wildlife Resources Section of the West Virginia Division of Natural Resources (WVDNR). Logistic and administrative support was provided by the USGS WV Cooperative Fish and Wildlife Resources Unit and the Division of Forestry and Natural Resources at West Virginia University. Land access at the study site was provided by WVDNR, Wheeling Jesuit University, and the Outlaw Hunt Club. Housing at the field site in 2005 was provided by Wheeling Jesuit University.

I would like to especially thank my advisor, Dr. Petra Bohall Wood, for the opportunity to work on this project and for all of her help and guidance throughout the process. I would like to thank my graduate committee Dr. John Edwards and Susan Olcott for all of their support and advice.

I would like to thank my field help: Michelle Carder, Jennifer Eells, Michael Lutmerding, Lindsy McKenzie, Brandon Miller, Jennifer Saville, and Amanda Stripple. I couldn't have asked for a better crew. I was amazed by your resolve and ability and am grateful to you for keeping me laughing and for sticking it out. Special thanks go to Mikey and Jen who saw the field side of this project through from the start to finish.

I would also like to thank Jacquelyn Strager for GIS help, Dr. George Seidel for statistics advice, Bert Nolan for logistic support at the field site, Dr. Ray Hicks for advice regarding forest management practices, and Becky Nestor for everything she does behind-the-scenes.

I would like to thank my family and friends for their enthusiasm and support and especially my parents for valuing education and for always being supportive of the direction that I chose. 


\section{TABLE OF CONTENTS}

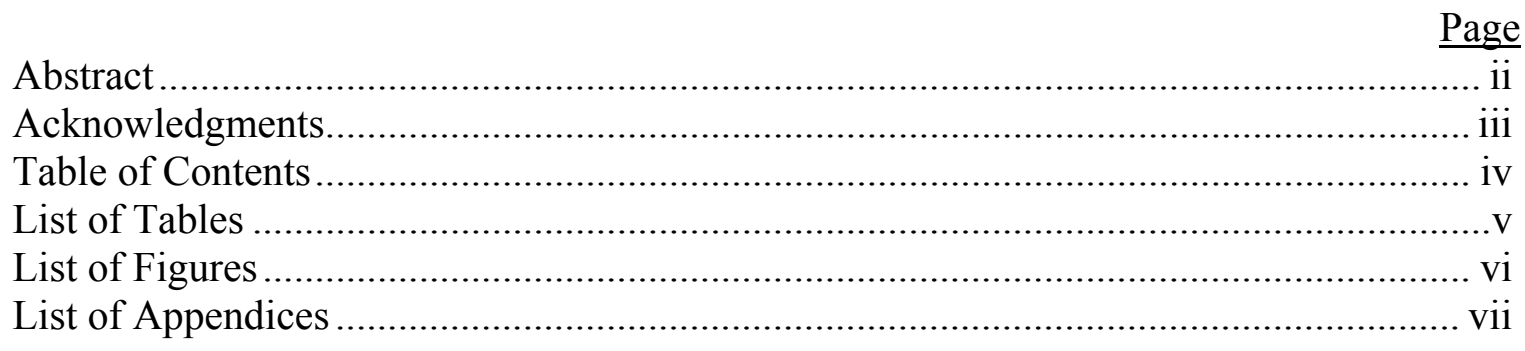

\section{CHAPTER 1: Literature Review of Cerulean Warblers and Canopy Gaps}

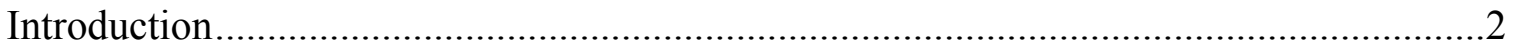

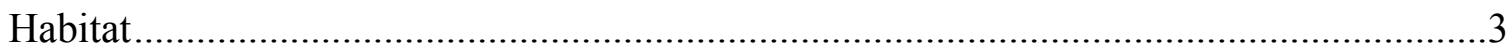

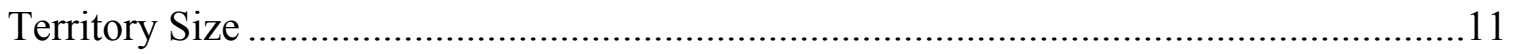

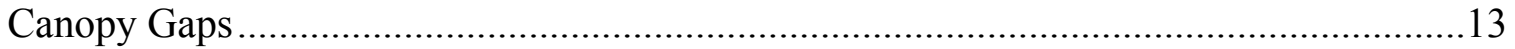

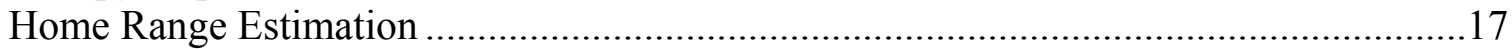

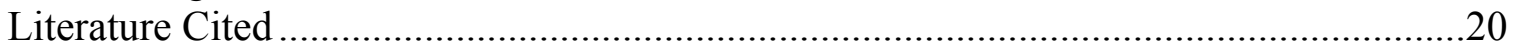

\section{CHAPTER 2: Cerulean Warbler Selection of Forest Canopy Gaps}

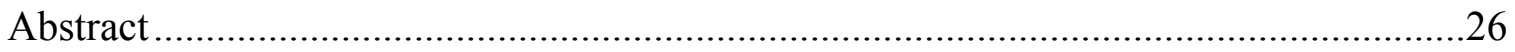

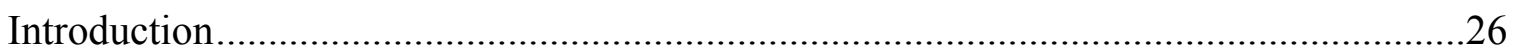

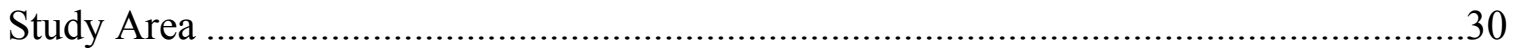

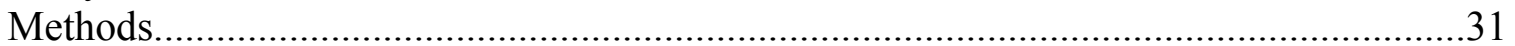

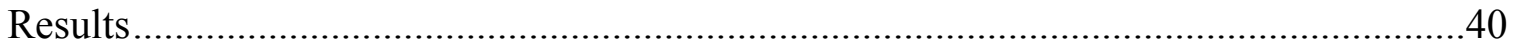

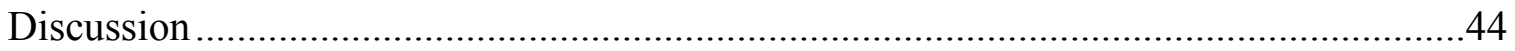

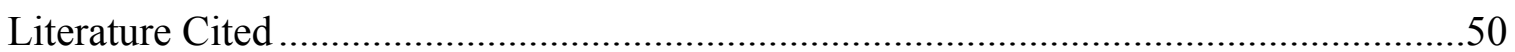

\section{CHAPTER 3: Time Activity Budgets of Cerulean Warblers}

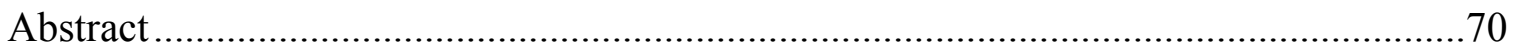

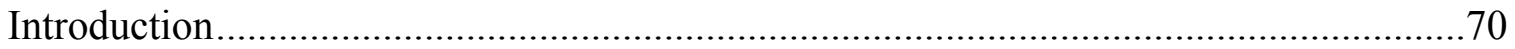

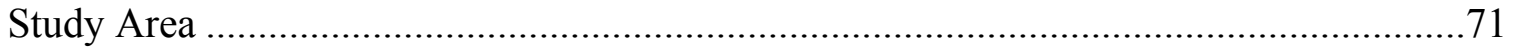

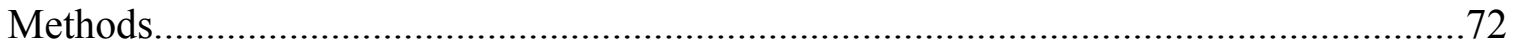

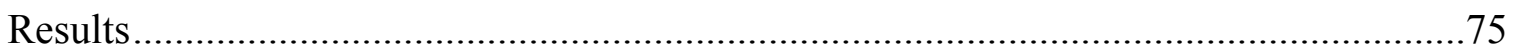

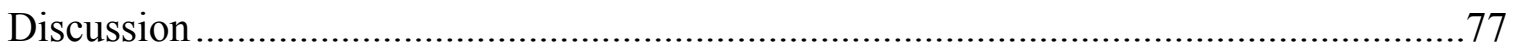

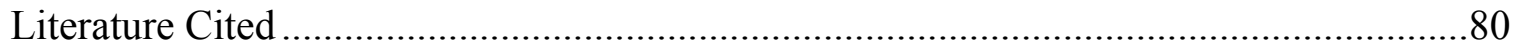




\section{Chapter 2:}

\section{LIST OF TABLES}

Table 1. Types of canopy disturbance present on each study site surveyed for Cerulean Warblers on Lewis Wetzel Wildlife Management Area and the Lantz Farm and Nature Preserve in Wetzel County, WV in 2004 and 2005

Table 2. Two-tailed $t$-test results of summary gap variables on Hart Ridge (HR) and Snake Ridge (SR) sites on Lewis Wetzel Wildlife Management Area in Wetzel County, WV in 2005

Table 3. Results of chi-square analysis of canopy gap characteristics of Cerulean Warbler territories, core areas, and random sampling plots on Snake Ridge (SR) and Hart Ridge (HR) at the Lewis Wetzel Wildlife Management Area in Wetzel County, WV in 2005

Table 4. Mean ( \pm SE and range) territory sizes of Cerulean Warblers in Wetzel County, WV estimated by minimum convex polygon, $95 \%$ fixed kernel methods, and 50\% fixed kernel core area estimates

Table 5. Means ( \pm SE and range) of summary canopy gap variables within Cerulean Warbler territories, core areas, and random sampling plots in Wetzel County, WV

Table 6. Results of linear regression of Cerulean Warbler territory size related to summary gap variables

Table 7. Observed and expected values from chi-square analysis of canopy gap type between gaps located on Cerulean Warbler territory peripheries and those located within territories in Wetzel County, WV in 2005.

Table 8. Observed and expected values of frequency data from chi-square analysis of surrounding gap canopy heights on Snake Ridge in Wetzel County, WV in 2005

Table 9. Observed and expected values of frequency data from chi-square analysis of within gap vegetation heights on Hart Ridge in Wetzel County, WV in 2005.

Table 10. Observed and expected values from chi-square analysis of canopy gap size between gaps located on Cerulean Warbler territory peripheries and those located within territories across all sites by year in Wetzel County, WV

\section{Chapter 3:}

Table 1. Observations of Cerulean Warbler males by activity, vegetative strata, and tree species in Wetzel County, WV collected during morning hours (0600-1130) in May through June 2005 
Table 2. Results of chi-square analysis of Cerulean Warbler observations on the Lewis Wetzel Wildlife Management Area in Wetzel County, WV (May-June 2005).

Table 3. Observed and expected values of chi-square analysis display differences in frequency of observed activities among vegetative strata for Cerulean Warblers on Hart Ridge, located on the Lewis Wetzel Wildlife Management Area in Wetzel County, WV (May-June 2005)

Table 4. Observed and expected values of chi-square analysis indicate that frequency of Cerulean Warbler activities differ from locations within and outside of core areas on two sites in Wetzel County, WV (May-June 2005)..... . .85

Table 5. Observed and expected values of chi-square analysis display differences in frequency of observed activities among vegetative strata for Cerulean Warblers on Hart Ridge (HR) and Snake Ridge (SR), located on Lewis Wetzel Wildlife Management Area in Wetzel County, WV (May-June 2005)

\section{LIST OF FIGURES}

\section{Chapter 2:}

Figure 1. Plot of territory size $\left(\mathrm{m}^{2}\right)$ and canopy gap density $\left(\right.$ per $\left.500 \mathrm{~m}^{2}\right)$ among Cerulean Warbler territories in Wetzel County, WV. Territory sizes were estimated by minimum convex polygons in 2004 and by $95 \%$ fixed kernels in 2005 . Linear regression results were significant in $2004\left(\mathrm{r}^{2}=0.59, \mathrm{~F}=39.64, \mathrm{df}=1, \mathrm{P}=<0.001\right)$ and $2005\left(\mathrm{r}^{2}=0.46, \mathrm{~F}\right.$

$=16.36, \mathrm{df}=1, \mathrm{P}=<0.001)$.

\section{Chapter 3:}

Figure 1. Percent of observations of Cerulean Warbler activities by site in Wetzel County WV, collected May through June in 2005

Figure 2. Percent occurrence of Cerulean Warbler observations among tree species on two sites in Wetzel County, WV, collected May through June 2005

Figure 3. Percent of observations of Cerulean Warblers by vegetative height class on two sites in Wetzel County, WV collected May through June 2005 


\section{LIST OF APPENDICES}

\section{Chapter 2:}

Appendix 1. Canopy gap variables measured in Cerulean Warbler territories and random sampling plots in Wetzel County, WV in 2005

Appendix 2. Example of a Cerulean Warbler territory represented by a 95\% fixed kernel estimate. Dots represent bird locations. Interior open shapes represent the $50 \%$ fixed kernel core area estimate while filled shapes represent canopy gap shapefiles clipped with the $95 \%$ kernel shapefile. The dotted line represents a $5 \mathrm{~m}$ buffer around the territory ....65

Appendix 3. Minimum convex polygon (MCP) territory size estimates of Cerulean Warblers on Lewis Wetzel Wildlife Management Area and Lantz Farm and Nature Preserve in Wetzel County, WV in 2004.

Appendix 4. Territory sizes for Cerulean Warblers on Lewis Wetzel Wildlife Management Area in Wetzel County, WV in 2005. Territory sizes are estimated using minimum convex polygon (MCP) and fixed kernel methods.

Appendix 5. Summary gap variables $(\bar{x} \pm \mathrm{SE})$ for 2004 Cerulean Warbler territories by site on Lewis Wetzel Wildlife Management Area in Wetzel County, WV .....

Appendix 6. Mean ( \pm SE) distances of Cerulean Warbler territories from the nearest large gap or edge in Wetzel County, WV. Multiple territories may occur nearest to the same gap. 


\section{Chapter 1}

\section{Literature Review of Cerulean Warblers and Canopy Gaps}




\section{Introduction}

The Cerulean Warbler (Dendroica cerulea) is a small Neotropical migrant songbird of recent conservation concern. It forages by gleaning insects from leaves and twigs and is often heard before it is seen in the mid to upper portions of large canopy trees (Hamel 2000a). Cerulean Warblers are canopy nesters, with nest heights exceeding $30 \mathrm{~m}$ in the US (Hamel 2000b), making nesting data difficult to obtain. The majority of productivity data comes from breeding populations in Ontario, Canada in the northern extent of their range.

The summer range of the Cerulean Warbler spans a large portion of the eastern deciduous forest; West Virginia occurs within the core of its range (Rosenberg et al. 2000). They overwinter on the eastern slope of the Andes at elevations of 500-2,000m from Columbia to Peru and in the montane forests of Venezuela (Hamel 2000b, Jones et al. 2000). They spend the nonbreeding season in mixed species flocks and have been found in shade-grown coffee plantations in the tropics (Jones et al. 2000).

The Breeding Bird Survey reports that Cerulean Warbler populations have declined at an average of 4\% per year since 1966 resulting in a population reduction of $70 \%$ rangewide, over the monitoring period (Sauer et al. 2003). Habitat loss in both summer and wintering grounds is thought to be a primary cause of this decline (Hamel et al. 2004). Although Cerulean Warblers are expanding their range in the northeast, data suggests that at least some of these areas may be population sinks (Jones et al. 2001). Jones et al. (2004) reported low fecundity levels in Ontario following a destructive ice storm in 1998. The study found that productivity levels were not high enough to compensate for the mortality rates during migration and the overwintering period. A study in southern Indiana also reported low fecundity and suggested that a 20,000 ha largely forested wildlife refuge may also be a population sink (Roth 2004). In response to the long-term population decline, Partners in Flight (PIF), a volunteer organization devoted to the conservation of Neotropical migratory birds and their habitats, has listed the Cerulean Warbler as a species of high concern over most of its breeding range. Cerulean Warblers are currently under consideration by the US Fish and Wildlife Service (USFWS) for listing as a threatened species under the Endangered Species Act and a status assessment to this end was completed in 2000 that compiled the biological data for 
the species to date and identified past, present and future threats to the species (Hamel 2000b). The Cerulean Warbler Atlas Project identified important areas for Cerulean Warblers within their breeding range, breeding status at the locations, and quantified the range of used vegetative habitats (Rosenberg et al. 2002). There is also current research underway into how forest management practices may affect this species. The Cerulean Warbler Technical Group, formed in 2001, developed a common research initiative that spanned multiple states in the core breeding range with the goal of determining how various intensities of timber harvest would affect Cerulean Warbler densities within the harvested and surrounding area. This research is ongoing. Despite the recent attention this species has received, there is still much that is unknown about Cerulean Warbler habitat requirements (Hamel et al. 2004).

\section{Habitat}

Habitat has been defined as the sum of all resources that produce occupancy by a given organism (Hall et al. 1997). This may include not only cover, water and food resources, but also reproductive opportunities, competition, predation and parasitism. The majority of research on Cerulean Warbler habitat has focused on sensitivity to forest tract size, fragmentation and canopy disturbance, vegetative characteristics of nest sites and the surrounding nest patch, forest structure, and canopy architecture.

\section{Landscape-level and Historic Habitat Associations}

Preferred habitat for Cerulean Warblers on the breeding grounds may no longer exist (Hamel 2000b). Historically, they were especially abundant in large tracts of undisturbed mature forest and old-growth bottomland forests of the Mississippi Alluvial Valley and on mesic upland forests in the Ohio Hills (Hamel 2000b). The majority of land in these habitat types has been heavily logged and developed or converted to agricultural lands (Hamel 2000). This may be forcing Cerulean Warblers to use marginal habitat on the breeding grounds where reproductive success is reduced. This poses a challenge to researchers studying habitat selection in this species because available habitat may not be what the species is best adapted to exploit.

The Cerulean Warbler has been classified as an area-sensitive species that prefers mature unfragmented forest (Hamel 2000a). There is evidence that large-scale edge such as those created by mountaintop mining, canopy disturbance, and significant 
fragmentation have a negative effect on this species. Bosworth (2003) examined the effects of large-scale edge created by mountaintop removal mining in southern West Virginia and found that although the species exhibited some tolerance to canopy disturbance, species abundance decreased significantly with distance to mine edge. Robbins et al. (1989) found that Cerulean Warblers generally required forested tracts $>700$ ha. Weakland and Wood (2005) found that intact forests were used more often than fragmented forest with territory densities over six times greater in intact forest in southern West Virginia. Wood et al. (2006) found a correlation between Cerulean Warbler abundances and distances up to $340 \mathrm{~m}$ from mountaintop mine edges indicating that the birds were avoiding large-scale edge.

Weakland and Wood (2005) found, however, that Cerulean Warblers were not avoiding internal edges (i.e. smaller edges such as partially open canopy roads and trails within forested locations). They also found that territories were located next to streams less than expected and that $63 \%$ of territories were located next to roads with patchy overhead canopy cover which was greater than what was expected.

One study documented the effect of a sizeable loss in forest canopy to a Cerulean Warbler population. Jones et al. (2001) monitored a population of Cerulean Warblers before and after a catastrophic ice storm in 1998 that reduced canopy cover at their study site in Ontario by as much as $60 \%$. They found little change in nest site selection the year following the ice storm but did see a significant decline in nesting success. The following year, territory size increased and nests were placed higher in larger (height and dbh) trees. Their study demonstrated that significant reductions in canopy cover can negatively influence reproductive success and alter habitat use.

Cerulean Warblers in West Virginia occur in abundance on dry-slopes and ridgetops (Bosworth 2003, Weakland and Wood 2005, Rosenberg et al. 2000) which contradicts or is potentially misrepresented by historical definitions of Cerulean habitat. They have also been found in younger forests in West Virginia (Wood et al. 2005). Rosenberg et al. (2000) suggested that Cerulean Warblers may be opportunistic in seeking out the mature forest within a region. They also tolerate some level of fragmentation, edge, and canopy disturbance in different parts of their range (Hamel 2000a, Weakland and Wood 2005). Lynch (1981) observed Cerulean Warblers in areas 
where selective logging was taking place in North Carolina and Nichols (1996) reported the species was present in two-aged harvested areas in West Virginia. Cerulean Warblers were found in a previously clearcut stand 16 years post harvest in West Virginia (Wood et al. 2005). Some level of canopy disturbance such as small canopy gaps may even be important to this species. Hunter (2001) reported an affinity for canopy gaps near large trees. Oliarnyk and Robinson (1996) documented nest sites to be within 30m of a canopy gap in Ontario.

Vegetative Associations

Attempting to define Cerulean Warbler habitat by vegetative characteristics continues to pose a challenge to researches. One attempt by Anderson and Shugart (1974) in eastern Tennessee found that Cerulean Warbler habitat could not be characterized by any one of 28 habitat variables that were often correlated with other bird species' distributions. Among the habitat variables measured were average tree dbh, and foliage and branch biomass. One reason for this lack of correlation may be that the range of vegetative types present at the study sites did not exceed the range used by the species (Anderson and Shugart 1974). The Cerulean Warbler Status Assessment reported a tentative conclusion based on the compilation of available nesting data that Cerulean Warblers use a variety of tree species and "do not prefer any particular species or species group across the breeding range, although certain trees or trees of certain crown classes may be frequently used in particular localities" (Hamel 2000b). There has been some success at identifying tree species and vegetative associations at a more local level.

The Cerulean Warbler Atlas project identified tree species used commonly for singing and foraging across USFWS regions 3, 4, and 5. In West Virginia these were most often oaks (Quercus spp.), maples (Acer spp.), and hickories (Carya spp.) (Rosenberg et al. 2000). This identifies only used habitat and not selection or preference because no measure of available tree species was obtained. The Atlas Project also attempted to define Cerulean Warbler use of forest type by categories including riparian/bottomland, dry slope/ridgetop or upland, and mesic slope/cove forest. The primary forest type used was either riparian/bottomland or mesic slope/cove forest for all 3 regions with dry slope/ridgetop or upland forest as the next highest use in each region (Rosenberg et al 2000). 
One study found that $53 \%$ of Cerulean Warbler nests $(\mathrm{N}=43)$ at a wildlife refuge in southern Indiana were in black walnut (Juglans nigra) or white oak (Q. alba) (Roth 2004). There was some evidence that while Cerulean Warblers were mostly using trees in relation to their availability, there were some trees they were not using notably tulip poplar (Liriodendron tulipifera), which was used as a nest tree less than its availability. The study did find a strong relation of Cerulean Warblers and certain aspects of forest structure. Probability of Cerulean Warbler use of forest at the territory level increased with canopy height and decreased with increasing number of trees, which is congruent with previous research indicating that Ceruleans primarily use mature forest (Roth 2004). A study in Ontario also reported the species was selecting territories with large wellspaced trees and dense high canopy (Jones and Robertson 2001). A dense high canopy in forestry terms may translate to a high density of trees in the dominant and codominant crown classes.

One explanation for the lack of vegetative associations may be that Ceruleans are attracted to forest structure, particularly large blocks of mature forest with a dense canopy layer containing vertical structure and gaps, over a particular tree species or vegetative characteristic itself. Another partial explanation may be that Cerulean Warblers exhibit clustering behavior (Hamel 2000a), as some other species of passerines are known to exhibit as well (Stamps 1988, Tarof and Ratcliffe 2004). Newly arriving migrants may select territory locations where other individuals have already established territories instead of seeking out higher quality habitat. Under these circumstances, vegetative characteristics and species of the local area may be used more often than available as an artifact of the clustering behavior and not selection of the vegetative feature itself. Nest Site Characteristics

Nest site characteristics and nest site selection have been studied in populations near Ontario, Canada, in the northern extent of the species' range. Oliarnyk and Robertson (1996) found the majority of nests to be located within 30m of a canopy gap in otherwise contiguous forest and on the outer edge of a lateral branch. They also found nest locations to be in the lower third of the canopy (71\%) and located above an understory gap (59\%). There may be some observer bias in the last two findings because nests lower in the canopy with less vegetation between the forest floor and the nest limb 
would be easier to find. However, this bias is lessened by the high number of nests that were found; 17 nests were found in 15 out of 18 territories.

Jones and Robertson (2001) examined 9 vegetative characteristics of Cerulean Warbler territories, the area surrounding nest sites, and at nest sites. The only significant vegetative difference found between unsuccessful nests and successful renests was greater foliage cover at $6-12 \mathrm{~m}$; cover above $18 \mathrm{~m}$ was also important but was statistically significant for one year only (Jones and Robertson 2001).

Vegetative cover may be important to Cerulean Warblers in nest site selection as well. All nests $(\mathrm{N}=43)$ found during a study in southern Indiana were concealed by either Virginia creeper (Parthenocissus quinquefolia) or nest tree foliage (Roth 2004).

\section{Canopy Architecture}

There is evidence that Cerulean Warblers are attracted to a heterogeneous vertical canopy structure. Lynch (1981) reported a preference for a canopy divided into distinct vertical layers in the flood plain forests of North Carolina. A study in eastern Tennessee reported consistent observation of Cerulean Warblers feeding in the uppermost canopy layers and observed that "it appears to be best typified by its vertical rather than horizontal (habitat) stratification" (Anderson and Shugart 1974). Studies in West Virginia have found the highest abundance of Cerulean Warblers on ridges (Weakland and Wood 2005, Bosworth 2003). Perhaps in some sites the species is responding to the heterogeneous canopy structure provided by a narrow ridge with a vertically stratified canopy on the side-slopes.

Research has yet to determine how much and in what age forest vertical stratification is beneficial to Cerulean Warblers. Adams and Barrett (1976) found Cerulean Warblers were common in an old growth sugar maple (Acer saccarum) -beech (Fagus grandifolia) forest in Ohio, but absent in a mature but younger selectively cut forest $48 \mathrm{~km}$ away. Both forests were sugar maple-beech dominant and similar in site characteristics. The selectively cut site had a more diverse species composition and four separate canopy strata while the old-growth stand had only beech and sugar maple in the canopy and was divided into just two separate strata between these species. Potentially, Cerulean Warblers were selecting the more mature forest in this instance over the heavily stratified canopy in the selectively logged site. It is possible that canopy stratification 
that results in the loss of large trees may be less desirable to Cerulean Warblers especially in lowland sites. Preferred vegetative structure for this species is likely a combination of factors including large tracts of mature forest with large trees, canopy breaks, and canopy stratification. Cerulean Warblers may use forests with at least some of these traits depending on the site.

Previous researchers have suggested that canopy gaps may be an important component of habitat for Cerulean Warblers as well (Hunter 2001, Oliarnyk and Robertson 1996). Canopy gaps may influence the availability of key resources such as prey and desirable nest sites. Treefall gaps provide rich foraging opportunities for many bird species (Noss 1991, and Smith and Dallman 1996). Vegetative structure may be especially important to avian forest species because it affects how birds move and forage and how they can see and capture prey (Robinson 1982). Canopy gaps may be a key resource influencing prey abundance and availability and therefore, may be important in providing quality habitat for Cerulean Warblers.

The importance of canopy gaps to Cerulean Warblers has been noted but not thoroughly researched in previous studies. Oliarnyk and Robinson (1996) documented that nest sites were within $30 \mathrm{~m}$ of a canopy gap in their study site in Ontario. Of a random sample of points within each territory only $23 \%$ were found to be within $30 \mathrm{~m}$ of a gap demonstrating that Cerulean Warblers may be selecting nest sites near a canopy gap. Bosworth (2003) found that Cerulean Warbler presence was positively associated with snags in West Virginia. Weakland and Wood (2005) also found an association between the species' presence and occurrence of snags on ridgetops in southern West Virginia. The correlation between the species presence and snag density is most likely due to increases in insect prey resulting from increased light availability and foliage surrounding the canopy gap or to other benefits such as song projection or a vantage point rather than to the snag itself. Hunter et al. (2001) reported an, "affinity for openings adjacent to the largest trees in a stand, often creating a complex canopy structure." Despite the apparent affinity of Cerulean Warblers for canopy gaps, they are still considered a mature forest species and associations with dense canopy cover at some heights have been found. Bosworth (2003) found a positive association of Cerulean Warbler presence with snags but also with the canopy-cover class greater than $24 \mathrm{~m}$ in 
height. Another study reported Cerulean Warbler association with a dense high canopy (Jones and Robertson 2001). Preferences may exist for a relatively closed or dense canopy with obvious canopy gaps along ridges and side-slopes in West Virginia.

Historical preference for old-growth forest may have been a combination of preference for large trees in a mature canopy and also for the gaps created when trees died, providing growing space and allowing understory trees and seedlings to grow towards the canopy. Mortality of single trees within an older stand reinitiation or oldgrowth stage forest may provide a complex canopy structure and be attractive to birds not only because of gaps themselves but also due to vertical structure provided by new growth.

However, extensive canopy breaks and significant reductions in forest canopy are likely detrimental to this species. Jones et al. (2001) documented Cerulean Warbler habitat use and nesting success in a forest stand in southern Ontario, for four years before, and for two years following a destructive ice storm in January 1998. The storm led to reductions of mean canopy cover as high as $60 \%$. The study found that during the 1998 breeding season there was no change in Cerulean Warbler habitat use and in 1998 and 1999 they showed no preference for areas with lower canopy disturbance. In both years following the storm there was a significant decline in reproductive success. In 1999 however, territory size increased and nests were placed in larger trees (both height and diameter), but in the same vertical location within the tree. There was an increase in reproductive output from 1998 to 1999 but it was still lower than it was prior to the ice storm. Their study documented that considerable loss of forest canopy is harmful to Cerulean Warbler nesting success, but also suggested a level of plasticity in nest site selection in coming years that in part offset the decrease in production. The authors suggested that since there was a one-year time lag in changes in nest site selection after the storm, Cerulean Warblers most likely altered nest site locations to minimize predation and nest failure rather than to avoid canopy disturbance directly. Similarly, Hamel (2000) suggested that Cerulean Warblers avoid large-scale edges and clearings due to declines in nesting success resulting from predation and parasitism, instead of responding to the presence of the edge itself. However, he proposed more research is needed on this topic. It is likely that canopy disturbance and small edges that do not result in an 
increase in nest predation, food shortages, or nest parasitism will not affect productivity and will therefore be tolerated.

Habitat selection for a species may differ among locations throughout its range depending on abundance of key resources. This could explain the apparent dichotomy of Cerulean habitat use in different parts of their range. For example, several studies have cited Cerulean preference for habitat with very large trees and old-growth forest (Hamel 2000a, 2000b). The majority of this habitat description may come from records of Ceruleans in old-growth bottomland forest. Ceruleans in West Virginia have been found in mature but slightly younger forest types and Weakland and Wood (2002) did not find tree diameter to be a predictor of Cerulean occurrence in southern West Virginia. It is possible that canopy structure is such a critical habitat component for Ceruleans that they are responding to the vertical canopy structure provided by the ridgetops in some sites in West Virginia over their preference for more mature forests or forests with larger diameter trees.

It is known that the vegetative characteristics of a habitat may affect productivity and habitat quality. Holmes (1996) found Black-throated Blue Warbler (Dendroica caerulescens) nest success was linked to habitat with dense shrubs. Nesting success of Indigo Buntings (Passerina cyanea) was found to be higher in natural canopy gaps than along abrupt edges such as wildlife openings (Suarez et al. 1996). Duguay et al. (2000) determined Wood Thrush (Hylocichla mustelina) nestling growth rates were higher in unharvested stands which had higher insect abundance than two-age harvests. It is important to identify what features of forest structure may affect the quality of habitat for Cerulean Warblers. Jones et al. (2001) found declines in nesting success and daily survival rate after an ice storm that reduced canopy cover thereby providing lower quality habitat. They hypothesized that the lower reproductive success resulted from the reduction in canopy cover making nests more visible to predators. They also suggested that the reduced reproductive success, in part, could have been due to a potential decrease in insect abundance resulting from damaged canopy trees. Both food abundance and unobtrusive nest site locations may affect reproductive success for Cerulean Warblers. Therefore, the abundance of these resources and the vegetative characteristics that support them are important components of quality Cerulean Warbler habitat. 


\section{Territory Size}

Territory size in passerines is a reflection of body weight (Schoener 1968), energy requirements, and food habits (Gill 1994). Typically a bird will defend as large a territory size as possible until the additional costs of expanding the territory outweighs the benefit gained from that resource (Gill 1994). Food resources are an important factor influencing territory size in birds but also availability of nesting sites (Orians and Wilson 1964) and contender pressure (Hixon 1980, Morse 1976, and Stamps 1990).

Four previous studies have examined Cerulean Warbler territory size, none in a central breeding location in the United States. Jones et al. (2001) documented increases in mean territory size using territory-mapping methods after an ice storm that removed up to $60 \%$ of the canopy in some areas of the study site in Ontario. Olinaryk and Robertson (1996) reported territory sizes of 0.38 to 2.4 ha with a mean of $1.04 \pm 0.16$ ha among 18 Cerulean territories in Ontario using playback to establish territory boundaries. Roth (2004) found a mean territory size of 0.21 ha also using playback methods in southern Indiana. The aforementioned studies all used minimum convex polygons as the method of defining territory boundaries. Barg et al. (2005), however, concluded that using the fixed kernel method to delineate territory boundaries was a better measure of territory size for Ceruleans because it included less unvisited space than those generated using the minimum convex polygon technique. Barg et al. (2005) documented territory sizes to range from 0.23 to 2.21 ha with a mean of $0.96 \pm 0.18$ ha among 14 males using the minimum convex polygon method. Using the fixed kernel method territory size ranged from 0.12 to 2.35 ha with a mean of $0.70 \pm 0.16$ ha.

Territory size has been correlated with habitat quality among birds as well as other animals (Brooker and Rowley 1995, Jones et al. 2001, Siffczyk et al. 2003, Smith and Shugart 1987, and Stenger 1958). Smaller territories in the absence of contender pressure may indicate higher quality habitat (Jones et al. 2001, Smith and Shugart 1987, and Stenger 1958).

Changes in Cerulean territory size in response to habitat quality have been previously documented. Jones (2001) found a significant increase in the size of Cerulean territories following a severe ice storm in 1998; territory density remained constant among years. In $1997(0.63 \pm 0.05 \mathrm{ha}, \mathrm{n}=9)$ and $1998(0.57 \pm 0.05 \mathrm{ha}, \mathrm{n}=13)$ territories 
were relatively small, followed by a significant increase in $1999(1.17 \pm 0.12$ ha, $\mathrm{n}=10)$. Jones et al. found low reproductive success and higher daily mortality rates in 1998 indicating reduced habitat quality post ice storm. In the 1999 breeding season, territory sizes increased accompanied by an increase in production from the previous year. The authors hypothesized that Ceruleans increased territory size in response to the low reproductive success in the 1998 breeding season.

A correlation between territory size and habitat structure has been found in other passerine species as well. Morse (1976) used territory-mapping methods to determine that Black-throated Green Warbler (Dendroica virens) territory sizes differed between red spruce (Picea rubens) and white spruce (P. glauca) habitat. Although prey abundance was equal between the two forest types, the author suggested that the birds were better able to exploit the resources through their foraging strategy in different vegetation depending on site. The distribution of foraging and roosting sites within the habitat influenced home range size of Savannah Sparrows wintering in south Texas (Ginter and Desmond 2005). Siffczyk (2003) found Willow Tits (Parus montanus) in northern Finland expanded their home ranges in response to habitat loss and altered territory use within their home range to compensate for poor quality habitat. Stenger (1958) found a relation between territory size in Ovenbirds and prey abundance in Ontario. She classified vegetation types by abundance of prey for Ovenbirds and found smallest Ovenbird territories in the vegetative classes with the highest prey abundance. A study by Smith and Shugart (1987) in Tennessee produced similar results; smallest territories were found in areas with the greatest prey abundance. Their studies conflict, however, in which vegetation types produced the greatest abundance of prey. Stenger (1958) found prey abundance decreased as canopy height and density increased and shrub and ground-cover decreased. Smith and Shugart (1987) found the opposite. Differences in microclimate, species composition, and chemistry of the forest floor between the sites in Ontario and Tennessee likely produced differences in insect abundance among them. The correlation between territory size and vegetative structure is often an artifact of the abundance of prey or the ability of the bird to exploit prey in that vegetation. In this example, Ovenbirds had smaller territories that required less energy to defend if food, a key resource in quality habitat, was abundant. Among expanses of suitable habitat and in 
the absence of strong contender pressure, territory size can be explored as a measure of the habitat quality provided by key resources.

\section{Canopy Gaps}

Canopy gaps play a significant role in the stand dynamics of understory reinitiation and old-growth stage forest. Gaps allow light in through the forest canopy enabling understory trees to resume active growth. Depending on the size of the gap, light may reach the forest floor altering soil temperature, moisture, and possibly increasing the rate of decomposition of organic matter creating a release of nutrients (Pickett and White 1985). A ratio exists between the measurements of gap diameter and height of surrounding canopy trees and amount of light and soil moisture within the gap (Runkle 1982). The size of the gap influences what herbs may grow on the forest floor as well as whether shade tolerant or intolerant tree species will be favored. Canopy gaps also may be important to forest fauna as well. Insect abundance may be higher in gaps (Blake and Hoppes 1986, Smith and Dallman 1996, and Gorham 2002). Gaps may serve as a site producing soft mast which is a food source to many wildlife species. A variety of forest songbirds are known to use canopy gaps as an important habitat component (Noss 1991, Smith and Dallman 1996, Robinson and Robinson 1999).

Canopy gaps have been defined a number of ways by researchers. Bartemuccci (2002), in a study of gap disturbances in old-growth forests of British Columbia, identified four types of gaps. Developmental gaps are the vertical projection on the ground of an opening in the forest canopy resulting from the death of one or more canopy trees. Edaphic gaps result from topological features. Shrub gaps are maintained by well-established shrub communities and combination gaps are shrub gaps with tree mortality on their periphery. Developmental gaps are thought to be the most important in influencing stand structure and succession (Runkle 1992) and edaphic gaps, which are not generally open to tree establishment and canopy recruitment, may be the least important. Bartemucci (2002) distinguished canopy gaps from interstitial spaces between crowns by the presence of canopy tree mortality or edaphic features. Overhead breaks in the canopy were no longer considered canopy gaps when understory trees reached twothirds the height of canopy trees. Other researchers have defined gaps by simpler methods. Brokaw (1982) defined a canopy gap as a hole of at least $20 \mathrm{~m}^{2}$ that extends 
down through all levels of the canopy to an average height of $2 \mathrm{~m}$ above the ground. Oliarnyk and Robertson (1996) examined Cerulean Warbler nest site characteristics, including the distance of nest sites to canopy gaps, in a study in Ontario. She defined a canopy gap as an abrupt change in the height of the overstory trees to ground level. Fuller (2000), in a study examining the influence of treefall gaps on birds in old-growth stands in Poland, defined a canopy gap as an opening of at least three trees with the longest dimension measuring $40 \mathrm{~m}$.

Generally a break in the forest canopy of less than $5 \mathrm{~m}$ is not considered a canopy gap to researchers (Pickett and White 1985). This may or may not be advantageous in research because it is unclear how much effect smaller gaps, usually caused by single treefall or competition among neighboring trees creating dieback of canopy branches, may have on understory light conditions as well as foraging or attractive canopy structures to invertebrate or vertebrate species. The definition of a canopy gap is largely dependent upon the research question at hand so it is important for researchers to clearly state their definition in the methods section of their study.

\section{Canopy Gaps and Vegetative Regeneration}

Runkle (1982) examined the role of disturbance and gaps in eastern old-growth deciduous forest. He speculates that new gaps occur in old-growth eastern deciduous forest at a rate of every 100 years exposing 1 to $2 \%$ of the forest to new gaps each year. Gaps may be especially important in regeneration in this forest type because light under the canopy may be only 1\% of full sunlight (Canham 1988). A study by Lorimer (1989) went a step further to project stand structure created by gap formation in northern hardwood forests on the Upper Peninsula in Michigan in absence of large disturbances. He projected old-growth forest stands would have a constant rate of gap creation over time resulting in $12 \%$ of the forest occupied by saplings $(0-10 \mathrm{~cm} \mathrm{dbh}), 18 \%$ by pole groups (11-25 cm dbh), $24 \%$ by mature trees $(26-45 \% \mathrm{~cm} \mathrm{dbh})$ and $46 \%$ by large trees $(>46 \mathrm{~cm})$. He projected that $10 \%$ or less of the forest would be occupied by gaps at any given time. This study demonstrates that even in the absence of large disturbances the low rate of gap creation by tree mortality over time in an old-growth forest results in a complex uneven-aged forest with a mosaic of different age gaps. The process of dieback 
of canopy trees and subsequent regeneration in mature forests creates a stratified vertical canopy that may benefit Cerulean Warblers.

Gaps allow forest regeneration to occur and even small gaps may be of importance. Runkle (1982) found that the majority of gaps in one study were filled by height growth of understory trees and not by lateral growth of canopy trees. He concluded that even small gaps in the forest canopy may provide opportunities for regeneration because they were being filled by new growth. Runkle (1982) found even though large gaps had greater light availability for sapling regrowth, they also had a higher portion of the gap taken up by fallen boles, branches, and leaves.

Gap age and size are important in determining species composition and may affect vegetative regrowth differently (Runkle 1998). Runkle (1998) found that in the southern Appalachians most species reached maximum densities in 7-12 years after gap formation. Gap size was found to have a potentially permanent affect on vegetation while gap age was significantly related to the number of stems and species composition only in the beginning of the study (Runkle 1998).

Besides gap size and age, disturbance type may also influence regeneration in gaps. More intense disturbances such as high intensity fire, landslides, and floods may remove all standing trees and destroy the remaining seedbed (Connell 1989). In these instances gaps may be recolonized by an outside seed source and may have a different species composition than a less intense disturbance like a treefall gap.

\section{Vertebrate and Invertebrate Response to Gaps}

Several researchers have examined the influence of canopy gaps on insect abundance and wildlife. These include studies on aerial and ground insect abundance, reptiles and amphibians, and songbirds. Generally researchers have found that increased light level in gaps may create conditions favorable to some species for thermoregulation and increased prey abundance.

There is evidence that flying insects are more active and abundant in gaps. This may be due to warmer microclimates providing habitat that is more conducive to thermoregulation by insects (Smith and Dallman 1996). Blake and Hoppes (1986) found abundance of flying insects in the orders Diptera and Coleoptera were higher in gaps than in forested controls. Gorham (2002) examined aerial insect abundance, specifically 
homopterans (aphids, leafhoppers, cicadas, and scale insects), within canopy gaps compared to interior forest. He found that gaps supported greater abundance and higher morphospecies richness than interior forest in all years of the study. Six morphospecies of homopterans belonging to two families had greater abundance in canopy gaps. Only one morphospecies was more abundant in interior forest and this was only in one year out of a three year study.

In contrast, Kilgo (2005) found that arthropod abundance sampled via foliage clipping was less abundant near gaps and greatest at distances $>100 \mathrm{~m}$ into the forest. However, foliage was only sampled up to $9.1 \mathrm{~m}$ in height which is lower than the average foraging height for Cerulean Warblers. Greenberg and Forrest (2003) found groundoccurring arthropod abundance was negatively affected by canopy gaps. In their study, total arthropod abundance and biomass were significantly higher in forested controls than in intact or salvage logged gaps. Ground-occurring macroarthropods were positively correlated with density, distribution, and diversity of salamanders, ground-foraging neotropical migrants, and game birds, such as Ruffed Grouse and Wild Turkey. They did not, however, have a predictable influence on local distribution of most vertebrate taxa. Greenberg and Forrest (2003) concluded that small treefall gaps will probably not have population level effects on macroarthropods and their vertebrate predators but large scale harvesting could have adverse effects. Similarly, Duguay et al. (2000) found a correlation between litter-dwelling invertebrate biomass and daily nest survival rates of Wood Thrushes (Hylocichla mustelina), which were both higher in unharvested stands.

Some songbird species are gap dependent, requiring small clearings within a forested landscape to live and reproduce. Robinson and Robinson (1999) in a study of the effects of selective logging on forest birds in Illinois found increased abundance of gap dependent species including Hooded Warblers (Wilsonis citrine), Indigo Buntings, White-eyed Vireos (Vireo griseus), and Carolina Wrens (Thryothorus ludovicianus) in single-tree selection and group-selection harvests. Two forest interior species, the Ovenbird and Red-eyed vireo (Vireo olivaceus), decreased in abundance due to timber harvests and three species requiring larger clearings, Blue-winged Warblers (Vermivora pinus), Prairie Warblers (Dendroica discolor), and Yellow-breasted Chats (Icteria virens), were not present at the site. This study highlights the variable effects of 
harvesting practices on migratory bird species. Thus land managers must consider goals related to the management of individual species when planning harvests to promote wildlife habitat.

Several area-sensitive species of forest interior songbirds that require large tracts of contiguous forest also use forest canopy gaps as an important habitat component. Black-throated Green Warblers use habitat with a mosaic of gaps and closed canopy forest although they spend more time foraging in gaps (Smith and Dallman 1996). Canopy gaps may serve as a prime foraging area with dense foliage providing a higher yield of insects per unit of search time (Smith and Dallman 1996). Smith and Dallman (1996) examined gap use by Black-throated Green Warblers in the upper peninsula of Michigan. They found over $50 \%$ of foraging observations on males and females were in gaps while only $25-30 \%$ were in contiguous forest. Besides increased insect abundance, gaps may be attractive to some birds as territory boundaries, a warm location to sing during cold mornings, and because of increased visibility and song projection (Smith and Dallman 1996).

Cerulean Warblers are also thought to use canopy gaps as an important habitat component. Hunter (2001) reported an "affinity for openings adjacent to the largest trees in a stand, often creating a complex canopy structure." Oliarnyk and Robinson (1996) documented nest sites to be within 30m of a canopy gap. Bosworth (2003) found that Cerulean locations were positively associated with snags. The presence of a snag generally indicates a canopy gap. It is likely that birds were responding to the gap and not the snag itself. Weakland and Wood (2002) also found higher densities of snags on ridgetops where Ceruleans were located. Canopy gaps, as well as the vertical structure provided by the gap as understory trees resume active growth, are thought to be attractive to this species and may be a key habitat component.

\section{Home Range Estimation}

\section{Minimum Convex Polygon Method}

The minimum convex polygon (MCP) method is generally seen as a quick and easy method of territory delineation. It is arguably the only current method that is entirely comparable among studies (Harris et al. 1990). The MCP is the smallest area 
polygon that contains all location points; all internal angles are less than 180 degrees

(Worton 1987). One disadvantage to this method occurs when locations far from areas of primary activity are included, resulting in a home range estimate that is too large and includes areas of nonuse. Another disadvantage is sample size biased area estimates. Also, because the MCP is created by simply connecting the outer point locations there is no measure of space use within the boundary of the home range estimate (Worton 1987). Kernel Method

Kernel methods for estimating home range have largely replaced the harmonic mean estimate and are commonly applied in studies that use radio-telemetry to gather large samples of animal locations. Kernel density estimators were first promoted for use as a home range estimate by Worton (1987). Kernel methods are often a better representation of the true home range of an animal because they account for centers of activity and the amount of time spent in areas throughout the home range. Kernel methods are based on the estimation of a utilization distribution (UD) which is the spatial distribution of point locations of an animal over a plane. Both parametric and nonparametric methods have been applied to estimate the UD (Worton 1989). Kernel density estimation has an advantage over some other methods of UD estimation because it is a nonparametric technique and thereby frees the UD estimate from assumptions that data are normally distributed (Worton 1989). Once the UD of an animal is obtained, the home range may be estimated by a probabilistic model. The confidence region $100 \alpha \%$ determines the animal's home range; $\alpha=0.95$ is a common value. Kernel estimates also include the variable $h$, the smoothing parameter, which controls the amount of variation in each component of the estimate and can be varied by the user (Worton 1989). High $h$ values smooth the data more while low values display more variability of the data and result in "choppier" estimates. The fixed kernel method uses a fixed value of $h$ over the entire plane while the adaptive kernel method uses higher values of $h$ in areas with lower concentrations of points and low $h$ values in areas where locations are concentrated. Fixed kernel density estimates are generally recommended because adaptive kernel estimates may overestimate home range size and have higher error associated with their surface estimate (Seaman and Powell 1996). 
The choices of smoothing parameter and software program have been found to have a large effect on the size and shape of kernel home range estimates (Hemson et al. 2005). Variation in $h$ estimates can be extreme enough to complicate or invalidate some inter- and intra- study comparisons (Hemson et al. 2005). Two preferred methods of calculating $h$ in home-range analyses are the reference smoothing factor $\left(h_{r e f}\right)$ and leastsquares cross-validation (LSCV) (Hemson et al. 2005). Optimal bandwidth for multivariate normal distributions has been calculated and was termed $h_{\text {ref }}$ by Worton (1995). Seldom do animal distributions approximate bivariate normal in the field so a nonparametric method is generally preferred. Often, animal distributions exhibit centers of concentrated activity surrounding a feeding site or shelter and in birds may exhibit a clumped distribution of locations surrounding the nest site, favorite singing perches, or territory boundaries. These instances violate the assumption of normality and will result in too large a bandwidth if $h_{\text {ref }}$ is selected as the smoothing parameter (Seaman and Powell 1996). LSCV is a more appropriate technique because it examines multiple bandwidths and returns the $h$ value that minimizes error (Seaman and Powell 1996). This is accomplished by minimizing the squared distance between a fitted surface calculated using all data points in the estimate and the target surface calculated by excluding one data point (Hemson et al. 2005). Seaman and Powell (1996) found little bias when using LSCV to select the smoothing parameter in a study evaluating the accuracy of kernel density estimators and found it to be the best estimator of home range size and shape over other kernel methods. Hemson et al. (2005), however, found LSCV was only consistently successful at deriving values of $h$ at sample sizes less than 100 locations due to failure of LSCV at large sample sizes containing identical or similar locations. Hemson et al. (2005) cautioned against the use of LSCV for larger data sets where multiple repeated observations of the animal at focal sites (dens, leks, roosts, and territorial boundaries etc.) may result in a failure of LSCV to accurately depict the UD. There have been no published attempts to model the recurring use of focal sites by an animal and more research is necessary to determine an appropriate bandwidth selection method for distributions with tightly clumped locations (Gitzen and Millspaugh 2003, Hemson et al. 2005). This is unfortunate for avian biologists attempting to model spatial use by breeding birds where repeated visits to perches, nest sites, and territorial 
boundaries are common. The resulting peaks in the distribution also become problematic at small sample sizes resulting in fragmentation of the UD. However, the fixed kernel method with LSCV is likely still the best available method for modeling space use by breeding passerines and is a much better way to estimate habitat use than the alternative MCP method (Barg et al. 2005).

\section{Literature Cited}

Adams, D. L., and G. W. Barrett. 1976. Stress effects on bird-species diversity within mature forest ecosystems. American Midland Naturalist 46:179-194.

Barg, J. J., J. Jones, and R. J. Robertson. 2005. Describing breeding territories of migratory passerines: Suggestions for sampling, choice of estimator, and delineation of core areas. Journal of Animal Ecology 74:139-149.

Bartemucci, P.D., C. K., Harper, K. A. Wright, E. F. 2002. Gap disturbances in northern oldgrowth forests of British Columbia, Canada. Journal of Vegetation Science 13:685-696.

Blake, J. G., and W. G. Hoppes. 1986. Influence of resource abundance on use of treefall gaps by birds in an isolated woodlot. Auk 103: 328-340.

Bosworth, S. B. 2003. Cerulean Warbler relative abundance and frequency of occurrence relative to large-scale edge. M.S. Thesis, West Virginia University, Morgantown.

Brooker, M., I. Rowley. 1995. The significance of territory size and quality in the mating strategy of the Splendid Fairy-Wren. Journal of Animal Ecology 64:614-627.

Brokaw, N. V. L. 1982. The definition of a treefall gap and its effect on measures of forest dynamics. Biotropica 14:158-160.

Canham, C. D. 1988. Growth and canopy architecture of shade-tolerant trees: Response to canopy gaps. Ecology 69:786-795.

Connell, J. H., 1989. Some processes affecting the species composition in forest gaps. Ecology 70:560-562.

Duguay, J. P., P. B. Wood, G. W. Miller. 2000. Effects of timber harvests on invertebrate biomass and avian nest success. Wildlife Society Bulletin 28:1123-1131.

Fuller, R. J. 2000. Influence of treefall gaps on distributions of breeding birds within interior old-growth stands in Bialowieza Forest, Poland. The Condor 102:267-274.

Gill, F. B. 1994. Ornithology. W. H. Freeman and Co. New York, NY. 
Gitzen, R. A. and J. J. Millspaugh. 2003. Comparison of least-squares cross-validation bandwidth options for kernel home-range estimation. Wildlife Society Bulletin 31:823-831.

Gorham, L .E., S. L. King, B. D. Keeland, S. Mopper. 2002. Effects of canopy gaps and flooding on homopterans in a bottomland hardwood forest. Wetlands 22:541-549.

Greenberg, C. H., T.G. Forrest. 2003. Seasonal abundance of ground-occurring macroarthropods in forest and canopy gaps in the southern Appalachians. Southeastern Naturalist 2:591608.

Hall, L. S., P. R. Krausman, and M. L. Morrison. 1997. The habitat concept and a plea for standard terminology. Wildlife Society Bulletin 25:173-182.

Hamel, P. B. 2000a. Cerulean Warbler (Dendroica cerulea). The Birds of North America, no. 511 (A. Poole and F. Gill, Eds.). The Birds of North America, Inc., Philadelphia, PA.

Hamel, P. B. 2000b. Cerulean Warbler status assessment. United States Fish and Wildlife Service, Fort Snelling, MN.

Hamel, P. B., D. K. Dawson, and P. D. Keyser. 2004. How can we learn more about the Cerulean Warbler (Dendroica cerulea)? Auk 121:7-14.

Harris, S. C., W. J. Cresswell, P. G. Forde, W. J. Trewhella, T. Wollard, and S. Wray. 1990. Home-range analysis using radio-tracking data - a review of problems and techniques particularly as applied to the study of mammals. Mammal Review 20:97-123.

Hemson, G., P. Johnson, A. South, R. Kenward, R. Ripley, and D. MacDonald. 2005. Are kernels the mustard? Data from global positioning system (GPS) collars suggests problems for kernel home-range analyses with least-squares crossvalidation. Journal of Animal Ecology 74:455-463.

Hicks, R. R. 1998. Silviculture of central hardwoods. Pages 185-242 in Ecology and Management of Central Hardwood Forests. John Wiley \& Sons, Inc. New York.

Holmes, R. T., P. P. Marra, T. W. Sherry. 1996. Habitat-specific demography of breeding Black-throated Blue Warblers (Dendroica caerulescens): Implications for population dynamics. Journal of Animal Ecology 65:183-195.

Hunter, W. C., D. A. Buehler, R. A. Canterbury, J. L. Confer, and P. B. Hamel. 2001. Conservation of disturbance-dependent birds in eastern North America. Wildlife Society Bulletin 29:440-455. 
Jones, J., J. J. Barg, T. S. Sillett, M. L. Veit, and R. J. Robertson. 2004. Minimum estimates of survival and population growth for Cerulean Warblers (Dendroica cerulea) breeding in Ontario, Canada. Auk 121:15-22.

Jones, J., R. D. DeByuyn, J. J. Barg, and R. J. Robertson. 2001. Assessing the effects of natural disturbance on a Neotropical migrant songbird. Ecology 82:2628-2635.

Jones, J., P. R. Perazzi, E. H. Carruthers, R.J. Robertson. 2000. Sociality and foraging behavior of the Cerulean Warbler in Venezuelan shade-coffee plantations. Condor 102:958-962.

Jones, J. and R. J. Robertson. 2001. Territory and nest-site selection of Cerulean Warblers in eastern Ontario. Auk 118:727-735.

Kilgo, J. C. 2005. Harvest-related edge effects on prey availability and foraging of Hooded Warblers in a bottomland hardwood forest. Condor 107:627-636.

Lorimer, C. G., and L. E. Frelich. 1994. Natural disturbance regimes in old-growth northern hard-woods. Journal of Forestry 92:33-38.

Lynch, J. M. 1981. Status of the Cerulean Warbler in the Roanoke River basin of North Carolina. Chat 45:29-35.

Morse, D. H. 1976. Variables affecting the density and territory size of breeding spruce wood warblers. Ecology 57:290-301.

Nichols, J. V. 1996. Effects of two-age timber management and clearcutting on songbird density and reproductive success. MS thesis. West Virginia University, Morgantown.

Noss, R. F. 1991. Effects of edge and internal patchiness on avian habitat use in an old growth Florida hammock. Natural Areas Journal 11:34-47.

Oliarnyk, C. J. and R. J. Robertson. 1996. Breeding behavior and reproductive success of Cerulean Warblers in southeastern Ontario. Wilson Bulletin 108:673-684.

Orians, G. H., and M. F. Willson. 1964. Interspecific territories of birds. Ecology 45: 736-745.

Parker III, T. A. 1994. Habitat, behavior, and spring migration of Cerulean Warbler in Belize. American Birds 48:70-75.

Pickett, S.T.A., and P.S. White (eds.). 1985. The Ecology of Natural Disturbance and Patch Dynamics. Academic Press, New York, NY.

Robinson, S. K. and R. T. Holmes. 1982. Foraging behavior of forest birds: The relationships among search tactics, diet, and habitat structure. Ecology 63:1918 -1931 . 
Robinson, W. D. and S. K. Robinson. 1999. Effects of selective logging on forest bird populations in a fragmented landscape. Conservation Biology 13:158-160.

Rosenberg, K. V., S. E. Barker, and R. W. Rohrberg. 2002. An Atlas of Cerulean Warbler Populations-Final Report to USFWS: 1997-2000 Breeding Seasons. Cornell Laboratory of Ornithology, Ithaca, New York.

Roth, K. L. 2004. Cerulean Warbler breeding biology in Big Oaks National Wildlife Refuge, Madison, IN. M.S. thesis, Ball State University, Muncie, IN.

Runkle, J. R. 1982. Patterns of disturbance in some old-growth mesic forests of eastern North America. Ecology 63:1533-1546.

Runkle, J. R. 1992. Guidelines and sample protocol for sampling forest gaps. General Technical Report PNW-GTR-283. U.S. Department of Agriculture Forest Service, Pacific Northwest Research Station, Portland, Oregon, USA.

Runkle, J. R. 1998. Changes in southern Appalachian canopy tree gaps sampled thrice. Ecology. 79:1768-1780.

Seaman, D. E. and Powell R. A. 1996. An evaluation of the accuracy of kernel density estimators for home range analysis. Ecology 77: 2075-2085.

Siffczyk, C., L. Brotons, K. Kangas, M. Orell. 2003. Home range size of willow tits: A response to winter habitat loss. Oecologia 136:635-642.

Smith, R., and M. Dallman. 1996. Forest gap use by breeding Black-throated Green Warblers. Wilson Bulletin 108:588-591.

Smith, T. M., and H. H. Shugart. 1987. Territory size variation in the Ovenbird: The role of habitat structure. Ecology 68:695-704.

Stamps, J. A. 1990. The effect of contender pressure on territory size and overlap in seasonally territorial species. The American Naturalist 135:614-632.

Stenger, J. 1958. Food habits and available food of Ovenbirds in relation to territory size. Auk 75:125-140.

Weakland, C. A., P. B. Wood, W. M. Ford. 2002. Responses of songbirds to diameter limit cutting in the central Appalachians of West Virginia, USA. Forest Ecology and Management 155:115-129.

Weakland, C. A. and P. B. Wood. 2005. Cerulean Warbler (Dendroica cerulea) microhabitat and landscape-level habitat characteristics in southern West Virginia. Auk 122:497-508. 
Wood, P. B., J. P. Duguay, and J. V. Nichols. 2005. Cerulean Warbler use of regenerated clearcut and two-age harvests. Wildlife Society Bulletin 33:851-858.

Wood, P. B., S. B., Bosworth, and R. Dettmers. 2006. Cerulean Warbler abundance and occurrence relative to large-scale edge and habitat characteristics. Condor 108:154-165.

Worton, B. J. 1987. A review of the models of home range for animal movement. Ecological Modeling 38: 277-298.

Worton, B. J. 1989. Kernel methods for estimating the utilization distribution in home range studies. Ecology 70:164-168.

Worton, B. J. 1995. Using Monte-Carlo simulation to evaluate kernel-based home-range estimators. Journal of Wildlife Management 59:794-800. 


\section{Chapter 2}

\section{Cerulean Warbler Selection of Forest Canopy Gaps}

(Formatted in the style of the Auk) 


\begin{abstract}
Forest canopy gaps are thought to be an important component in Cerulean Warbler (Dendroica cerulea) habitat. This study examined the selection of canopy gaps according to gap type, vegetative structure, and size within territories and core areas of territories in north central West Virginia. Territory size was examined as a potential indicator that gaps may provide an important resource. Gap densities were highest within core areas of Cerulean Warbler territories, although they did not differ between territories and random sampling plots. Gap density was inversely related to territory size also indicating that gaps provided an important resource. Some selection of structural characteristics of gaps was found, as well. Within gap vegetation heights of 12-18 m were used more frequently than available within core areas and surrounding gap canopy heights of $>24 \mathrm{~m}$ were used more frequently than available in territories and core areas but these findings were not consistent across sites. Larger gaps such as wildlife food plots were located more often on the periphery of territories while smaller gaps such as treefalls were located more often than expected within territory boundaries. This study provides further evidence that canopy gaps are an important resource to Cerulean Warblers. Forest management practices that create small gaps $\left(<100 \mathrm{~m}^{2}\right)$ within an otherwise dense canopy and encourage forest growth towards an old-growth structure may benefit this species.
\end{abstract}

\title{
INTRODUCTION
}

The Cerulean Warbler (Dendroica cerulea) is a Neotropical migrant songbird of recent conservation concern. The Breeding Bird Survey reports that Cerulean Warbler populations have declined at an average of 4\% per year since 1966 totaling a population reduction of $70 \%$ rangewide, over the monitoring period (Sauer et al. 2003). Habitat loss in both summer and wintering grounds is thought to be a primary cause of this decline (Hamel et al. 2004), although low fecundity has been reported at least in some portions of their range (Jones et al. 2001, Roth 2004). In response to the long-term population decline, Partners in Flight (PIF), a volunteer organization devoted to the perpetuation of Neotropical migratory birds and their habitats, has listed the Cerulean Warbler as a species of high concern over most of its breeding range. Cerulean Warblers are also currently under consideration by the US Fish and Wildlife Service (USFWS) for listing 
as a threatened species under the Endangered Species Act (Hamel 2000b). However, despite the recent attention this species has received, there is still much that is unknown about Cerulean Warbler habitat requirements (Hamel et al. 2004).

Past research suggests that canopy gaps may be an important resource to Cerulean Warblers (Oliarnyk and Robertson 1996, Hunter 2001, Bosworth 2003, Weakland and Wood 2005, Wood et al. 2006) but this topic has not been explicitly researched. Hamel (2000b), identified research into preferred vegetative structure including the "vertical distribution of vegetation and the horizontal distribution of canopy gaps" as a high priority research need for this species. Gaps may serve as ideal locations for singing perches (Barg 2002), and influence the availability of key resources for passerines such as insect prey (Blake and Hoppes 1986, Noss 1991, Smith and Dallman 1996, and Gorham 2002) and desirable nest sites (Oliarnyk and Robertson 1996). Gaps may be attractive to some birds as territory boundaries, a warm location to sing during cold mornings, and because of increased visibility and song projection (Smith and Dallman 1996).

Hunter et al. (2001) reported the species as having an, "affinity for openings adjacent to the largest trees in a stand, often creating a complex canopy structure." Oliarnyk and Robinson (1996) documented that nest sites were within $30 \mathrm{~m}$ of a canopy gap in their study site in Ontario. Of a random sample of points within each territory only $23 \%$ were found to be within $30 \mathrm{~m}$ of a gap demonstrating that Cerulean Warblers may be selecting nest sites near a canopy gap. Bosworth (2003) found that Cerulean Warbler presence was positively associated with snags in West Virginia. Weakland and Wood (2005) also found an association between the species' presence and occurrence of snags on ridgetops in southern West Virginia, which is likely a reflection of their association with gaps.

If gaps do provide a critical resource for this species then this has implications for the management of forested lands for Cerulean Warblers. Since forests in West Virginia are primarily second-growth, they may lack the density or structure of gaps found in forests approaching the old-growth stage, and the creation of small canopy gaps may be beneficial to this species. Also, if the birds are selecting certain sizes of gaps, land managers may be able to improve habitat through low intensity harvests creating gaps 
within the selected size classes. The opposite is also true, if larger gaps are avoided by Cerulean Warblers, limiting the creation of these gaps may be beneficial to the species as well.

The Cerulean Warbler has been classified as an area sensitive species that prefers mature unfragmented forest (Hamel 2000a). There is evidence that large-scale edges, canopy disturbance, and significant fragmentation have a negative effect on this species (Robbins et al. 1989, Jones et al. 2001, Weakland and Wood 2005, Wood et al. 2006). Cerulean Warbler abundances in West Virginia were negatively affected by large-scale edge created by mountaintop removal mining at distances up to $340 \mathrm{~m}$ from the mine (Bosworth 2003, Weakland and Wood 2005, Wood et al. 2006). Weakland and Wood (2005) found, however, that Cerulean Warblers were not avoiding internal edges (i.e. partially open canopy roads and trails within forested locations). They also found that territories were located next to streams less than expected and that $63 \%$ of territories were located next to roads with patchy overhead canopy cover which was greater than what was expected. There is still question as to what scale of edge or sizes of openings this species may tolerate within a largely contiguous forest.

A canopy gap is defined in this study as a break in the forest canopy at least $5 \mathrm{~m}$ in longest diameter with at least $7 \mathrm{~m}$ down to the next vegetative strata. The criteria of a minimum of $5 \mathrm{~m}$ diameter was chosen because of the time constraints and error involved in mapping numerous small canopy breaks, especially in instances where there was a dense understory layer within the gap and also because this has been the smallest diameter used in previous research to define a gap (Pickett and White 1985). I chose to include gaps that had tall vegetative strata within them because for a canopy associated species, canopy openings between crowns would likely be as valuable as a gap that reaches the forest floor. I chose the $7 \mathrm{~m}$ criteria between strata because it was a large enough difference that observers could consistently visually estimate from the ground. This study identifies the types of gaps that are used by Ceruleans on our study site and estimates within gap vegetative heights and surrounding gap canopy heights. By precisely defining what is meant by the term "canopy gap" and further classifying gaps within Cerulean territories according to type and vegetative structure, this study augments previous knowledge and more accurately describes Cerulean use of forest gaps. 
Territory sizes in birds have been shown to reflect resource abundance. Certain vegetative structures may provide higher quality habitat for many avian species by increasing vegetative substrate for invertebrates and consequently increasing prey abundance or availability. Smaller territory sizes have been linked to vegetative structures providing the highest resource abundances while lesser quality habitats produce larger territories (Brooker and Rowley 1995, Morse 1976, Siffczyk et al. 2003, Smith and Shugart 1987, Stenger 1958). Significant increases in territory sizes have been documented for Cerulean Warblers in response to reduced habitat quality. Following an ice storm that reduced canopy cover at a site in Ontario by as much as $60 \%$, declines in reproductive success and increases in daily mortality rate were reported (Jones et al. 2001). Increases in territory size followed after a one year time-lag demonstrating that territory size in Cerulean Warblers is affected by habitat quality.

My study examined Cerulean Warbler selection and use of forest canopy gaps within territories and core areas. In 2004 territory-mapping methods focusing on mapping territory boundaries and Minimum Convex Polygons (MCPs) were used to define territory boundaries. In 2005 burst sampling methods following Barg et al. (2005) were used in conjunction with fixed kernel methods of home range estimation to delineate territories and core areas. Gap availability among random sampling plots was also measured in 2005.

The specific objectives of this study were to:

1. Determine what types and sizes of gaps Cerulean Warblers include within their territories.

$\mathrm{H}_{1}$ : Cerulean Warblers will include small canopy gaps such as treefall gaps within their territories.

$\mathrm{H}_{2}$ : The species will tolerate some edges such as trails that retain at least partial canopy cover within their territory or on the periphery of the territory.

$\mathrm{H}_{3}$ : Cerulean Warblers will not include larger edges and clearings such as wildlife foodplots, open-canopy roads, or power-lines within their territories.

2. Determine selection of gaps according to type, size, and vegetative structure within territories and core areas.

$\mathrm{H}_{1}$ : Cerulean Warblers will select treefall gaps and smaller gaps more frequently than available and will select larger gaps less frequently than available. 
$\mathrm{H}_{2}$ : Some selection of vegetative characteristics will occur within territories or core areas.

3. Determine if gap density, total gap area, average gap size, or perimeter amounts differ between territories, core areas, and available habitat.

$\mathrm{H}_{1}$ : Cerulean Warblers will include higher gap densities within territories and core areas.

$\mathrm{H}_{2}$ : Total gap area amounts will be lower within territories and core areas than in available habitat.

4. Determine if territory size is related to gap density, total gap area, or perimeter amount.

$\mathrm{H}_{1}$ : Territory sizes will be smaller in areas with high gap densities and larger in areas where total gap area within the territory is high.

5. Determine if distances of territories to large gaps and edge are related to gap type or area.

$\mathrm{H}_{1}$ : Distances of Cerulean Warbler territories will be farthest from the largest gaps and edge regardless of type.

\section{STUDY AREA}

The study area, Lewis Wetzel Wildlife Management Area (LW), located in Wetzel County near Jacksonburg, WV, was 5,418 ha in size with elevations ranging from $224-476 \mathrm{~m}$. The area was predominantly mature forest except for three clearcuts harvested in 1996 and 1997. Other canopy breaks included roads, hunter access trails, gas lines, mowed areas for wildlife food plots, and maintained corridors surrounding powerlines. The 220 ha Lantz Farm and Nature Preserve owned by Wheeling Jesuit University was located adjacent to Lewis Wetzel and included two of the sites surveyed in 2004.

I selected seven sites within the study area that represented different types and sizes of canopy disturbance. All sites had autogenic treefall disturbance while six of seven sites had anthropogenic canopy disturbance (Table 1). Snake Ridge and Outer Ridge had only autogenic treefall disturbance with no recent human-induced canopy disturbance. Multiple types of disturbances occurred on many sites while some sites had disturbances that were unique. One common disturbance that occurred on five of seven sites was partially-open canopy access trails (trails that perforate a relatively closed canopy forest with some canopy openings) running along ridgetops. Major canopy breaks resulting from powerlines crossing the ridgetop occurred at two sites. Two sites had maintained clearings for wildlife food plots or around gas wells with a minimal shrub 
layer. Several sites had clearings with a dense shrub layer where grapevine was impeding succession. The site selected on the Lantz Farm was subject to an 18 ha $40-\mathrm{cm}$ diameter-limit harvest in 1999. The Owlshead site, located partially on the Lantz Farm property and partially on property owned by the Outlaw Hunt Club, was comprised of 67 ha of late-stage mature forest last harvested in the early 1900s by a selection cut. Canopy disturbances at this site included an open canopy powerline that bisected the ridge and an ATV trail that ran along the ridgeline and turned into a trail near the top of the ridge but was mostly closed canopy. Open-canopy is defined as having no overhead canopy cover.

There is some debate over whether the portion of West Virginia from the northern panhandle spanning west along the Ohio south to Parkersburg, including the study site, is classified as mixed mesophytic or Appalachian oak forest. Braun classifies it as the former while Küchler classifies it as the latter (Martin et al. 1993). High levels of diversity characterize both forest types. Norris (1978) reported in an unpublished survey of the Lewis Wetzel Public Hunting Area that the forest was mixed mesophytic in character. Common species were beech (Fagus grandifolia), sugar maple (Acer saccarum), red oak (Quercus rubra), yellow-poplar (Liriodendron tulipifera), and white ash (Fraxinus americana). However in 1910, when Brooks surveyed an 800ha "virgin forest" in the southern portion of Wetzel County the primary species encountered were yellow-poplar and red oak, but also white oak (Q.alba) and chestnut oak (Q. prinus) (Stephenson et al. 1993). All the above mentioned species were found at sites on Lewis Wetzel and Lantz Farm during the study period with the addition of scarlet oak $(Q$. coccinea), black oak (Q. velutina), basswood (Tilia Americana) and several species of hickory (Carya spp.). Beech was found on some sites although, with the exception of Owlshead, was not a commonly occurring species. White oak was present on some sites but in sparse numbers. Elm (Ulmus spp.), black cherry (Prunus serotina) and black locust (Robinia pseudoacacia) were found frequently on the Hart Ridge site.

\section{METHODS}

In late April to early May 2004, I surveyed ridges on LW and Lantz Farm for Cerulean Warblers. I selected seven sites that were accessible, had moderate to high Cerulean abundance, and had variation in types and sizes of canopy disturbance. Ridges 
were surveyed due to past research demonstrating that Ceruleans use side-slopes and ridgetops more often than riparian and bottomland forest in West Virginia (Bosworth 2003, Rosenberg et al. 2000, and Weakland and Wood 2005).

From mid-May to late June 2004, the selected ridges were visited weekly to identify Cerulean territory locations. Six visits were made to each site. This number was selected due to time constraints because Cerulean Warblers stopped singing strongly by the end of June and because at least five visits are considered adequate to define territories when spot-mapping for a single species (Bibby et al. 2000). Territories were marked for each Cerulean Warbler male by flagging trees where the bird was perched. If the bird flew when approached, or could not be seen, the tree where it was last heard was flagged. Territorial boundaries between aggressively counter-singing or sparing males were marked with a different color flagging when encountered. On some occasions males would fly in response to the observer's approach of the tree where they were singing. Because passerines are reluctant to leave territories when "chased" by an observer, potential territory boundaries also were uniquely flagged when this behavior was detected. Observers tried to spend equal amounts of time with each bird on the ridge they were surveying each day and attempted to put up 3 territory flags per bird per day (range 0-6), although this criteria was met depending on how often the bird moved and if it was conspicuous and singing that day. Time spent in each territory was recorded to also ensure that equal time was spent following each bird. Territories with fewer flags were revisited and more time was spent with these birds later in the season to attempt to better define the territory.

Previous researchers have measured territory size in a number of ways. One method is spot-mapping which requires walking a grid and recording observations of a bird and territorial cues on a map of the site (Jones et al. 2001 and Morse 1976). The method used in my study is more rigorous than standard spot-mapping techniques because more time is spent observing the bird in the field allowing the observer to become better acquainted with each bird's territory. In standard spot-mapping, observers record the location of birds on a map while walking transects on a grid through the study area. Observers may pause along the route but they do not follow the birds to map the territory in this manner. While spot-mapping is more efficient for mapping multiple 
species, the method I used in my study allowed observers to spend more of their time observing an individual bird's use of the its territory. In spot-mapping, a minimum of 2 to 3 locations and five visits to each plot are adequate to define a territory for a single species (Bibby et al. 2000). Methods for my study included six visits to each site and a minimum of six observed locations. Spot-mapping relies heavily on the presence of counter-singing males and territorial conflicts to establish territory boundaries. I used these cues as well as the response of the bird fleeing from the observer as a third cue to predict a territory boundary.

In July and August, GPS coordinates were obtained for all flagged locations of singing trees as well as territory boundaries with Trimble GeoExplorer CE series GPS units. Coordinate locations were corrected using data provided by the CORS National Geodetic Survey base station in McConnelsville, OH using GPS Pathfinder software. Accuracy of corrected GPS points was between $0.6-9.0 \mathrm{~m}$ with most points accurate to at least $3 \mathrm{~m}$. Points on ridgetops were accurate to between $0.5-1.5 \mathrm{~m}$. Topography as well as dense canopy on some side-slopes in the management area made it difficult to obtain Trimble readings more accurate than $6 \mathrm{~m}$, even when more than 200 points were logged.

The territories that were delineated by a sufficient number of locations to be used in the gap analysis had between five and 18 flags $(\bar{x}=9)$, were put up over at least three visits, and had at least six observations of the bird at the flagged locations. Smaller territories required fewer than nine flags to mark boundaries and some territories had multiple observations in trees that were previously flagged. Some territories that met the requirements of six flags over three visits were omitted because the bird was observed flying in from a location outside the delineated boundary, or it was otherwise known to the observer that the territory boundary was not adequately established. Well-defined territories were revisited in August to quantify and measure gaps in the overhead canopy.

All canopy gaps beginning within $5 \mathrm{~m}$ of the edge of a territory were mapped. Canopy gap locations for smaller gaps were determined by taking GPS coordinates while larger clearings and edge such as roads, power-lines, and trails were digitized from aerial photographs. Canopy gap size was determined from GPS coordinates of canopy gap edges. Trimble GPS Units were used to record locations of gap edges and 1 to 6 points were taken for different sizes and shapes of gaps. I defined a gap as a break in the 
canopy at least $5 \mathrm{~m}$ in diameter (Pickett and White 1985) across the broadest width and with a distance of at least $7 \mathrm{~m}$ down to the next vegetative strata. GPS accuracy made it difficult to obtain gap edges for smaller gaps. For small circular gaps close to $5 \mathrm{~m}$ in diameter, a single point was taken at the center of the gap. For very long narrow gaps two edge points defined the lengthwise boundary as well as 1 to 3 points bisecting the middle. The width was visually estimated. Two points were used to define lengthwise extents of small-oval shaped gaps. Three points were used to define triangular shaped gaps. Larger gaps were defined with points at the greatest length and width; a point also was taken at obvious corners where the edge of the gap changed direction. Points taken along the perimeter defined all other gaps. All gaps were sketched in field notebooks including estimates of width where appropriate and an indication of where GPS points were taken to assist in locating gaps on aerial photographs. Gap types were recorded as the following categories: trail, treefall/unknown, grapevine impeded, food plot, or diameter-limit cut (Table 1). There were no instances of a powerline or gaswell clearing occurring in or adjacent to a territory, although they were present on the site.

Because there is little reproductive information available for this species, we attempted to monitor nests found over the breeding season. Typical nesting heights of $11.4 \mathrm{~m}$ (Hamel 2000a) made finding and monitoring nests a challenge. We were not able to check nests for contents with a mirror pole due to their height. Instead, we observed nests from the ground using a spotting scope or binoculars to determine nesting stage. Fledglings are evident and vocal the day after fledging and Cerulean Warbler fledglings and adults are known to be active in the area for 1 to 2 weeks after the fledging date (Jones et al. 2001a). We attempted to count fledglings in this manner but the number of fledglings observed and active nests found were inadequate to assess productivity for the birds in any of the study areas.

For the 2005 breeding season, methods were modified to obtain more observed locations of each bird to attain a more accurate estimate of territory size. Two sites were chosen to implement the new methods. Hart Ridge (15 ha) was selected due to the abundance of birds and variety of canopy disturbances and Snake Ridge (7 ha) was selected due to the absence of recent anthropogenic disturbances and abundance of Ceruleans. Using methods of Barg et al. (2005), we collected Cerulean locations in 
sampling bursts rather than by sequential sampling to maximize the number of points taken over a short period of time. For each sampling burst, a male Cerulean Warbler was followed for 30 minutes every three to five days and a GPS location was collected every minute. A time delay of two minutes preceded recording locations in order to reduce bias towards conspicuous sites. If a bird was lost during the 30 minute sampling period each minute it was missing was recorded as a lost data point. At least eight flags or fifteen minutes observing the bird within a 30 minute period was used as the minimum number of locations required for a survey.

In July and August of 2005, territories were mapped for canopy gaps with adjusted methods to expedite the mapping process. To achieve better estimates of gap area, only one GPS location was obtained in the center of smaller gaps and gap dimensions were obtained with a range finder. Dimensions of oval-shaped gaps were obtained by two field workers taking a distance measurement standing across from one another at the edges of the gap using a range finder with receiving panel. Only length and width dimensions were taken for most gaps but more measurements were needed to accurately depict oddly shaped gaps. A compass bearing was taken across the longest length of the gap. Sketches were drawn of any gaps that did not fit a typical oval shape or had extra dimensions taken to aid in digitizing. Multiple GPS locations were taken along the edges of larger gaps where the range finder would not reach or where there was a dense understory. Canopy height surrounding the gap and the vegetation height within the gap was visually estimated by trained field technicians and recorded as one of the following categories: 0-3 m, >3-6 m, >6-12 m, >12-18 m, >18-24 m, and $>24 \mathrm{~m}$. The type of gap was also recorded. Locations of larger clearings and edges such as the food plots on Hart Ridge were digitized from the aerial photographs.

To estimate density, type, perimeter amounts and size of gaps and edge available at each site, stratified randomly selected plots within the delineated study area were ground-truthed for canopy gaps by the same methods. Random sampling plots were equal in size to the mean territory size of birds mapped on Hart Ridge $\left(2204.7 \mathrm{~m}^{2}\right)$ and Snake Ridge $\left(2461.4 \mathrm{~m}^{2}\right)$ in 2005. 


\section{GIS Methods}

I used ArcGIS 9.0 software to obtain all area and distance estimates used in the analyses. Canopy gaps were digitized using field sketches and GPS points of bird locations overlaid on 2003 DOQQs in UTM NAD83 State Plane West Virginia north. Shapefiles of canopy gaps were created in ArcGIS 9.0 using a combination of field sketches, dimensions, and GPS points. I used the arc tool in edit mode in ArcGIS to draw oddly shaped gaps. I used the ellipse tool, available as a sample download from the ArcObjects developer's website, to create oval-shaped gaps in instances where gap dimensions were obtained by taking GPS points of gap edges. To do this, I used the point-distance tool to orient the gap along the correct bearing, dimensions were drawn in with two perpendicular lines, the ellipse was overlaid on a central location, and the edges expanded until the correct dimensions were obtained. For smaller gaps where only a central point and gap dimensions were obtained, I used a program written in ArcView 3.2 by Jackie Strager in 2005, that created ellipse shapefiles from the center coordinates, bearing, and dimensions of the gap. All territory size estimates and gap area calculations were planar and did not account for changes in topography over the site.

Territory sizes in 2004 were estimated using the minimum convex polygon (MCP) method (Jones et al. 2001 and Mohr 1947) and were created using CALHOME software. Fixed kernel methods (Barg et al. 2005 and Worton 1987) were used to estimate territories for the 2005 data and were created using the Animal Movements extension in ArcView 3.2 and the least-squares cross-validation method to determine the smoothing parameter.

The size of individual gaps and gap density were calculated from the gap shapefiles in ArcGIS 9.0. As long as any part of the gap occurred within the territory boundary it was included in the gap density estimate. All gap density and perimeter estimates are reported as the value per $500 \mathrm{~m}^{2}$ of territory (Appendix 1). I calculated the total gap area within the territory by merging all gaps associated with a territory into one shapefile and clipping it with the $95 \%$ kernel estimate for 2005 data and with the MCP boundary for the 2004 data (Appendix 2). The same was done for the total gap area estimate within the core area by using the $50 \%$ kernel density isopleth. All gap estimates obtained for 2005 territories were also calculated for the random sampling plots as well. 
Total gap area calculations for the random sampling plots were calculated by clipping the gap shapefiles with the circular boundary of the plot. The mean gap size was also calculated for territories, core areas, and random sampling plots for the 2005 data and included all gaps that were at least partially located within the boundary.

There were some occasions where the boundary of the gap was not mapped in the field because it continued well outside the territory and in some cases off of the study site. In these instances, this was recorded and the gap was mapped to well outside the territory boundary. These gaps were left out of all analyses that included area measurements of individual gaps.

I calculated gap perimeter by clipping the merged gap shapefile by the plot or territory boundary to obtain a perimeter calculation for the entire gap shapefile. The clipped edges that previously crossed the territory boundary and now followed the boundary line were then subtracted from this calculation to obtain the amount of gap perimeter that occurred within the territory boundary. To accomplish this, Xtools (DeLaune 2005) in ArcGIS was used to first convert all territory shapefiles from polygons to polylines. The "sum line lengths in polygon" tool from Hawth's Tool's (Beyer 2004) was used to obtain the measurement of the clipped edge of the shapefile that touched the territory boundary but was not actually edge. In this procedure, the polyline version of the territory boundary was identified as the line and the merged gap shapefile as the polygon.

I used GIS to determine the locations of gaps relative to the territory boundary. A gap was considered on the periphery of the territory if less than $25 \%$ of the gap area was contained within the territory. Gaps not touching the territory but with an edge located within a $5 \mathrm{~m}$ buffer of the $95 \%$ kernel estimate were also included as periphery gaps (Appendix 2). A gap was considered a "within territory gap" if greater than $25 \%$ of the gap occurred within the $95 \%$ kernel isopleth for the 2005 territories and within the MCP boundary for 2004 data.

I used the measuring tool in ArcGIS 9.0 to obtain distance measurements of each territory to the nearest large gap that was visible on the aerial photograph. The smallest large gap identified near a territory from the aerial photographs was greater than $1700 \mathrm{~m}^{2}$ in area. For each large gap, distances were measured from the closest observed bird 
location of each territory to the nearest edge of the gap. I digitized the gaps from the aerial photographs and calculated gap area for each of them. The gap type (powerline/road, food plot, large grapevine impeded clearing, or opening caused by diameter-limit harvest) was also recorded from the aerial photograph or from knowledge of the field site. For linear gaps such as powerlines and roads that continued for miles, no gap area estimates were calculated and these gaps were omitted from the analysis relating territory distance to gap area.

\section{Statistical Analyses}

I tested raw data and regression residuals for a Gaussian distribution in SAS using proc univariate prior to data analysis. Territory size was log transformed for 2004 data and square route transformed for 2005 data to obtain normal distributions. For 2005 data, average perimeter amount per $500 \mathrm{~m}^{2}$ was square route transformed for Snake Ridge and average gap size was square route transformed for available plots on Snake Ridge to obtain normal distributions. For the distance to large gap calculations the variable, distance to gap, was square route transformed and large gap area was log transformed to obtain normal distributions prior to analysis. All statistical tests used the transformed variables while all values reported in tables are untransformed.

All analyses were tested separately between years because methods differed between years, except for the analysis of distance from the territory to largest gap. Data was pooled between years for this test because no large gaps were created on the study site between 2004 and the 2005 breeding season and because measurements were taken from a single bird location per territory nearest to the gap and not the from MCP or kernel territory itself. I used SAS statistical software V8 for all analyses except $t$-tests, and an alpha value of 0.05 for all statistical tests.

I used student's two-tailed $t$-tests assuming unequal variances in Microsoft Excel in separate analyses, to test if the summary gap variables (gap density, average gap size, gap perimeter, and total gap area) (Appendix 1) differed among HR and SR sites, between territories and available habitat, between core areas and territories, and between core areas and available habitat (Table 2). Total gap area was calculated as the sum area of the portions of all gaps that lay within the territory boundary divided by the territory size and was reported as a percentage in all tables. Gap perimeter was not calculated or 
tested within the core areas because of the limitations of accurately mapping this parameter within these smaller regions. I used linear regression to determine if the gap density, gap perimeter, or total gap area was related to territory size.

I used analysis of covariance (ANCOVA) to examine if gap type and gap size were related to the distance of territories to large gaps. For this test, distance was the independent variable, gap type was a dependent variable, and gap size was a covariate.

I used Pearson chi-square tests of homogeneity to determine if the frequency of the gap variables (gap type, gap size category, vegetation height category, and canopy height category) from 2005 data differed from expected between the territories and available habitat, core areas and available habitat, and territories and core areas (Table 3). I made gap area a categorical variable for purposes of chi-square analysis by placing each gap into one of the following categories: $<100 \mathrm{~m}^{2}, 101-250 \mathrm{~m}^{2}, 251-500 \mathrm{~m}^{2}$, or $>501 \mathrm{~m}^{2}$. Chi-square tests were also used to determine if any of the categorical gap variables from 2005 and if gap type or area in 2004 occurred more frequently than expected on the periphery of the territory compared to the gaps that were located within the territory boundary. For all chi-square analyses, canopy height and within gap vegetation height were tested separately between sites in 2005 because these parameters differed between the two ridges and resulted in different outcomes of the test. There was not a large enough sample size of gaps on Snake Ridge to test whether canopy height or vegetation height differed among gaps located in the territory and gaps on the periphery of the territory. Gap type was tested separately for the two ridges and later pooled because results were similar on both sites and it is unlikely that the same type of gap would be used differently between the study areas. In 2004, gap type and area were also analyzed across all sites combined. In 2004 grapevine impeded gaps were pooled with treefall gaps in the chi-square analysis because there was not a large enough sample size of this type of gap for a valid test and the two gap types were similar in structure. Gaps resulting from a diameter-limit harvest were included in chi-square analysis of gap type in 2004 but were not present on surveyed sites in 2005 .

I calculated standardized residuals for all cells in chi-square tests with significant outcomes by the equation [(observed-expected)/square root expected] (Reynolds 1977, Newman and Waters 1984, Smith and Iverson 2004). The farther the value of the 
standardized residual was from zero, the more important the difference between the observed and expected cell value was to the outcome of the test. Values greater than \pm 1 , especially those approaching \pm 2 , are considered important while values near zero indicate little difference between observed and expected values (Acastat Handbook 2004, Smith and Iverson 2004).

\section{RESULTS}

In 2004, 98 Cerulean Warbler territories were found on Lewis Wetzel and the adjacent Lantz Farm. Thirty territories over seven sites had enough locations and days visited to meet the criteria to be included in the territory size analysis. Of these, 1 territory was omitted from the gap analysis due to limitations in estimating gap number and area within that territory. The number of flags defining each territory ranged from 5 to $18(\bar{x}=9)$ with at least six observations of the bird over the flagged locations (Appendix 3). Neither the number of flags $\left(\mathrm{r}^{2}=0.11, \mathrm{df}=1, P=0.07\right)$ nor the number of bird observations $\left(\mathrm{r}^{2}=0.09, \mathrm{df}=1, P=0.11\right)$, was a significant predictor of territory size.

In 2005, 25 Cerulean territories were delineated over two study sites using the burst sampling method. Of these, four were omitted from the analysis because they did not meet the minimum criteria of 50 observations. The mean number of locations for the 21 territories included in the analysis was 86 and ranged from 64 to 117 . Most territories were surveyed over five bouts except five territories that had four survey bouts and two territories that had three survey bouts. The territories with a lesser number of survey bouts had more than the minimum of 50 observations and had at least the minimum number of observed locations or flags as the territories that had five survey bouts (Appendix 4). Although the number of flagged bird locations $\left(\mathrm{r}^{2}=0.44, \mathrm{df}=1, P=\right.$ 0.001 ) was a significant predictor of territory size in 2005 , the numbers of observed locations $\left(\mathrm{r}^{2}=0.009, \mathrm{df}=1, P=0.67\right)$ and the number of survey bouts $\left(\mathrm{r}^{2}=0.04, \mathrm{df}=1\right.$, $P=0.40)$ were not.

\section{Territory Size}

Mean MCP territory size in 2004 was $3132 \mathrm{~m}^{2}(n=30)$ and in 2005 was $3689 \mathrm{~m}^{2}$ $\left(n=21\right.$, Table 4). The mean $95 \%$ kernel home range estimate was $3408 \mathrm{~m}^{2}$ for 2005 
(Table 4) and core area estimates (50\% kernel estimate) had a mean of $457 \mathrm{~m}^{2}$ and a large range of $43-1661 \mathrm{~m}^{2}$. Neither the $95 \% \operatorname{kernel}(t=-0.94, \mathrm{df}=10, P=0.369)$ nor $50 \%$ kernel ( $t=-1.52, \mathrm{df}=7, P=0.173)$ estimates were statistically different between study sites in 2005. Small numbers of delineated territories precluded comparing territory size between sites in 2004 although values are presented in Appendix 5.

\section{Summary Gap Data}

In 2004, mean gap density within MCP territories was $1.0 \pm 0.1$ gaps per $500 \mathrm{~m}^{2}$ (range $=0.1-2.7$, Table 5) and the average proportion of territory covered by gaps (total gap area) was $23 \% \pm 3 \%$ (range $4-60 \%$ ). The average amount of perimeter per $500 \mathrm{~m}^{2}$ was $29.1 \pm 2.4 \mathrm{~m}$ (Table 5). In 2005, the mean gap density for the $95 \%$ kernel home range estimates was $0.9 \pm 0.1$ gaps per $500 \mathrm{~m}^{2}$ (range 0.4-1.8, Table 5) and the average total gap area per territory was $16 \% \pm 2 \%$ (range $=3-38 \%$ ). The average amount of perimeter per $500 \mathrm{~m}^{2}$ was $23.1 \pm 2.2 \mathrm{~m}$ (Table 5 ).

Of the four gap variables reported above, only gap density was related to territory size (Table 6). In both 2004 and 2005, higher gap densities were found among smaller territories (Fig. 1) even though field and territory estimating methods differed between years.

In 2005, gap density in territories was greater on Hart Ridge than on Snake Ridge $(t=-2.76, \mathrm{df}=19, P=0.012)$. Therefore, the four variables were tested separately between sites. On Hart Ridge gap densities within the core areas were higher than those within the territories or the random sampling plots (Table 2). On Snake Ridge, no statistical differences were detected, although the densities within the core areas were somewhat higher (Table 2). The average total gap area and the perimeter amounts did not differ between territories, core areas, and available habitat (Table 2).

\section{Gap Type}

In 2004, gap location within the territory or on the periphery did not differ from what was expected for any of the gap types including trails, treefall gaps, or for gaps created from a diameter-limit harvest $\left(\chi^{2}=0.14, \mathrm{df}=2, P=0.93\right)$. Grapevine impeded plots were left out of the analysis in 2004 because the sample size was not enough to meet the minimum requirements of an expected cell frequency of five. There was also 
one occurrence of a road and a landslide that created large gaps that were left out of the analysis.

In 2005, gap type did not differ between territories and available habitat or between the core areas and available habitat (Table 3). However, gap type differed between gaps located within the territories and gaps located on the periphery of the territories (fishers exact, $\mathrm{df}=3, P=<0.001$, Table 7). The cell values that differed the most between observed and expected values, identified by the highest standardized residual in this test, was found for the gap type, food plot (Table 7). No food plots were included or even partially included ( $>25 \%$ of gap) within the territory although there were seven instances where a food plot was located on the edge of, or adjacent to a territory (Table 7). Gaps that had a large amount of grapevine covering saplings and small trees within the gap were found within the territory as often as on the periphery of the territory and were unimportant to the overall outcome of the test as indicated by the low standardized residual value (Table 7). Trails and treefall gaps also contributed to the significant outcome in the model although to a lesser extent. A chi-square test of independence on gap type including only trails and treefall gaps and excluding food plots and grapevine impeded gaps from the analysis, also was statistically significant $\left(\chi^{2}=\right.$ $5.39, \mathrm{df}=1, P=0.02$ ) indicating some selection is occurring between these types even when food plots are left out of the model. Gaps caused by trails were more frequently located on the periphery of the territory than expected, although trail gaps occurred within the territory as well. Treefall gaps were found more often than expected within the territory and less than expected on the periphery of the territory (Table 7).

\section{Canopy Height (2005)}

Canopy height surrounding the gap did not differ between gaps located on the periphery of the territory and within the territory on either site (Table 3). Canopy height surrounding gaps on Snake Ridge differed between territories and random sampling plots. Gaps with the highest category of canopy height surrounding the gap, $>24 \mathrm{~m}$, were found

in territories more frequently than expected and gaps with surrounding canopy heights of 18-24 $\mathrm{m}$ were found in territories less frequently than what was expected based on availability (Table 8). There were too few gaps with a surrounding canopy height of less than $18 \mathrm{~m}$ on Snake Ridge to draw conclusions from this data. 
Canopy heights surrounding gaps within the core areas also differed from gap canopy heights in the random sampling plots on Snake Ridge (Table 3). Canopy gaps with surrounding canopy heights of $>24 \mathrm{~m}$ occurred more frequently than expected within the core areas than within the random sampling plots and canopy heights of 18 to $24 \mathrm{~m}$ occurred less frequently than expected in the core areas than the random sampling plots (Table 8). There was not a large enough sample of gaps to test if the surrounding gap canopy heights in the core areas differed from the territories on this site. On Hart Ridge, the observed frequencies of gaps within the canopy height categories in core area and within territories did not differ from expected values (Table 8).

\section{Vegetation Height (2005)}

Vegetation height within the gaps did not differ between the territories and the random sampling plots on either site or between the territory peripheries and within territories on Hart Ridge. The sample size of gaps on Snake Ridge was not high enough to test gap peripheries for this site.

Within gap vegetation heights differed from expected between the core areas and the random sampling plots (fishers exact, $\mathrm{df}=4, P=0.002$ ) and also between the core areas and the territories (fishers exact, $\mathrm{df}=4, P=0.020$ ) on Hart Ridge but not on Snake Ridge (Table 3). On Hart Ridge, within gap vegetation heights in the 12 to $18 \mathrm{~m}$ category occurred more frequently than expected in the core areas compared with gap vegetation heights in the territories and in the random sampling plots (Table 9). Within gap vegetation heights of 6 to $12 \mathrm{~m}$ and greater than $18 \mathrm{~m}$ occurred less frequently than expected in the core areas (Table 9) compared to availability within in the territories or on the site.

\section{Gap Size}

Gap size did not differ in 2005 between territories and available habitat or between core areas and territories or core areas and available habitat (Table 3). Gap size did differ, however, between the periphery of territories and within territories in 2004 ( $\chi^{2}$ $=8.08, \mathrm{df}=3, P=0.045)$ and in 2005 (Table 3). In 2004, gaps in the 251-500 $\mathrm{m}^{2}$ category were found more frequently than expected within territories and less than expected on the peripheries (Table 10). Also, gaps that were greater than $501 \mathrm{~m}^{2}$ in size were included less frequently than expected within territories compared with the number 
of observations that gaps of this size were located on territory peripheries. In 2005, gaps in the greater than $501 \mathrm{~m}^{2}$ category were also found more often than expected on peripheries (Table 10). However, frequency of gaps in the $251-500 \mathrm{~m}^{2}$ category was not found to differ between territory peripheries and within territories. In 2005, the smallest category of gaps, those that were less than $100 \mathrm{~m}^{2}$ in area, were located more frequently than expected within the territories than on the edge of territories (Table 10).

\section{Distances from Territories to Large Gaps}

The type (ANCOVA: $\mathrm{F}=2.15, \mathrm{df}=3, \mathrm{P}=0.14$ ) or area (ANCOVA: $\mathrm{F}=1.86, \mathrm{df}=$ $3, \mathrm{P}=0.19$ ) of large gaps or edge were not related to distance of the territory from the gap among territories pooled across sites and years. The mean $( \pm \mathrm{SE})$ distances of Cerulean Warbler territories to the closest large gap or edge by type are displayed in appendix 6 .

\section{DISCUSSION}

\section{Gap Density}

Core areas of territories had higher gap densities than territories or than available habitat. There are several possible reasons why Cerulean Warblers may have core areas centered on a more "gappy" portion of their territory. Gaps may provide foraging opportunities for the birds as more light is let in resulting in increases in foliage surrounding the gap and increases in prey abundance (Noss 1991, Rotenberry et al. 1995, and Smith and Dallman 1996). The premise that Cerulean Warblers may spend more time near gaps to exploit prey species is hereafter referred to as the "foraging hypothesis". Besides increased insect abundance, gaps may be attractive to some birds as territory boundaries, a warm location to sing during cold mornings, and because of increased visibility and song projection (Smith and Dallman 1996). Barg (2002) suggests that Ceruleans may prefer to spend more time near canopy gaps because the openings may serve to enhance song by limiting reverberation and attenuation or to be more. This is hereafter referred to as the "song propagation hypothesis".

The result that gap density can predict territory size is biologically meaningful. This effect was found in both years when territory size was estimated by minimum convex polygons or by kernel methods and despite the differences in sampling methods between years. The correlation of smaller territories with higher gap densities is further 
evidence that forest canopy gaps are an important resource to Cerulean Warblers. Territory size has been linked to habitat quality and prey availability in other warbler species such as the Ovenbird (Seiurus aurocapillus) (Smith and Shugart 1987, Stenger 1958). Since it is known that food resources are an important factor in territory size in birds (Gill 1994), this is further evidence to support the hypothesis that foraging opportunities, possibly those associated with canopy gaps, are influencing locations of core areas within Cerulean Warbler territories.

Although my study demonstrated that canopy gaps are an important habitat component for Cerulean Warblers, more research is needed to determine what resources gaps provide. Barg (2002) suggested that the lack of foliage in canopy gaps served as ideal locations for lessened song attenuation with less reverberation off foliage and she recommended further research on canopy gaps and song projection within core areas. Although this may be an important use of gaps to Cerulean Warblers, it is likely not the only reason. The relation of territory size to gap density found in both years suggests that increased gap densities may provide higher quality habitat. Typically a bird will defend as large a territory size as possible until the additional costs of expanding the territory outweighs the benefit gained from that resource (Gill 1994). Because song in birds is primarily a means of maintaining territories and attracting mates, it is unlikely that if gaps were only used for this capacity that this alone would produce smaller territories. Territory size in passerines is often a reflection of energy requirements and food habits (Gill 1994) and has also been linked to the availability of nesting sites (Orians and Wilson 1964). Gaps may provide other resources such as increased prey abundance (Smith and Dallman 1996, Gorham 2002) or available nest sites (Oliarnyk and Robertson 1996) that would more likely be linked to territory size. Insect sampling within gaps combined with more extensive analysis of foraging behavior are needed to determine if Cerulean Warblers are using gaps for increased prey availability. If true, studies relating increased productivity and survival to higher insect abundances in gaps are needed to determine if gaps do provide higher quality habitat.

It was surprising that the total gap area within territories was not related to territory size for either year or on either site from 2005, considering the strong correlation with gap density (Table 6). For this to be true, Cerulean Warbler males must be 
responding to a resource that increases with gap number and not gap area, which could support the foraging hypothesis or available nest site. There is likely a threshold where the loss of canopy associated with gaps leads to declines in habitat quality and hence larger territories. Therefore, areas of forest with very high gap densities or very large gaps may outweigh the benefits gained from the resources that gaps provide. The largest territory sizes found on any site were territories mapped on the Lantz Farm site in 2004, which had frequent canopy breaks and one of the highest average gap areas (25\%) for territories; the result of a $40 \mathrm{~cm}$ diameter-limit harvest conducted in 1999 (Appendix 5). Although the Hart Ridge site had higher average gap areas per territory (35\%), these gaps were frequently between dominant or codominant trees with intermediate or lowercanopy trees remaining in the gap, while on the Lantz Farm site, most gaps included no mid-story or canopy-level regeneration. Jones et al. (2001) found territory sizes among Cerulean Warblers increased after one a one year time-lag following an ice storm in Ontario that reduced forest canopy as much as $60 \%$; demonstrating that Cerulean Warblers expanded their territories due to a reduction in forest canopy.

If gaps are exploited for prey, then more frequent smaller gaps or oddly-shaped gaps may be preferential to larger gaps because they will contain larger perimeter amounts where insects would be present. With this in mind, it may be surprising that gap perimeter was not related to territory size considering the gains in foraging opportunity that should result from increases in gap edge. However, high amounts of gap perimeter would also be present in territories with very large gaps or very frequent gaps where again, habitat quality may be reduced due to the loss in canopy. It is possible that the reduction in foraging opportunities resulting from the lesser amounts of canopy may be offsetting the benefits of the increased insect abundances along the gap perimeter. This may explain why gap area and perimeter are not related to territory size while gap density is highly related.

\section{Vegetative Structure of Gaps}

The findings that gaps within territory core areas on Hart Ridge contained vegetation heights more often in the $12-18 \mathrm{~m}$ category than what was expected supports the hypothesis that gaps and vegetation within them are likely exploited for prey. The song propagation hypothesis does not explain the tendency of Cerulean Warbler males on 
Hart Ridge to spend more time in areas of their territory where a tall vegetative layer is present within canopy gaps. These gaps were located within the core areas more frequently than available, perhaps due to increased foraging opportunity provided by tall vegetation within the gap that was accessible to this canopy adapted species. However, the selection of gaps with surrounding canopy height in the $>24 \mathrm{~m}$ category in core areas and within territories on Snake Ridge, supports the song propagation hypothesis of gap use. Canopy gaps with tall trees surrounding them may serve as ideal singing locations for song projection.

Previous researchers have found vegetative cover at certain strata may be important to Cerulean Warblers but have not examined vegetation heights within and surrounding canopy gaps. Weakland and Wood (2005) found greater territory densities in stands with greater amounts of foliage cover at 6-12 $\mathrm{m}$ and $>24 \mathrm{~m}$. Bosworth (2003) also found a positive association of Cerulean Warbler occurrence with canopy cover $>24$ $\mathrm{m}$ and Jones and Robertson (2001) found greater nest success among sites with greater foliage cover at 6-12 $\mathrm{m}$ and in one year, cover $>18 \mathrm{~m}$. Canopy cover at heights $>24 \mathrm{~m}$ is supported by knowledge that the species prefers a dense upper canopy and large tall trees (Lynch 1981, Jones and Robertson 2001), however, more research is needed to determine the importance of vegetative strata at mid-canopy levels. Studies examining selection of 6-12 m strata within territories and 12-18 m strata surrounding canopy gaps, especially gaps located in territory core areas, are needed to determine if this vegetative structure is important range-wide or if it is site specific.

\section{Gap Type and Size}

No selection of gap type or size occurred at the territory level compared with availability at the site. Also, selection of gap type or size did not occur at the level of the territory core area when compared with availability within the territory or at the site. However, the largest canopy gaps $\left(>500 \mathrm{~m}^{2}\right)$ were found on territory peripheries while smaller gaps $\left(<100 \mathrm{~m}^{2}\right)$ were more often included within territories, indicating some selection may occur along territory boundaries. This supports the hypothesis that Cerulean Warblers may select smaller gaps to include within territories but do not defend large portions of larger gaps. 
Food plots were located on territory peripheries more frequently than expected while treefall gaps were more often located within territories. These findings may be an artifact of gap size; food plots were some of the largest gaps present on the study sites whereas treefall gaps were generally small. Small gaps created by wind or autogenic mortality may be the most similar in structure to gaps present in old-growth forest with which this species was historically associated. The choice of territory estimator between years most likely accounts for the difference in results between years among the smaller gap classes. The MCPs were most likely a poor representation of actual territory boundaries and thus are not likely accurate enough to determine differences in location among any gaps other than the very large ones. The 2005 kernel estimates with the higher number of bird locations are a more accurate representation of actual territory boundaries and are therefore able to depict differences in gap location among smaller gaps.

Although the large gaps present at sites surveyed at Lewis Wetzel WMA were not generally included within territory boundaries, they were likely tolerated. In 2005, three Cerulean Warbler males maintained territories that bordered a food plot. Two of these individuals had few locations on the tree line on the edge of the food plot but one individual frequently foraged in black locusts located along the edge of a food plot. Cerulean Warblers were not observed flying across the large gaps created by the food plots except in one instance where the food plot narrowed into the woods and continued as a trail. The male maintaining the territory near this food plot would fly across a small section where it narrowed into the woods. Hamel (2000) suggested that Cerulean Warblers avoid large clearings due to declines in nesting success resulting from predation and parasitism, instead of responding to the presence of the edge or clearing itself. Gaps similar to food plots in size ( 0.17 and $0.32 \mathrm{ha}$ ), may be tolerated in heavily forested regions as long as predation risk and nest parasitism do not increase as a result.

Trail gaps were also found more frequently than expected on territory peripheries which may indicate that some selection on territory boundaries occurred for this gap type as well. Cerulean Warblers at Lewis Wetzel WMA were observed to use the ridgeline trails as a boundary between territories (pers. obs.). Similarly, Weakland and Wood (2005) reported that Cerulean Warblers were not avoiding internal edges (i.e. smaller 
edges such as partially open canopy roads and trails within forested locations). They found that territories were more frequently than expected $(63 \%)$ located near roads with patchy overhead canopy cover.

\section{Distance of Territories to Large Gaps}

There were no apparent effects of edge type reflected in the distance of territories to large gaps or edge including roads, powerlines, foodplots, large grapevine impeded clearings, and open canopy trails and gaslines. The scale of edge and clearings present on Lewis Wetzel WMA is much smaller than large-scale edge such as mountaintop removal mines which Ceruleans Warblers are documented to avoid (Bosworth 2003, Weakland and Wood 2005, Wood et al. 2006). These results must be taken carefully, however, considering that they were based on only 1-5 measurements of territory distances to gaps of each type except for food plots where there were 26 (Appendix 6). Repeated sampling of many gaps also occurred because the same large gap was closest to multiple territories. When this is considered, the analysis is only performed on 11 individual gaps respective to 39 territories. The scale of edge, gaps, and clearings present on Lewis Wetzel among the surveyed sites is not likely detrimental to this species within this heavily forested landscape.

\section{Management Implications}

Management for Cerulean Warblers does appear to be compatible with other wildlife management practices on Lewis Wetzel such as the maintenance of small food plots ( $<1 \mathrm{ha}$ ) or wildlife openings benefiting gap dependent species and game species. Hart Ridge, a site with three ridgetop food plots that were 0.17 to 0.32 ha in size, had one of the highest Cerulean Warbler densities. Although not enough nests were found to assess productivity on this site, the most fledglings were observed there, which was likely due to the combination of a comparatively low canopy height $(\sim 20 \mathrm{~m})$ and moderate to high reproductive success.

West Virginia forests are primarily second-growth in the stem exclusion or understory reinitiation stages and lack the old-growth forest structure (particularly large dbh trees, tall trees, canopy gaps, and vertically stratified canopy) that Cerulean Warblers have been associated with historically, and are likely adapted to exploit. Because small canopy gaps were found to be important to this species, single-tree harvests or light 
group-selection harvests that expose crowns of canopy trees to increased light and allow already established regeneration to grow into a stratified canopy would likely benefit this species. Another option is crown thinning to remove select canopy trees from the dominant and codominant crown classes creating growing space for residual trees in the same canopy strata (Hicks 1998). Harvests or thinnings that are designed to shape forests to mimic "old-growth" canopy and forest structure (large dbh tall trees, a vertically stratified canopy, and canopy gaps) may be most beneficial to this species. More research is needed on this topic to assess the harvest levels which would provide the best structure. Lower volume harvests, removing canopy levels of less than $25 \%$ in overstocked stands, would likely provide the best results increasing the number of canopy gaps without greatly reducing canopy volume. Over longer time intervals such as 20-70 years, regeneration in light harvests or thinnings will begin to grow into a stratified canopy. This will prove dually beneficial due to the increased number of gaps and the stratification provided by trees growing up within the gaps. It is likely that harvesting that results in canopy reductions and loss of large trees will result in reduced habitat quality for this species. Gaps greater than 1 ha in size were not present on the sites surveyed at Lewis Wetzel WMA and those approaching this size were not frequent. Therefore, the effects of harvests greater than 1 ha and larger on Cerulean Warblers are beyond the scope of this study to predict.

\section{LITERATURE CITED}

AcaStat Software. 2004. Research Methods Handbook. http://acastat.com

Barg, J. J. 2002. Small-scale biological phenomena in a male Neotropical migrant songbird. M.S. Thesis, Queen's University Kingston, Ontario, CA.

Barg, J. J., J. Jones, and R. J. Robertson. 2005. Describing breeding territories of migratory passerines: suggestions for sampling, choice of estimator, and delineation of core areas. Journal of Animal Ecology 74:139-149.

Beyer, H. L. 2004. Hawth's Analysis Tools for ArcGIS. http://www.spatialecology.com/htools.

Bibby, C. J., N. D. Burgess, and D. A. Hill. 1992. Bird Census Techniques. Academic Press Inc. NY, USA. 
Bosworth, S. B. 2003. Cerulean Warbler relative abundance and frequency of occurrence relative to large-scale edge. M.S. Thesis, West Virginia University, Morgantown.

Brooker, M., I. Rowley. 1995. The significance of territory size and quality in the mating strategy of the Splendid Fairy-Wren. Journal of Animal Ecology 64:614-627.

DeLaune, M. XTOOLs version 3.1 for ArcGIS. http://www.xtoolspro.com

Gill, F. B. 1994. Ornithology. W. H. Freeman and Co. New York, NY.

Gorham, L.E., S.L. King, B.D. Keeland, S. Mopper. 2002. Effects of Canopy Gaps and Flooding on Homopterans in a Bottomland Hardwood Forest. Wetlands 22:541-549.

Hamel, P. B. 2000a. Cerulean Warbler (Dendroica cerulea). The birds of North America, No. 511 (A. Poole and F. Gill, editors). The Birds of North America, Inc., Philadelphia, PA.

Hamel, P. B. 2000b. Cerulean Warbler status assessment. United States Fish and Wildlife Service, Fort Snelling, MN.

Jones, J., R. D. DeByuyn, J. J. Barg, and R. J. Robertson. 2001. Assessing the effects of natural disturbance on a neotropical migrant songbird. Ecology 82:2628-2635.

Jones, J. and R. J. Robertson. 2001. Territory and nest-site selection of Cerulean Warblers in eastern Ontario. Auk 118:727-735.

Lynch, J. M. 1981. Status of the Cerulean Warbler in the Roanoke River basin of North Carolina. Chat 45:29-35.

Martin, W. H., S. G. Boyce, A. C. Echternacht. 1993. Appalachian Oak Forests. Pages 255-303 in Biodiversity of the Southeastern United States Upland Terrestrial Communities. John Wiley \& Sons, Inc. New York.

Morse, D. H. 1976. Variables affecting the density and territory size of breeding spruce wood warblers. Ecology 57:290-301.

Newman, R. M. and T. F. Waters. 1984. Size-selective predation on Gammarus pseudolimnaeus by trout and sculpins. Ecology 65:1535-1545.

Noss, R. F. 1991. Effects of edge and internal patchiness on avian habitat use in an old growth Florida hammock. Natural Areas Journal 11:34-47.

Reynolds, H. T. 1977. The analysis of cross-classifications. Free Press, New York, New York, USA. 
Rosenberg, K. V., S. E. Barker, and R. W. Rohrberg. 2002. An Atlas of Cerulean Warbler Populations-Final Report to USFWS: 1997-2000 Breeding Seasons. Cornell Laboratory of Ornithology, Ithaca, New York.

Rotenberry, J. T., R. J. Cooper, J. M. Wunderle, and K. G. Smith. 1995. When and how are populations limited? The roles on insect outbreaks, fire, and other natural perturbations. Pages 55-84 in T. E. Martin and D. M. Finch, eds. Ecology and management of migratory birds: a synthesis and review of critical issues. Oxford University Press, Oxford, England.

Siffczyk, C., L. Brotons, K. Kangas, M. Orell. 2003. Home range size of willow tits: A response to winter habitat loss. Oecologia 136:635-642.

Smith, G. R. and J. B. Iverson. 2004. Diel activity patterns of the turtle assemblage of a northern Indiana lake. American Midland Naturalist 152:156-164.

Smith, R., and M. Dallman. 1996. Forest gap use by breeding Black-throated Green Warblers. Wilson Bulletin 108:588-591.

Smith, T. M., and H. H. Shugart. 1987. Territory size variation in the Ovenbird: The role of habitat structure. Ecology 68:695-704.

Stenger, J. 1958. Food habits and available food of Ovenbirds in relation to territory size. Auk 75:125-140.

Weakland, C. A., P. B. Wood, W. M. Ford. 2002. Responses of songbirds to diameter limit cutting in the central Appalachians of West Virginia, USA. Forest Ecology and Management 155:115-129.

Weakland, C. A. and P. B. Wood. 2005. Cerulean Warbler (Dendroica cerulea) microhabitat and landscape-level habitat characteristics in southern West Virginia. Auk 122:497-508.

Wood, P. B., S. B., Bosworth, and R. Dettmers. 2006. Cerulean Warbler abundance and occurrence relative to large-scale edge and habitat characteristics. Condor 108:154-165.

Worton, B. J. 1987. A review of the models of home range for animal movement. Ecological Modeling 38: 277-298. 
TABLE 1. Types of canopy disturbance present on each study site surveyed for Cerulean Warblers on Lewis Wetzel Wildlife Management Area and the Lantz Farm and Nature Preserve in Wetzel County, WV in 2004 and 2005.

\begin{tabular}{|c|c|c|c|c|c|c|c|c|}
\hline $\begin{array}{l}\text { Site Name } \\
\text { (abbreviation) }\end{array}$ & $\begin{array}{l}\text { Treefall } \\
\text { Gaps }\end{array}$ & $\begin{array}{l}\text { Ridgetop } \\
\text { Trail }^{b}\end{array}$ & Gasline $^{b}$ & Powerline & $\begin{array}{l}\text { Gas well } \\
\text { Clearing }\end{array}$ & $\begin{array}{l}\text { Wildlife } \\
\text { food plot }\end{array}$ & $\begin{array}{l}\text { Grapevine } \\
\text { Impeded } \\
\text { Clearing }\end{array}$ & $\begin{array}{l}\text { Diameter- } \\
\text { limit } \\
\text { Harvest }\end{array}$ \\
\hline $\begin{array}{l}\text { Lantz Farm Ridge } \\
\text { (LF) }\end{array}$ & $X$ & $X$ & $X$ & & & & & $X$ \\
\hline $\begin{array}{l}\text { Owlshead } \\
(\mathrm{OH})\end{array}$ & $X$ & $X$ & $X$ & $X$ & & & & \\
\hline $\begin{array}{l}\text { Hart Ridge }{ }^{a} \\
(\mathrm{HR})\end{array}$ & $X$ & $X$ & & & & $\mathrm{X}$ & $X$ & \\
\hline $\begin{array}{l}\text { Lesin Ridge } \\
\text { (LR) }\end{array}$ & $X$ & $X$ & & & & & $X$ & \\
\hline $\begin{array}{l}\text { Laurel Patch } \\
\text { (LP) }\end{array}$ & $X$ & $X$ & $X$ & $X$ & $X$ & $X$ & & \\
\hline $\begin{array}{l}\text { Snake Ridge }{ }^{\text {a }} \\
\text { (SR) }\end{array}$ & $X$ & & & & & & $X$ & \\
\hline $\begin{array}{l}\text { Outer Ridge } \\
\text { (OR) }\end{array}$ & $X$ & & & & & & & \\
\hline
\end{tabular}

\section{${ }^{a}$ Site surveyed in 2005.}

${ }^{\mathrm{b}}$ Disturbance types were similar in structure and combined under the classification trail gaps in all analyses. 
TABLE 2. Two-tailed $t$-test results of summary gap variables on Hart Ridge (HR) and Snake Ridge (SR) sites on Lewis Wetzel Wildlife Management Area in Wetzel County, WV in 2005.

\begin{tabular}{|c|c|c|c|c|c|c|c|}
\hline & & Territory & Available & Core & & & \\
\hline Variable & Site & $\bar{x} \pm \mathrm{SE}$ & $\bar{x} \pm \mathrm{SE}$ & $\bar{x} \pm \mathrm{SE}$ & $t$ & $\mathrm{df}$ & $P$ \\
\hline \multicolumn{8}{|c|}{ Gap density ${ }^{a}$} \\
\hline & HR & $1.0 \pm 0.1$ & - & $2.9 \pm 0.5$ & 3.48 & 15 & 0.003 \\
\hline & HR & - & $0.9 \pm 0.1$ & $2.9 \pm 0.5$ & 3.86 & 14 & 0.002 \\
\hline & HR & $1.0 \pm 0.1$ & $0.9 \pm 0.1$ & - & -0.97 & 20 & 0.342 \\
\hline & SR & $0.7 \pm 0.1$ & - & $1.1 \pm 0.3$ & 1.20 & 7 & 0.193 \\
\hline & SR & - & $0.8 \pm 0.1$ & $1.1 \pm 0.3$ & 1.09 & 7 & 0.310 \\
\hline & SR & $0.7 \pm 0.1$ & $0.8 \pm 0.1$ & - & -0.33 & 12 & 0.323 \\
\hline \multicolumn{8}{|c|}{ Average gap size } \\
\hline & HR & $382.3 \pm 64.6$ & $341.9 \pm 57.5$ & - & 0.46 & 27.0 & 0.652 \\
\hline & HR & - & $341.9 \pm 57.5$ & $545.1 \pm 243.0$ & 0.81 & 13.3 & 0.432 \\
\hline & HR & $382.3 \pm 64.6$ & - & $545.1 \pm 243.0$ & 0.65 & 13.7 & 0.527 \\
\hline & SR & $243.7 \pm 42.3$ & $195.6 \pm 41.4$ & - & 0.93 & 13.7 & 0.371 \\
\hline & SR & - & $195.6 \pm 41.4$ & $209.4 \pm 38.7$ & 0.24 & 11.1 & 0.811 \\
\hline & SR & $243.7 \pm 42.3$ & - & $209.4 \pm 38.7$ & -0.60 & 9.88 & 0.563 \\
\hline \multicolumn{8}{|c|}{ Total gap area (\%) } \\
\hline & $\mathrm{HR}$ & $17 \pm 3$ & - & $17 \pm 5$ & 0.09 & 20 & 0.931 \\
\hline & HR & - & $22 \pm 3$ & $17 \pm 5$ & -0.83 & 21 & 0.417 \\
\hline & HR & $17 \pm 3$ & $22 \pm 3$ & - & 1.33 & 28 & 0.196 \\
\hline & SR & $13 \pm 1$ & - & $12 \pm 4$ & -0.41 & 7 & 0.694 \\
\hline & SR & - & $17 \pm 2$ & $12 \pm 4$ & -1.15 & 9 & 0.281 \\
\hline & SR & $13 \pm 1$ & $17 \pm 2$ & - & -1.39 & 12 & 0.189 \\
\hline \multicolumn{8}{|c|}{ Gap perimeter $(\mathrm{m})^{\mathrm{a}}$} \\
\hline & HR & $25.6 \pm 3.0$ & $34.1 \pm 2.7$ & - & -1.77 & 22.3 & 0.090 \\
\hline & SR & $17.9 \pm 1.9$ & $25.7 \pm 3.3$ & - & -2.05 & 13.8 & 0.060 \\
\hline
\end{tabular}

${ }^{a}$ Value is calculated per $500 \mathrm{~m}^{2}$. 
TABLE 3. Results of chi-square analysis of canopy gap characteristics of Cerulean Warbler territories, core areas, and random sampling plots on Snake Ridge (SR) and Hart Ridge (HR) at the Lewis Wetzel Wildlife Management Area in Wetzel County, WV in 2005.

\begin{tabular}{|c|c|c|c|c|c|c|c|c|}
\hline \multirow[b]{2}{*}{ Test } & \multirow[b]{2}{*}{ Site } & \multicolumn{3}{|c|}{ Chi-square } & \multicolumn{3}{|c|}{ Fisher's exact } & \multirow[b]{2}{*}{$n$} \\
\hline & & $\chi^{2}$ & $\mathrm{df}$ & $P$ & Table & $P$ & $\%$ cells $<5$ & \\
\hline \multicolumn{9}{|l|}{ Territory vs. Available } \\
\hline Canopy height & SR & 9.33 & 2 & 0.009 & 0.0006 & 0.008 & 33 & 66 \\
\hline Canopy height & HR & 2.21 & 2 & 0.331 & - & - & - & 135 \\
\hline Vegetation height & SR & 2.86 & 4 & 0.582 & 0.0029 & 0.657 & 40 & 66 \\
\hline Vegetation height & HR & 2.86 & 4 & 0.582 & - & - & - & 136 \\
\hline Gap type & SR & 0.30 & 1 & 0.581 & - & - & - & 66 \\
\hline Gap type & HR & 2.51 & 3 & 0.474 & - & - & - & 137 \\
\hline Gap type & All & 1.87 & 3 & 0.601 & - & - & - & 203 \\
\hline Gap size & All & 0.86 & 3 & 0.835 & - & - & - & 184 \\
\hline \multicolumn{9}{|c|}{ Periphery vs. In Territory ${ }^{a}$} \\
\hline Canopy height & HR & 0.82 & 2 & 0.665 & - & - & - & 80 \\
\hline Vegetation height & HR & 5.77 & 4 & 0.217 & 0.0004 & 0.173 & 40 & 80 \\
\hline Gap type & All & 18.58 & 3 & $<0.001$ & $1.79 \mathrm{E}-06$ & $<0.001$ & 25 & 115 \\
\hline Gap size & All & 11.96 & 3 & 0.008 & 4.77E-05 & 0.008 & 25 & 104 \\
\hline \multicolumn{9}{|c|}{ Core Area vs. Territory ${ }^{b}$} \\
\hline Canopy height & HR & 0.48 & 2 & 0.788 & 0.0520 & 0.765 & 33 & 93 \\
\hline Vegetation height & SR & 2.78 & 3 & 0.427 & 0.0151 & 0.518 & 50 & 45 \\
\hline Vegetation height & HR & 11.75 & 4 & 0.019 & 0.0001 & 0.020 & 50 & 95 \\
\hline Gap size & All & 0.39 & 3 & 0.943 & 0.0120 & 0.909 & 25 & 104 \\
\hline \multicolumn{9}{|l|}{ Core Area vs. Available } \\
\hline Canopy height & $\mathrm{SR}$ & 7.84 & 2 & 0.020 & 0.0018 & 0.013 & 33 & 49 \\
\hline Canopy height & HR & 1.35 & 2 & 0.510 & 0.0309 & 0.529 & 33 & 88 \\
\hline Vegetation height & HR & 17.01 & 4 & 0.002 & $3.42 \mathrm{E}-06$ & 0.002 & 30 & 89 \\
\hline Gap type & All & 4.90 & 3 & 0.179 & - & - & - & 138 \\
\hline Gap size & All & 0.11 & 3 & 0.990 & 0.0121 & 0.987 & 25 & 125 \\
\hline
\end{tabular}

${ }^{a}$ Analysis between gaps located on a territory boundary and gaps contained within a territory.

${ }^{\mathrm{b}}$ Analysis between gaps located within a core area $(50 \%$ kernel estimate) and all other gaps at least partially contained within a territory. 
TABLE 4. Mean ( \pm SE and range) territory sizes of Cerulean Warblers in Wetzel County, WV estimated by minimum convex polygon, $95 \%$ fixed kernel methods, and $50 \%$ fixed kernel core area estimates.

\begin{tabular}{lccc}
\hline \hline & $n$ & $\bar{x} \pm \mathrm{SE}$ & Range \\
\hline $\begin{array}{l}\text { 2004 Territory } \\
\text { MCP }\left(\mathrm{m}^{2}\right)\end{array}$ & 30 & $3132 \pm 571$ & $635-14625$ \\
& & & \\
2005 Territory & 21 & $3689 \pm 665$ & $546-13203$ \\
MCP $\left(\mathrm{m}^{2}\right)^{\mathrm{a}}$ & 21 & $3408 \pm 558$ & $603-9616$ \\
95\% Kernel $\left(\mathrm{m}^{2}\right)^{\mathrm{a}}$ & 14 & $3016 \pm 645$ & $603-8909$ \\
Hart Ridge & 7 & $4193 \pm 1073$ & $645-9616$ \\
Snake Ridge & & & \\
2005 Core Area & 21 & $457 \pm 88$ & $43-1661$ \\
50\% Kernel $\left(\mathrm{m}^{2}\right)^{\text {a }}$ & 14 & $345 \pm 69$ & $43-1009$ \\
Hart Ridge & 7 & $680 \pm 209$ & $45-1661$ \\
Snake Ridge & &
\end{tabular}

${ }^{a}$ Estimate is for both sites from 2005 combined. 
TABLE 5. Means ( \pm SE and range) of summary canopy gap variables within Cerulean Warbler territories, core areas, and random sampling plots in Wetzel County, WV.

\begin{tabular}{|c|c|c|c|}
\hline & $n^{\mathrm{c}}$ & $\overline{\bar{x}} \pm \mathrm{SE}$ & Range \\
\hline \multicolumn{4}{|l|}{2004 Territory } \\
\hline Number of gaps ${ }^{a}$ & 29 & $4.4 \pm 0.5$ & $1-12$ \\
\hline Gap density a,b & 29 & $1.0 \pm 0.1$ & $0.1-2.7$ \\
\hline Avg. gap size $\left(m^{2}\right)^{a}$ & 28 & $136.95 \pm 16.7$ & $10.5-344.7$ \\
\hline Total gap area (\%) & 28 & $23 \pm 3$ & $4-60$ \\
\hline Gap perimeter $(m)^{b}$ & 28 & $29.1 \pm 2.4$ & $7.7-55.8$ \\
\hline \multicolumn{4}{|l|}{2005 Territory } \\
\hline Number of gaps a & 21 & $4.9 \pm 0.6$ & $1-10$ \\
\hline Gap density a,b & 21 & $0.9 \pm 0.1$ & $0.4-1.8$ \\
\hline Avg. gap size $\left(m^{2}\right)^{a}$ & 21 & $94.1 \pm 10.9$ & 19.4-214.9 \\
\hline Total gap area (\%) & 21 & $16 \pm 2$ & $3-38$ \\
\hline Gap perimeter $(\mathrm{m})^{\mathrm{b}}$ & 21 & $23.1 \pm 2.2$ & $6.2-47.9$ \\
\hline \multicolumn{4}{|l|}{2005 Available } \\
\hline Number of gaps a & 25 & $4.0 \pm 0.3$ & $2-7$ \\
\hline Gap density a,b & 25 & $0.9 \pm 0.1$ & $0.4-1.6$ \\
\hline Avg. gap size $\left(m^{2}\right)^{a}$ & 25 & $126.4 \pm 16.4$ & $28.3-340.0$ \\
\hline Total gap area (\%) & 25 & $20 \pm 2$ & $4-46$ \\
\hline Gap perimeter $(\mathrm{m})^{\mathrm{b}}$ & 25 & $31.1 \pm 2.2$ & $11.7-59.0$ \\
\hline \multicolumn{4}{|l|}{2005 Core Area } \\
\hline Number of gaps ${ }^{a}$ & 21 & $1.8 \pm 0.3$ & $0-5$ \\
\hline Gap density a, b & 21 & $2.3 \pm 0.4$ & $0.0-6.7$ \\
\hline Avg. gap size $\left(\mathrm{m}^{2}\right)^{\mathrm{a}, \mathrm{d}}$ & 18 & $451.9 \pm 178.3$ & $34.4-3163.3$ \\
\hline Total gap area (\%) & 21 & $15 \pm 4$ & $0-52$ \\
\hline
\end{tabular}

${ }^{a}$ Calculation includes all gaps at least partially located within the territory, core area, or random sampling plot boundary regardless of the gap size or percent contained within the boundary.

${ }^{\mathrm{b}}$ Value is calculated per $500 \mathrm{~m}^{2}$.

${ }^{c}$ Value is the number of territories or random sampling plots.

d Average gap size is comparatively high (although not statistically different) for core areas due to few gaps occurring within them because of their small size. Two instances of a large food plot located on the edge of a core area resulted in a high average size estimate for this parameter. 
TABLE 6. Results of linear regression of Cerulean Warbler territory size related to summary gap variables.

\begin{tabular}{lccccc}
\hline \hline Variable & Year & $F$ & df & $P$ & $r^{2}$ \\
\hline Gap density $^{\text {a }}$ & 2004 & 39.64 & 1 & $<\mathbf{0 . 0 0 1}$ & 0.59 \\
Gap density $^{\mathrm{a}}$ & 2005 & 16.36 & 1 & $<\mathbf{0 . 0 0 1}$ & 0.46 \\
Total gap area $^{\mathrm{b}}$ & 2004 & 0.10 & 1 & 0.751 & 0.00 \\
Total gap area $^{\mathrm{b}}$ & 2005 & 0.00 & 1 & 0.968 & 0.00 \\
Gap perimeter $^{\mathrm{c}}$ & 2004 & 0.08 & 1 & 0.778 & 0.00 \\
Gap perimeter $^{\mathrm{c}}$ & 2005 & 0.00 & 1 & 0.953 & 0.00 \\
\hline
\end{tabular}

${ }^{a}$ Density was calculated as the number of gaps per $500 \mathrm{~m}^{2}$.

${ }^{\mathrm{b}}$ Calculated as a proportion: total gap area within territory/territory size.

${ }^{\mathrm{c}}$ Calculated as the amount of perimeter $(\mathrm{m})$ per $500 \mathrm{~m}^{2}$. 
TABLE 7. Observed and expected values from chi-square analysis of canopy gap type between gaps located on Cerulean Warbler territory peripheries and those located within territories in Wetzel County, WV in 2005. The standardized residual values farthest from zero indicate the greatest differences between observed and expected values of individual cells.

\begin{tabular}{ccc}
\hline \hline & Periphery & In territory \\
\hline Trail & & \\
Observed & 10 & 9 \\
Expected & 6.77 & 12.23 \\
Std. Resid. & 1.24 & -0.92 \\
Treefall & & \\
Observed & 18 & 54 \\
Expected & 25.67 & 46.33 \\
Std. Resid. & -1.51 & 1.13 \\
Grapevine & & \\
Observed & 6 & 11 \\
Expected & 6.06 & 10.93 \\
Std. Resid. & -0.02 & 0.02 \\
Food plot & & \\
Observed & 7 & 0 \\
Expected & 2.50 & 4.50 \\
Std. Resid. & 2.85 & -2.12 \\
\hline
\end{tabular}


TABLE 8. Observed and expected values of frequency data from chi-square analysis of surrounding gap canopy heights on Snake Ridge in Wetzel County, WV in 2005. The standardized residual values farthest from zero indicate the greatest differences between observed and expected values of individual cells.

\begin{tabular}{ccccc}
\hline & Territory & Available & Core Area & Available \\
\hline$>12-18 \mathrm{~m}$ & & & & \\
Observed & 3 & 6 & 2 & 6 \\
Expected & 4.23 & 4.77 & 2.29 & 5.71 \\
Std. Resid. & -0.60 & 0.56 & -0.19 & 0.12 \\
$>18-24 \mathrm{~m}$ & & & & \\
Observed & 5 & 16 & 1 & 16 \\
Expected & 9.86 & 11.14 & 4.86 & 12.14 \\
Std. Resid. & -1.55 & 1.46 & -1.75 & 1.11 \\
$>24$ m & & & & \\
Observed & 23 & 13 & 11 & 13 \\
Expected & 16.91 & 19.01 & 6.86 & 17.14 \\
Std. Resid. & 1.48 & -1.38 & 1.58 & -1.00 \\
\hline
\end{tabular}


TABLE 9. Observed and expected values of frequency data from chi-square analysis of within gap vegetation heights on Hart Ridge in Wetzel County, WV in 2005. The standardized residual values farthest from zero indicate the greatest differences between observed and expected values of individual cells.

\begin{tabular}{ccccc}
\hline \hline & Core & Territory & Core & Available \\
\hline 0-3 m & & & & \\
Observed & 7 & 27 & 7 & 24 \\
Expected & 8.59 & 25.41 & 8.36 & 22.64 \\
Std. Resid. & -0.54 & 0.32 & -0.47 & 0.29 \\
$>3-6$ m & & & & \\
Observed & 1 & 5 & 1 & 6 \\
Expected & 1.52 & 4.48 & 1.89 & 5.11 \\
Std. Resid. & -0.42 & 0.24 & -0.65 & 0.39 \\
$>6$-12 m & & & & \\
Observed & 1 & 17 & 1 & 15 \\
Expected & 4.55 & 13.45 & 4.31 & 11.69 \\
Std. Resid. & -1.66 & 0.97 & -1.60 & 0.97 \\
$>12-18$ m & & & & \\
Observed & 15 & 19 & 15 & 13 \\
Expected & 8.59 & 25.41 & 7.55 & 20.45 \\
Std. Resid. & 2.19 & -1.27 & 2.71 & -1.65 \\
$>18$ m & & & & \\
Observed & 0 & 3 & 0 & 7 \\
Expected & 0.76 & 2.24 & 1.89 & 5.11 \\
Std. Resid. & -0.87 & 0.51 & -1.37 & 0.83 \\
\hline
\end{tabular}


TABLE 10. Observed and expected values from chi-square analysis of canopy gap size between gaps located on Cerulean Warbler territory peripheries and those located within territories across all sites by year in Wetzel County, WV. The standardized residual values farthest from zero indicate the greatest differences between observed and expected values of individual cells.

\begin{tabular}{|c|c|c|c|c|}
\hline & \multicolumn{2}{|c|}{2004} & \multicolumn{2}{|c|}{2005} \\
\hline & Periphery & In territory & Periphery & In territory \\
\hline \multicolumn{5}{|l|}{$0-100 \mathrm{~m}^{2}$} \\
\hline Observed & 20 & 38 & 12 & 39 \\
\hline Expected & 20.13 & 37.87 & 18.14 & 32.86 \\
\hline Std. resid. & -0.03 & 0.02 & -1.44 & 1.07 \\
\hline \multicolumn{5}{|l|}{$101-250 \mathrm{~m}^{2}$} \\
\hline Observed & 9 & 16 & 15 & 18 \\
\hline Expected & 8.68 & 16.32 & 11.74 & 21.26 \\
\hline Std. resid. & 0.11 & -0.08 & 0.95 & -0.71 \\
\hline \multicolumn{5}{|l|}{$251-500 \mathrm{~m}^{2}$} \\
\hline Observed & 2 & 16 & 3 & 8 \\
\hline Expected & 6.25 & 11.75 & 3.91 & 7.09 \\
\hline Std. resid. & -1.70 & 1.24 & -0.46 & 0.34 \\
\hline \multicolumn{5}{|l|}{$>500 \mathrm{~m}^{2}$} \\
\hline Observed & 11 & 9 & 7 & 2 \\
\hline Expected & 6.94 & 13.06 & 3.20 & 5.80 \\
\hline Std. resid. & 1.54 & -1.12 & 2.12 & -1.58 \\
\hline
\end{tabular}




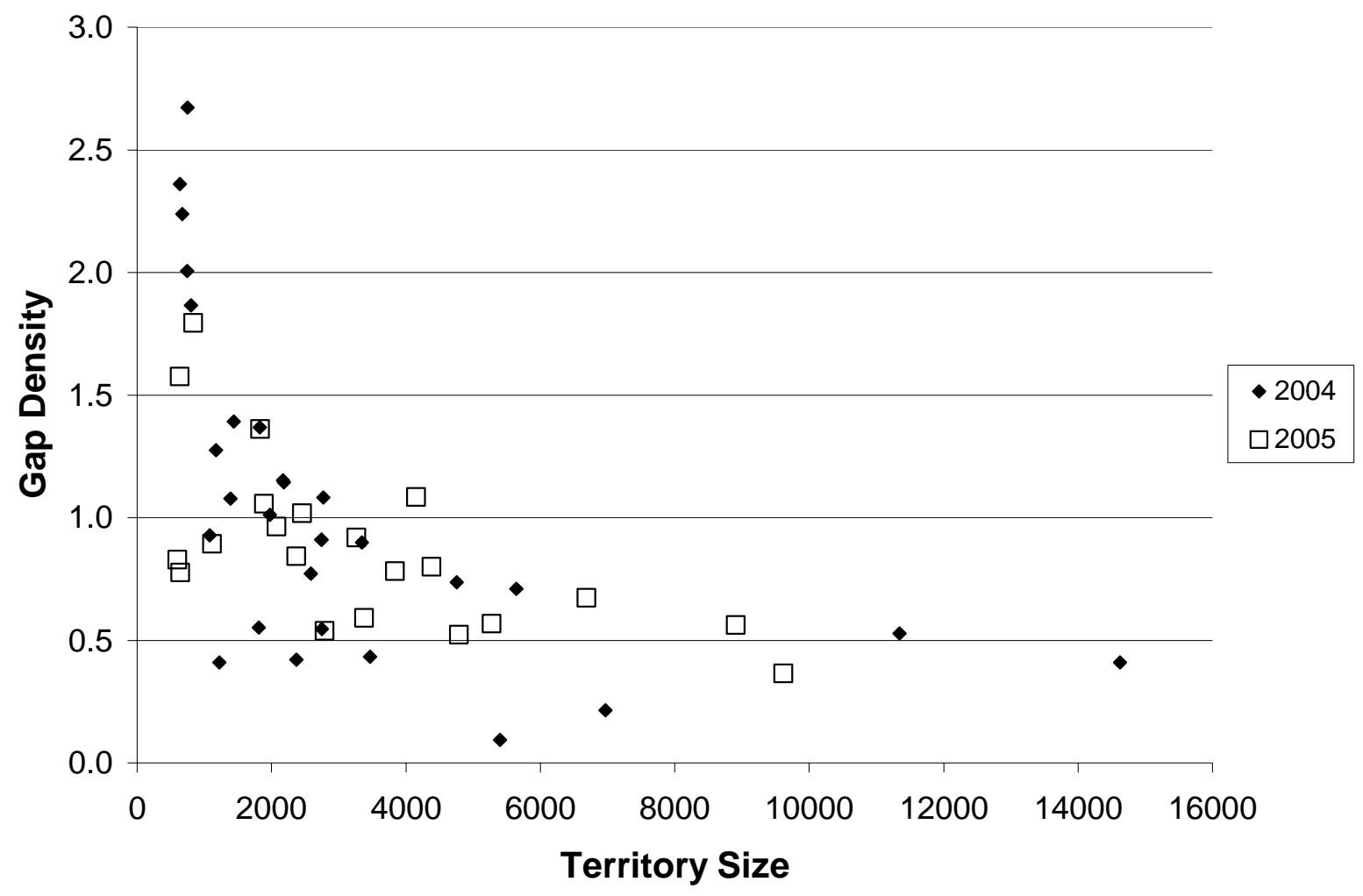

FIG. 1. Plot of territory size $\left(\mathrm{m}^{2}\right)$ and canopy gap density (per $500 \mathrm{~m}^{2}$ ) among Cerulean Warbler territories in Wetzel County, WV. Territory sizes were estimated by minimum convex polygons in 2004 and by $95 \%$ fixed kernels in 2005. Linear regression results were significant in $2004\left(\mathrm{r}^{2}=0.59, \mathrm{~F}=39.64, \mathrm{df}=1, \mathrm{P}=<0.001\right)$ and $2005\left(\mathrm{r}^{2}=0.46, \mathrm{~F}\right.$ $=16.36, \mathrm{df}=1, \mathrm{P}=<0.001)$. 
Appendix 1. Canopy gap variables measured in Cerulean Warbler territories and random sampling plots in Wetzel County, WV in 2004 and 2005.

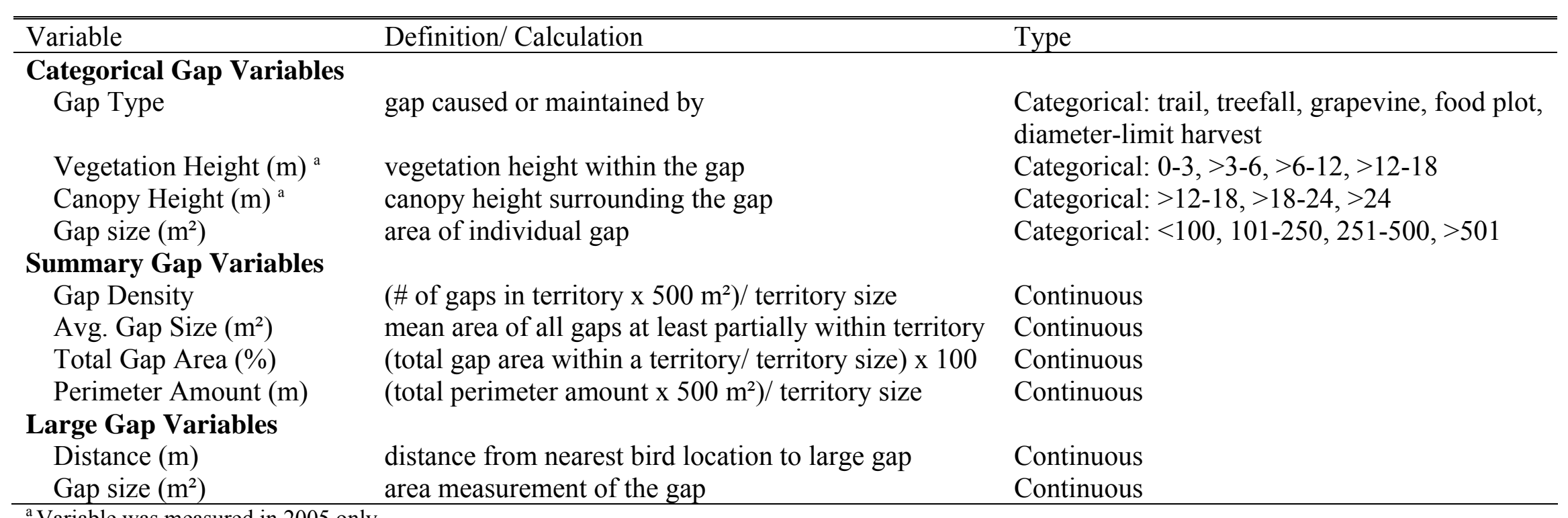


Appendix 2. Example of a Cerulean Warbler territory represented by a 95\% fixed kernel estimate. Dots represent bird locations. Interior open shapes represent the $50 \%$ fixed kernel core area estimate while filled shapes represent canopy gap shapefiles clipped with the $95 \%$ kernel shapefile. The dotted line represents a $5 \mathrm{~m}$ buffer around the territory.

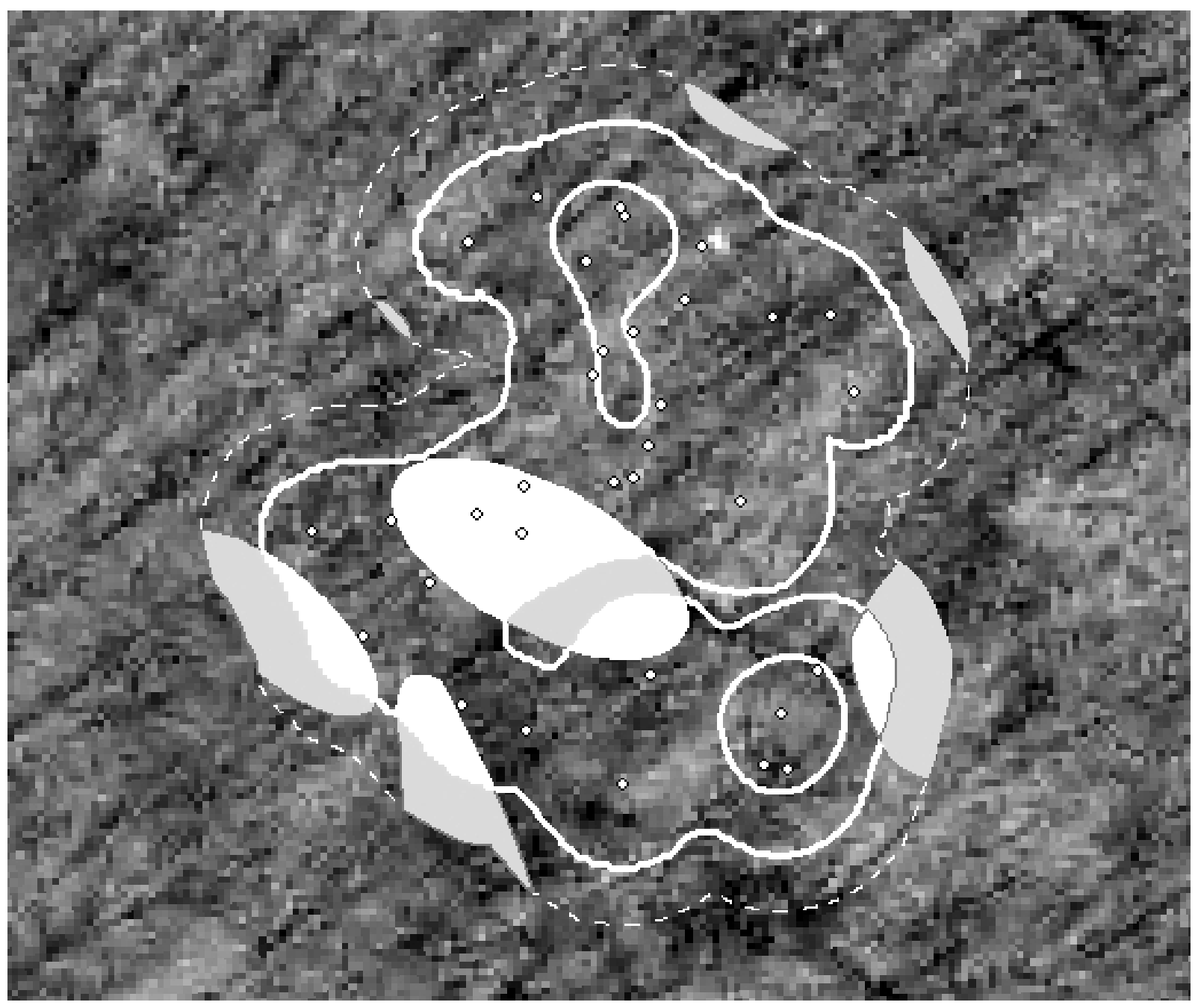


Appendix 3. Minimum convex polygon (MCP) territory size estimates of Cerulean Warblers on Lewis Wetzel Wildlife Management Area and Lantz Farm and Nature Preserve in Wetzel County, WV in 2004.

\begin{tabular}{|c|c|c|c|c|}
\hline Site & Territory name & $\mathrm{MCP}\left(\mathrm{m}^{2}\right)$ & \# of flags & \# of obs \\
\hline Hart Ridge & HR06 & 2743 & 8 & 8 \\
\hline Hart Ridge & HR08 & 749 & 7 & 7 \\
\hline Hart Ridge & HR09 & 1078 & 12 & 12 \\
\hline Hart Ridge & HR10 & 2589 & 7 & 7 \\
\hline Hart Ridge & HR11 & 3342 & 12 & 12 \\
\hline Hart Ridge & HR12 & 1438 & 7 & 7 \\
\hline Hart Ridge & HR17 & 635 & 6 & 6 \\
\hline Hart Ridge & HR18 & 2771 & 9 & 9 \\
\hline Owlshead & $\mathrm{OH} 07$ & 4752 & 14 & 14 \\
\hline Owlshead & $\mathrm{OH} 11$ & 6970 & 10 & 10 \\
\hline Owlshead & $\mathrm{OH} 12$ & 1975 & 12 & 12 \\
\hline Owlshead & $\mathrm{OH} 13$ & 3468 & 5 & 6 \\
\hline Laurel Patch Trail & LP08 & 2749 & 7 & 8 \\
\hline Lantz Ridge & LF01 & 2746 & 6 & 7 \\
\hline Lantz Ridge & LF03 & 14625 & 9 & 9 \\
\hline Lantz Ridge & LF05 & 11342 & 11 & 11 \\
\hline Outer Ridge & OR01 & 2585 & 10 & 10 \\
\hline Outer Ridge & OR02 & 1813 & 10 & 10 \\
\hline Outer Ridge & OR03 & 1223 & 7 & 7 \\
\hline Outer Ridge & OR05 & 1391 & 10 & 13 \\
\hline Outer Ridge & OR06 & 2168 & 9 & 9 \\
\hline Lesin Ridge & LR04 & 1176 & 7 & 9 \\
\hline Lesin Ridge & LR05 & 748 & 8 & 8 \\
\hline Lesin Ridge & LR07 & 1826 & 8 & 8 \\
\hline Lesin Ridge & LR09 & 5399 & 10 & 10 \\
\hline Lesin Ridge & LR13 & 2185 & 8 & 8 \\
\hline Lesin Ridge & LR16 & 804 & 6 & 7 \\
\hline Lesin Ridge & LR17 & 670 & 7 & 7 \\
\hline Snake Ridge & SR05 & 2370 & 7 & 7 \\
\hline Snake Ridge & SR13 & 5641 & 18 & 18 \\
\hline
\end{tabular}


Appendix 4. Territory sizes for Cerulean Warblers on Lewis Wetzel Wildlife Management Area in Wetzel County, WV in 2005. Territory sizes are estimated using minimum convex polygon (MCP) and fixed kernel methods.

\begin{tabular}{|c|c|c|c|c|c|c|c|c|}
\hline Site & $\begin{array}{c}\text { Territory } \\
\text { name }\end{array}$ & $\begin{array}{c}\text { 95\% kernel } \\
\left(\mathrm{m}^{2}\right)\end{array}$ & $\begin{array}{c}50 \% \text { kernel } \\
\left(\mathrm{m}^{2}\right)\end{array}$ & $h^{\mathrm{a}}$ & $\operatorname{MCP}\left(\mathrm{m}^{2}\right)$ & $\begin{array}{l}\text { \# of } \\
\text { flags }\end{array}$ & $\begin{array}{l}\# \text { of } \\
\text { obs }\end{array}$ & $\begin{array}{l}\text { \# of } \\
\text { bouts }\end{array}$ \\
\hline Hart Ridge & HR01 & 2791 & 630 & 4 & 2981 & 43 & 84 & 5 \\
\hline Hart Ridge & HR02 & 6686 & 371 & 9 & 5962 & 48 & 86 & 5 \\
\hline Hart Ridge & HR03 & 836 & 75 & 3 & 890 & 33 & 117 & 5 \\
\hline Hart Ridge & HR04 & 4381 & 662 & 7 & 3757 & 40 & 93 & 5 \\
\hline Hart Ridge & HR08 & 2458 & 301 & 5 & 1988 & 44 & 92 & 5 \\
\hline Hart Ridge & HR10 & 1893 & 303 & 4 & 1418 & 31 & 77 & 4 \\
\hline Hart Ridge & HR11 & 4152 & 234 & 8 & 5687 & 42 & 98 & 5 \\
\hline Hart Ridge & HR12 & 2077 & 208 & 5 & 2838 & 32 & 88 & 5 \\
\hline Hart Ridge & HR13 & 1836 & 196 & 5 & 2970 & 38 & 88 & 5 \\
\hline Hart Ridge & HR16 & 1120 & 229 & 3 & 1118 & 33 & 86 & 5 \\
\hline Hart Ridge & HR17 & 603 & 300 & 4 & 1257 & 35 & 88 & 5 \\
\hline Hart Ridge & HR20 & 635 & 43 & 3 & 1319 & 26 & 97 & 4 \\
\hline Hart Ridge & HR21 & 8909 & 1009 & 13 & 13203 & 50 & 92 & 5 \\
\hline Hart Ridge & HR18 & 3840 & 277 & 7 & 6440 & 40 & 59 & 4 \\
\hline Snake Ridge & SR14 & 3268 & 331 & 7 & 3905 & 33 & 98 & 5 \\
\hline Snake Ridge & SR08 & 3383 & 601 & 6 & 2540 & 31 & 65 & 4 \\
\hline Snake Ridge & SR05 & 9616 & 1661 & 11 & 8961 & 44 & 105 & 5 \\
\hline Snake Ridge & SR16 & 2372 & 234 & 5 & 1804 & 33 & 64 & 4 \\
\hline Snake Ridge & SR17 & 4793 & 892 & 7 & 4301 & 40 & 99 & 5 \\
\hline Snake Ridge & SR15 & 5280 & 997 & 8 & 3592 & 27 & 65 & 3 \\
\hline Snake Ridge & SR09 & 645 & 45 & 3 & 546 & 20 & 75 & 3 \\
\hline
\end{tabular}

${ }^{a}$ The smoothing parameter for the fixed kernel estimate, selected by least-squares cross-validation. 
Appendix 5. Summary gap variables $(\bar{x} \pm \mathrm{SE})$ for 2004 Cerulean Warbler territories by site on Lewis Wetzel Wildlife Management Area in Wetzel County, WV.

\begin{tabular}{lccccc}
\hline Site & $\begin{array}{c}\text { Number of } \\
\text { territories }\end{array}$ & $\begin{array}{c}\bar{x} \text { Territory size } \\
\left(\mathrm{m}^{2}\right)\end{array}$ & $\begin{array}{c}\bar{x} \text { gap } \\
\text { density }\end{array}$ & $\begin{array}{c}\bar{x} \text { perimeter } \\
(\mathrm{m}){ }^{\text {a }}\end{array}$ & $\begin{array}{c}\text { Total gap } \\
\text { area }(\%)\end{array}$ \\
\hline Lantz Farm Ridge & 3 & $9571 \pm 3542$ & $0.62 \pm 0.15$ & $43.53 \pm 6.80$ & $25 \pm 2$ \\
Owlshead & 4 & $4291 \pm 1058$ & $0.60 \pm 0.17$ & $17.33 \pm 3.22$ & $14 \pm 4$ \\
Hart Ridge & 8 & $1918 \pm 374$ & $1.38 \pm 0.26$ & $35.03 \pm 4.65$ & $35 \pm 5$ \\
Lesin Ridge & 6 & $1235 \pm 258$ & $1.65 \pm 0.18$ & $25.64 \pm 5.29$ & $17 \pm 7$ \\
Laurel Patch & 1 & $2749 \pm 0$ & $0.55 \pm 0.00$ & $19.22 \pm 0.00$ & $12 \pm 0$ \\
Snake Ridge & 2 & $4006 \pm 1636$ & $0.57 \pm 0.14$ & $26.74 \pm 6.57$ & $2 \pm 0$ \\
Outer Ridge & 5 & $1649 \pm 213$ & $0.80 \pm 0.19$ & $26.83 \pm 1.97$ & $17 \pm 3$ \\
\hline
\end{tabular}

${ }^{\text {a }}$ Value is calculated per $500 \mathrm{~m}^{2}$.

Appendix 6. Mean $( \pm \mathrm{SE})$ distances of Cerulean Warbler territories from the nearest large gap or edge across all sites in 2004 and 2005 in Wetzel County, WV. Multiple territories may occur nearest to the same gap.

\begin{tabular}{lccc}
\hline \hline & Distance $(\mathrm{m})$ & $\begin{array}{c}\text { Number of } \\
\text { Territories }\end{array}$ & $\begin{array}{c}\text { Number } \\
\text { of Gaps }\end{array}$ \\
\hline Gype & $222 \pm 22$ & 3 & 1 \\
Powerline/dirt road & $205 \pm 77$ & 5 & 2 \\
Shrubby/grapevine impeded clearing & $264 \pm 139$ & 4 & 1 \\
Food plot & $114 \pm 32$ & 26 & 6 \\
Diameter-limit Cut & $0 \pm 0$ & 1 & 1 \\
\hline
\end{tabular}




\section{Chapter 3}

Time Activity Budgets of Cerulean Warblers

(Formatted in the style of the Auk) 


\begin{abstract}
Time-activity budgets of male Cerulean Warblers (Dendroica cerulea) were examined on two sites in Wetzel Co., WV that differed in canopy structure. Singing and foraging were the most frequently observed of 11 documented behaviors. Cerulean Warbler territories were mapped and territory boundaries and core areas were delineated using 95\% and 50\% respective kernel home range estimates. Canopy gaps within territories were also mapped. Pearson chi-square analysis was used to test if activity differed among vegetative strata or tree species. Activity was also tested for differences between core areas and non-core areas and between locations near and outside of canopy gaps. Cerulean Warbler males sang in the upper-canopy and foraged in the lower and mid-canopy more frequently than expected. On one site, singing occurred more frequently than expected within core areas while foraging occurred more frequently than expected in non-core areas. Foraging heights within core areas were higher than those in non-core areas. The allocation of singing and foraging behavior among canopy strata may provide an explanation for the affinity that this species exhibits for a vertically stratified forest canopy.
\end{abstract}

\title{
INTRODUCTION
}

Activity budgets are a means of quantifying the amount of time an individual animal or a particular species may devote to certain behaviors such as foraging, social interactions, vocalizing, and resting (Altmann 1974). Time-activity budgets have been used in wildlife research to gain a better understanding of species habitat relations and energy expenditure, and to compare differences in time allocation of behaviors between sexes, between habitat types, during different stages of molt and different times of the year (Adams et al. 2000, Nocera and Taylor 2000, Graham 2001, Fleischer et al. 2003, and Aborn and Moore 2004). Time-activity budgets have been commonly used for waterfowl and other species that are easily observed for long periods of time, although some studies have been successful at assessing time-behavior allocations in passerines via radio-telemetry (Aborn and Moore 2004).

There has been little research on this topic for Cerulean Warblers. Barg (2002) studied allocations of singing and foraging behavior in male Cerulean Warblers among 
tree species, by nesting stage, and by height at a study site in Ontario. She found 10 of 18 males used tree species in different proportions for singing and foraging, 4 of 10 males increased foraging during the nestling period, and when observations were pooled across individuals, singing occurred higher above ground than foraging. She also examined behavior in core areas and non-cores areas using kernel methods of home range estimation. She found core areas of territories had higher densities of song posts than non-core areas, and that core areas did not appear to be foraging "hotspots" (Barg 2002).

Canopy gaps are thought to be an important resource to Ceruleans. Gaps provide rich foraging opportunities for passerines (Noss 1991, Rotenberry et al. 1995, Smith and Dallman 1996). Higher abundances of some insects are found in gaps as a result of increased foliage amounts due to the increased light available to tree crowns surrounding canopy gaps (Smith and Dallman 1996). The premise that Cerulean Warblers may spend more time near gaps to exploit prey species is hereafter referred to as the "foraging hypothesis". Cerulean Warblers placed nest sites within 30m of a canopy gap in Ontario (Olinaryk 1996) and may select core areas of territories within areas of high gap density (Chapter 2). They may also use song posts near gaps for greater song projection due to lessened attenuation and reverberations off foliage (Barg 2002). This is hereafter referred to as the "song propagation hypothesis".

My study examined the time-activity budgets of Cerulean Warblers on two ridges on the Lewis Wetzel Wildlife Management Area in Wetzel Co., West Virginia. The objectives were to 1) identify the behaviors and allocated time during the breeding season (approximately the end of April to the end of June on this study site), 2) determine if activity varied by tree species or canopy height on either ridge, and 3) determine if certain activities, especially singing and foraging, occurred more frequently than expected near gaps or within core areas of the territory on our study site in West Virginia.

\section{STUDY AREA}

The study area, Lewis Wetzel Wildlife Management Area (LW), located in Wetzel County near Jacksonburg, WV, consists of 5,418 ha ranging in elevation from $224-476 \mathrm{~m}$. The site was predominantly mature second-growth forest with three relatively small clearcuts less than 15ha in size harvested in 1996 and 1997. The site may be 
classified as mixed mesophytic or Appalachian oak forest according to its location in West Virginia (Martin et al. 1993). Two ridges, Hart Ridge and Snake Ridge, on LW were surveyed for Cerulean Warblers during the 2005 breeding season. The two ridges were different in structure and species composition which may be the result of a past history of agriculture on Hart Ridge. Hart Ridge, a mostly mesic site, had a trail that followed the ridgeline and three maintained wildlife openings that were between 0.17 and 0.32 ha in area, located on the broadest sections of the ridge. Abundant tree species on this site were sugar maple (Acer saccarum), red oak (Quercus rubra), yellow-poplar (Liriodendron tulipifera), white ash (Fraxinus americana), hickory (Carya spp.), black cherry (Prunus serotina), black walnut (Juglans nigra) and black locust (Robinia pseudoacacia). Snake Ridge, a taller steeper ridge, had a dry ridge-top with rocky soil, and dry or mesic side-slopes. Codominant species on the ridge-top were chestnut oak $(Q$. prinus) and scarlet oak (Q. coccinea). Other common species on this site were several

hickory species, northern red oak, black oak (Q. velutina), white oak (Q.alba), white ash, basswood (Tilia Americana), tulip-poplar, sugar maple, and cucumber magnolia (Magnolia acuminata). Red maple (A. rubrum) was present on both sites but was not generally a canopy tree. Snake Ridge had no recent anthropogenic disturbances at the time of the study.

\section{METHODS}

\section{Field Methods}

Methods of territory delineation followed Barg et al. (2005). Observed Cerulean locations were collected in sampling bursts rather than by sequential sampling to maximize the number of points taken over a short period of time. Each male Cerulean was followed for 30 minutes every three to five days and a location was flagged every minute. A time delay of two minutes preceded recording locations in order to reduce bias towards conspicuous sites. If a bird was lost during the 30 minute sampling period, each minute it was unaccounted for was recorded as a lost data point. At least eight flags or fifteen minutes observing the bird within a 30 minute period was used as the minimum locations required for a survey. Sampling was conducted in May through June of 2005 during morning hours (0600-1130). 
Bird activity (Table 1) was recorded only for each minute that the observer actually had the bird in view. Observers recorded the activity of the birds at the first second of every new minute. One observer with a stop watch would count down the seconds until the minute turned while another observer would watch the bird through binoculars and identify the activity during the first second of the new minute. The tree species and vegetative strata of the bird were also recorded for each activity (Table 1). Vegetative strata were recorded according to class (understory, midstory, lower-canopy, mid-canopy, and upper-canopy) where each stratum represented a $20 \%$ increment measured starting with the forest floor through the upper canopy layer. In forestry terms, the three canopy classes (mid, lower, and upper canopy) would be in the overstory. Dominant and codominant trees would have crowns in the mid and upper canopy levels, intermediates would be split into the mid and lower canopy, and overtopped trees would be in the midstory and below.

Additional observations of the tree species and vegetative strata were recorded when the location of the bird was known at the sampling time, but the activity could not be witnessed because the bird was obscured by vegetation. No activity was recorded if the observer did not have the bird in view when the minute turned, even if the bird was still heard singing during the sampling time because male Ceruleans sometimes sang while engaged in another activity and this would bias estimates towards singing. Singing was observed in conjunction with another activity in $4 \%$ of the total observations. When this occurred both observations were recorded but for analysis purposes only what was considered the dominant activity was included.

Foraging included all food related activities such as gleaning insects but also hopping along a branch actively searching for prey, and one observation of a Cerulean Warbler beating a caterpillar against a twig. Perching was recorded for birds that were observed sitting still and not singing. When a bird was perched singing this was recorded as singing. Hopping was recorded separately from foraging when the bird had its head up while moving along the branch and appeared to be using this behavior as a means of locomotion instead of actively searching for prey. "Dancing" (termed by M. Lutmerding) was a unique behavior where the male Cerulean elevated his wings slightly without opening them and moved them back and forth in a wiggling motion that was thought to 
be a courtship display (R. Dettmers pers. comm.). Other behaviors that were witnessed less than three times each were fanning tail feathers, fluffing out feathers, and fluttering wings while perched. These behaviors did not fit a category and were reported as singing if observed while the bird was singing and were otherwise reported as perching for analysis purposes.

\section{GIS Methods}

In late June and in July, flagged bird locations were revisited and GPS coordinates were taken with GeoExplorer CE series Trimble units. Coordinates were corrected using GPS Pathfinder software and were accurate from 0.5 to $4.5 \mathrm{~m}$. I used the animal movement extension in ArcView 3.2 with the least squares cross validation method of selecting a smoothing parameter to create $95 \%$ kernel home range estimates for seven birds on Snake Ridge and 14 birds on Hart Ridge. Core area estimates were also obtained for these territories using the 50\% kernel density isopleth. Canopy gaps were digitized using field sketches and GPS points. I overlaid canopy gap and kernel territory shapefiles on 2003 DOQQs in UTM NAD83 State Plane West Virginia north using ArcGIS 9.0 software. See chapter 2 for a more detailed description of creating shapefiles of canopy gaps and kernel territory estimates.

I created a separate point shapefile including the bird locations that had at least one activity observation. To determine whether a bird activity observation was located in or out of a core area for each territory, I clipped the new point shapefile by the $50 \%$ kernel estimate and exported the table into Microsoft Excel for analysis purposes. To determine whether a bird activity observation was located next to or in a canopy gap, I first created a merged shapefile of all gaps for each territory. I repeated the clipping procedure with the activity points layer and the merged gap layer using a cluster tolerance of one meter. This produced a point layer of all activity locations for each territory that were found within one meter of a canopy gap. The cluster tolerance of one meter was used to mediate some of the GPS error that likely resulted in some bird activity locations that were actually located on the edge of a canopy gap not being included in the new point shapefile when it was clipped. 


\section{Statistical Analyses}

I used Pearson chi-square tests of independence in SAS V8 to first determine if activity, tree species, or height class differed between the two study areas. Because all three variables differed between the two ridges (Table 2), data were tested separately for the two sites.

I used Pearson chi-square tests of independence to determine if activity varied by vegetative strata or by tree species. On Snake Ridge, only singing and foraging were tested among vegetative strata because there were a limited number of other activities observed. Activity was not tested by tree species on this site because the number of tree species combined with the low number of activity observations other than singing made the individual cell counts within the chi-square too low for a valid test. On Hart Ridge, singing, perching, foraging, and preening were tested among vegetative strata while only singing and foraging were tested among tree species.

Chi-square analysis was used to determine if activity differed between observations within and outside of core areas and canopy gaps. I also used this test to determine whether singing or foraging height differed between observations located within or outside of core areas.

Standardized residuals were calculated for all cells in chi-square tests with significant outcomes by the equation [(observed-expected)/ Vexpected] (Reynolds 1977, Newman and Waters 1984, Smith and Iverson 2004). The farther the value of the standardized residual was from zero, the more important the difference between the observed and expected cell value was to the outcome of the test. Values greater than \pm 1 , especially those approaching \pm 2 , are considered important while values near zero indicate little difference between observed and expected values (Acastat Handbook 2004, Smith and Iverson 2004).

\section{RESULTS}

Observations of activities, tree species, and vegetative strata were obtained for 20 Cerulean Warbler males on Hart Ridge and for nine on Snake Ridge. Of these individuals, territories were delineated for 14 males on Hart Ridge and 7 males on Snake Ridge. 
Of the 11 behaviors recorded (Table 1), singing was by far the most common followed by foraging (Fig. 1). Other behaviors that were witnessed less often were preening, bathing, perching, flying, dancing, interaction with a female Cerulean Warbler, aggressive intraspecific interaction, and one instance of an interspecific interaction when a Cerulean Warbler male was chased by a male Scarlet Tanager (Piranga olivacea).

Activities (Fig. 1), use of tree species (Fig. 2), and vegetative strata (Fig. 3) differed between Hart Ridge and Snake Ridge (Table 2). Therefore, remaining results are reported separately for each site. There were few observations of Cerulean Warblers in the $0-20 \%$ (understory) stratum (Fig. 3) so this class was omitted from all analyses.

Activity did not differ between tree species on Hart Ridge (Table 2). There were not enough observations of activities other than singing to test this on Snake Ridge. Activity differed among vegetative strata on Hart Ridge (Table 2) with singing occurring in the upper-canopy more frequently than expected and foraging occurring in the midcanopy and lower-canopy more frequently than expected (Table 3). Activity also differed between core areas and non-core areas on Hart Ridge (Table 2) and approached significance on Snake Ridge $(P=0.09)$. On Hart Ridge foraging had the strongest difference between observed and expected cell values as indicated by the standardized residual values greater than \pm 2 (Table 4). Foraging occurred more often than expected in non-core areas while singing was observed more frequently than expected within core areas (Table 4). On Snake Ridge, there was little difference between singing in core areas and non-core areas, while foraging and preening both occurred less often than expected within core areas (Table 4).

Singing heights differed between core areas and non-core areas on both Hart Ridge and Snake Ridge (Table 2). On Hart Ridge singing locations were observed more often than expected in the upper-canopy and less than expected in the mid-canopy (Table 5). On Snake Ridge singing locations were observed relatively equal to expected in the upper-canopy and the greatest difference was found among the mid-story where singing observations occurred in core areas less often than expected.

Foraging height also differed between core areas and non-core areas on Hart Ridge (Table 2). The greatest difference between observed and expected values was in mid-canopy vegetative strata where observations in core areas occurred in this stratum 
more frequently than expected (Table 5). There were not enough foraging observations to test this on Snake Ridge.

Thirty-four percent ( $n=234$ of 685) of bird observations on Hart Ridge were located in or on the edge of a canopy gap while $19 \%(n=54$ of 278$)$ of bird observations were located in or on the edge of a canopy gap on Snake Ridge. Activity did not differ between locations in or on the edge of gaps from those located outside of gaps on either site (Table 2).

\section{DISCUSSION}

The Cerulean Warbler is a canopy associated species. They forage by gleaning insects off leaves and twigs in the forest canopy, nest in the forest canopy at heights exceeding 30m, and sing in the canopy (Hamel 2000a, Hamel 2000b). However, information regarding what canopy levels are exploited for activities such as singing and foraging is limited. Barg (2002) reported mean singing heights of $15 \mathrm{~m}$ which was higher than foraging heights of $12.8 \mathrm{~m}$ in Ontario. Cerulean Warblers were also found to sing higher than they foraged on Hart Ridge on our study site. These differences were not detected on Snake Ridge however, probably because of the low sample size of foraging observations $(n=15)$ compared to singing observations $(n=167)$. This allocation of activity by vegetative strata may be an important reason why Cerulean Warblers prefer a vertically stratified canopy. It is also important to note that although use of the uppercanopy $(81-100 \%)$ vegetative strata for singing $(n=73)$ was greater than expected on Hart Ridge, singing was also frequently observed in the lower-canopy (41-60\%) $(n=116)$ and mid-canopy $(61-80 \%)(\mathrm{n}=128)$ categories.

It is somewhat surprising that time allotted to certain activities varied between two ridges located $\sim 0.5 \mathrm{~km}$ apart on the same wildlife management area, although this may be due in part to the difference in canopy structure on the two ridgetops. Hart Ridge had a more broken, lower canopy with heights ranging from around 18-24 m while canopy trees on Snake Ridge were often 25-30 m tall. The difference in canopy structure may have made foraging observations easier to obtain on Hart Ridge than on Snake Ridge although if this were the sole reason then preening and perching observations should have been higher as well on Hart Ridge which was not the case (Fig. 1). It is also 
possible that insect abundances may have been higher on Hart Ridge and so birds were observed foraging or in foraging bouts more frequently than on Snake Ridge.

Observations in the lower-canopy made up a higher percentage of the overall bird observations on Snake Ridge than on Hart Ridge (Fig. 3) which is most likely accounted for by the difficulty of observing birds at the higher canopy heights on Snake Ridge. Tree species use also differed between the sites which is likely a result of differences in availability and species composition of the stands between the two sites (Table 2, Fig. 2).

The findings of this study that singing occurred more frequently than expected within core areas on Hart Ridge is not surprising considering that core areas are defined as the region of the territory comprised of $50 \%$ of the bird locations. These were likely areas in the field where males were singing and moving from tree to nearby tree permitting observers to collect many bird locations all at once. However, the findings that foraging occurred more frequently than expected outside of core areas on both sites is surprising. If core areas were used as foraging hotspots in conjunction with good locations to sing, foraging would have been observed at least as often as expected within core areas as in non-core areas. Potentially, Cerulean Warbler males are using core areas primarily as singing locations and are foraging within them only opportunistically. A study in Ontario also found that song-post densities were higher within core areas and that core areas did not serve as foraging "hotspots" (Barg 2002). Barg (2002) hypothesized that core areas may be selected primarily for song projection. Collections of song-posts were hypothesized to be located near canopy gaps or trees with less dense foliage where song attenuation and reverberations off foliage reduced. My study found no significant differences between observed and expected values of activities that occurred within or adjacent to gaps although gap densities were found to be highest within core areas (Chapter 2). Core areas are probably selected for a combination of complex reasons which may include good singing locations where gaps are abundant but also could potentially serve as strategic locations in territorial defense especially where Cerulean densities are high.

Cerulean Warblers are often found in semi-clusters of territories (Hamel 2000a) and most territories mapped on both ridges on Lewis Wetzel had multiple neighbors. Cerulean Warbler males would frequently move to a new singing location to counter-sing 
in proximity to another male that approached a common territory boundary (pers. obs.). This would, in some instances, allow a third neighbor to move in closer to an opposite boundary while the other two males were busy counter-singing. This behavior was so pronounced among individuals in some locations that edges of territory boundaries overlapped. Locations of core areas may serve as strategic locations for territorial defense among multiple neighbors in addition to selection for desirable perches. More research is needed to determine the purpose and selective characteristics of core areas.

Singing and foraging heights were also found to differ between locations within core areas and locations outside of core areas (Table 2). This last finding may be, in part, due to the lower sample sizes of bird observations at these heights on Snake Ridge but may also be due to the differences in canopy height and structure between the two ridges. Perhaps most importantly, singing observations occurred more frequently in higher vegetative strata than expected in core areas versus non-core areas on both sites. This supports both the song propagation hypothesis for core areas and the territorial defense hypothesis because higher perch locations within core areas may enhance song broadcast to neighbors. Foraging height was also found to differ among locations inside and out of core areas on Hart Ridge (Table 2). The lower sample of foraging observations on Snake Ridge did not permit analysis for this site. These findings differ from the analysis of activity by canopy height that found Cerulean Warblers on Hart Ridge foraged more often than expected in the lower-canopy strata. Male Cerulean Warblers may be foraging slightly higher in core areas compared with non-core areas due to differences in prey abundance. However, it seems more likely that they may opportunistically forage higher in core areas in conjunction with singing since singing occurred at higher canopy levels and the foremost purpose of core areas appears to be for singing. Further research is needed to determine the characteristics of certain resources Ceruleans may be exploiting in core areas such as song-posts or foraging opportunities to a gain a better understanding of Cerulean habitat requirements. 


\section{LITERATURE CITED}

AcaStat Software. 2004. Research Methods Handbook. http://acastat.com.

Altmann, J. 1974. Observational study of behavior: sampling methods. Behaviour 49:227-267.

Aborn, D. A. and F. R. Moore. 2004. Activity budgets of Summer Tanagers during spring migratory stopover. Wilson Bulletin 116:64-68.

Adams, P. A., G. J. Robertson, and I. L. Jones. 2000. Time-activity budgets of Harlequin Ducks molting in the Gannet Islands, Labrador. Condor 102:703 -708 .

Barg, J. J. 2002. Small-scale biological phenomena in a male Neotropical migrant songbird. M.S. Thesis, Queen's University Kingston, Ontario, CA.

Barg, J. J., J. Jones, and R. J. Robertson. 2005. Describing breeding territories of migratory passerines: suggestions for sampling, choice of estimator, and delineation of core areas. Journal of Animal Ecology 74:139-149.

Fleischer Jr., A. L., R. Bowman, and G. E. Woolfenden. 2003. Variation in foraging behavior, diet, and time of breeding of Florida Scrub-Jays in suburban and wildland habitats. Condor 105:515-527.

Graham, C. 2001. Habitat selection and activity budgets of Keel-billed Toucans at the landscape level. Condor 103:776-784.

Hamel, P. B. 2000a. Cerulean Warbler (Dendroica cerulea). The Birds of North America, No. 511 (A. Poole and F. Gill, Eds.). The Birds of North America, Inc., Philadelphia, PA.

Hamel, P. B. 2000b. Cerulean Warbler status assessment. United States Fish and Wildlife Service, Fort Snelling, MN.

Martin, W. H., S. G. Boyce, A. C. Echternacht. 1993. Appalachian oak forests. Pages 255-303 in Biodiversity of the Southeastern United States Upland Terrestrial Communities. John Wiley \& Sons, Inc. New York.

Newman, R. M. and T. F. Waters. 1984. Size-selective predation on Gammarus pseudolimnaeus by trout and sculpins. Ecology 65:1535-1545.

Nocera, J. J., and P. D. Taylor. 2000. Behavior of post-nest failure and non-breeding Common Loons during the breeding season. Wilson Bulletin 112:532-534. 
Noss, R. F. 1991. Effects of edge and internal patchiness on avian habitat use in an old growth Florida hammock. Natural Areas Journal 11:34-47.

Oliarnyk, C. J. and R. J. Robertson. 1996. Breeding behavior and reproductive success of Cerulean Warblers in southeastern Ontario. Wilson Bulletin 108:673-684.

Reynolds, H.T. 1977. The analysis of cross-classifications. Free Press, New York, New York, USA.

Rotenberry, J. T., R. J. Cooper, J. M. Wunderle, and K. G. Smith. 1995. When and how are populations limited? The roles of insect outbreaks, fire, and other natural perturbations. Pages 55-84 in T. E. Martin and D. M. Finch, Eds. Ecology and Management of Migratory Birds: A Synthesis and Review of Critical Issues. Oxford University Press, Oxford, England.

Smith, R., and M. Dallman. 1996. Forest gap use by breeding Black-throated Green Warblers. Wilson Bulletin 108:588-591.

Smith, G. R. and J. B. Iverson. 2004. Diel activity patterns of the turtle assemblage of a northern Indiana lake. American Midland Naturalist 152:156-164. 
TABLE 1. Observations of Cerulean Warbler males by activity, vegetative strata, and tree species in Wetzel County, WV collected during morning hours (0600-1130) in May through June 2005.

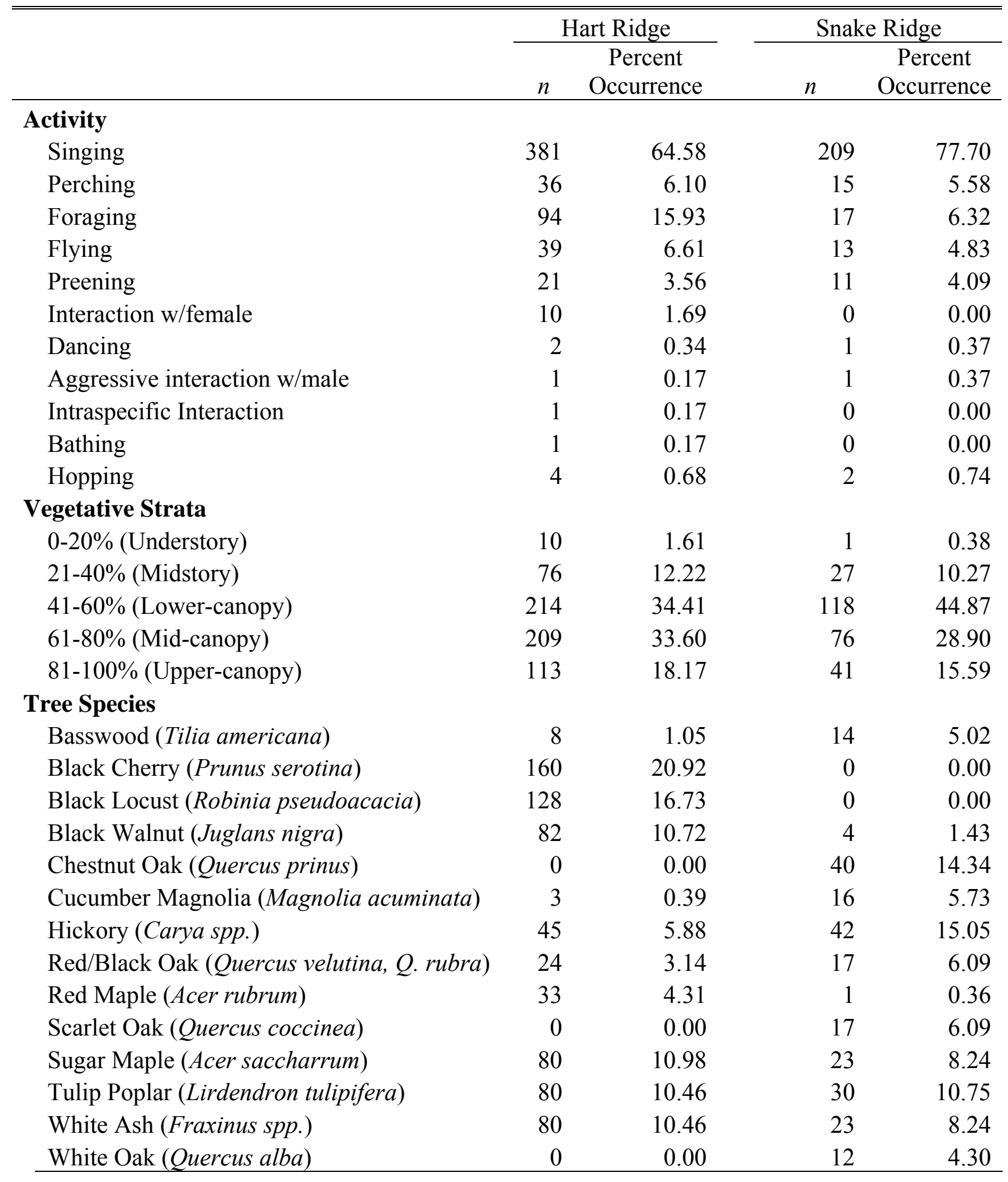


TABLE 2. Results of chi-square analysis of Cerulean Warbler observations on the Lewis Wetzel Wildlife Management Area in Wetzel County, WV (May-June 2005).

\begin{tabular}{|c|c|c|c|c|c|c|c|c|c|}
\hline \multirow[b]{2}{*}{ Variable 1} & \multirow[b]{2}{*}{ Variable 2} & \multirow[b]{2}{*}{ Site } & \multicolumn{3}{|c|}{ Chi-square } & \multicolumn{4}{|c|}{ Fisher's exact } \\
\hline & & & $\chi^{2}$ & $\mathrm{df}$ & $P$ & Table & $P$ & $\%$ cells $<5$ & $n$ \\
\hline Site & Activity & - & 23.59 & 5 & 0.0003 & - & - & - & 846 \\
\hline Site & Tree Species & - & 523.80 & 10 & $<0.0001$ & - & - & - & 1134 \\
\hline Site & Vegetative Strata & - & 10.22 & 4 & 0.0370 & - & - & - & 885 \\
\hline Activity $^{\mathrm{a}}$ & Vegetative Strata & SR & 1.50 & 3 & 0.6814 & 0.0152 & 0.7810 & 38 & 184 \\
\hline Activity & Vegetative Strata & $\mathrm{HR}$ & 19.56 & 9 & 0.0209 & - & - & - & 498 \\
\hline Activity $^{a}$ & Tree Species & $\mathrm{HR}$ & 10.86 & 8 & 0.2095 & - & - & - & 436 \\
\hline Activity & In Core Area & SR & 6.52 & 3 & 0.0887 & - & - & - & 214 \\
\hline Activity & In Core Area & $\mathrm{HR}$ & 18.31 & 3 & 0.0004 & - & - & - & 440 \\
\hline Activity & In a Gap & $\mathrm{SR}$ & 5.86 & 3 & 0.1188 & 0.0037 & 0.1707 & 38 & 214 \\
\hline Activity & In a Gap & HR & 3.84 & 3 & 0.2789 & - & - & - & 440 \\
\hline In Core Area & Singing Height & $\mathrm{SR}$ & 8.85 & 3 & 0.0310 & - & - & - & 139 \\
\hline In Core Area & Singing Height & HR & 10.41 & 3 & 0.0150 & - & - & - & 297 \\
\hline In Core Area & Foraging Height & $\mathrm{HR}$ & 9.18 & 3 & 0.0270 & 0.0003 & 0.0320 & 25 & 75 \\
\hline
\end{tabular}

\footnotetext{
${ }^{\mathrm{a}}$ Indicates a test using only foraging and singing as activities.
} 
TABLE 3. Observed and expected values from chi-square analysis display differences in frequency of observed activities among vegetative strata for Cerulean Warblers on Hart Ridge, located on the Lewis Wetzel Wildlife Management Area in Wetzel County, WV (May-June 2005). The standardized residual values farthest from zero indicate the greatest differences between observed and expected values of individual cells.

\begin{tabular}{lcccc}
\hline \hline & \multicolumn{4}{c}{ Vegetative Strata } \\
\cline { 2 - 5 } Activity & Midstory & $\begin{array}{c}\text { Lower- } \\
\text { canopy }\end{array}$ & $\begin{array}{c}\text { Mid- } \\
\text { canopy }\end{array}$ & $\begin{array}{c}\text { Upper- } \\
\text { canopy }\end{array}$ \\
\hline Singing & & & 128 & 73 \\
Observed & 36 & 116 & 128.30 & 60.25 \\
Expected & 40.40 & 124.05 & -0.03 & 1.64 \\
Std. Resid. & -0.69 & -0.72 & & \\
Perching & & & 11 & 1 \\
Observed & 6 & 14 & 11.63 & 5.46 \\
Expected & 3.66 & 11.25 & -0.18 & -1.91 \\
Std. Resid. & 1.22 & 0.82 & & \\
Foraging & & & 30 & 9 \\
Observed & 14 & 39 & 33.44 & 15.70 \\
Expected & 10.53 & 32.33 & -0.59 & -1.69 \\
Std. Resid. & 1.07 & 1.17 & & \\
Preening & & & 12 & 2 \\
Observed & 1 & 6 & 7.63 & 3.58 \\
Expected & 2.40 & 7.38 & 1.58 & -0.84 \\
Std. Resid. & -0.90 & -0.51 & & \\
\hline
\end{tabular}


TABLE 4. Observed and expected values from chi-square analysis indicate that frequency of Cerulean Warbler activities differ from locations within and outside of core areas on two sites in Wetzel County, WV (May-June 2005). The standardized residual values farthest from zero indicate the greatest differences between observed and expected values of individual cells.

\begin{tabular}{cccccc}
\hline \hline & \multicolumn{2}{c}{ Hart Ridge } & & \multicolumn{2}{c}{ Snake Ridge } \\
\cline { 2 - 3 } \cline { 5 - 6 } Activity & Core & Non-core & & Core & Non-core \\
Area & Area & & Area & Area \\
\hline Singing & & & & & \\
Observed & 185 & 131 & & 97 & 81 \\
Expected & 168.05 & 147.95 & & 93.16 & 84.84 \\
Std. Resid. & 1.31 & -1.39 & & 0.40 & -0.42 \\
Perching & & & & & \\
Observed & 12 & 18 & & 7 & 3 \\
Expected & 15.96 & 14.05 & & 5.23 & 4.77 \\
Std. Resid. & -0.99 & 1.05 & & 0.77 & -0.81 \\
Foraging & & & & & \\
Observed & 26 & 51 & & 5 & 10 \\
Expected & 40.95 & 36.05 & & 7.85 & 7.15 \\
Std. Resid. & -2.34 & 2.49 & & -1.02 & 1.07 \\
Preening & & & & & \\
Observed & 11 & 6 & & 3 & 8 \\
Expected & 9.04 & 7.96 & & 5.76 & 5.24 \\
Std. Resid. & 0.65 & -0.69 & & -1.15 & 1.21 \\
\hline
\end{tabular}


TABLE 5. Observed and expected values of chi-square analysis display differences in frequency of observed activities among vegetative strata for Cerulean Warblers on Hart Ridge (HR) and Snake Ridge (SR), located on Lewis Wetzel Wildlife Management Area in Wetzel County, WV (May-June 2005). The standardized residual values farthest from zero indicate the greatest differences between observed and expected values of individual cells.

\begin{tabular}{|c|c|c|c|c|c|c|}
\hline \multirow[b]{2}{*}{$\begin{array}{l}\text { Vegetative } \\
\text { Strata }\end{array}$} & \multicolumn{2}{|c|}{ Singing (HR) } & \multicolumn{2}{|c|}{ Singing (SR) } & \multicolumn{2}{|c|}{ Foraging (HR) } \\
\hline & $\begin{array}{l}\text { Core } \\
\text { Area } \\
\end{array}$ & $\begin{array}{c}\text { Non-core } \\
\text { Area } \\
\end{array}$ & $\begin{array}{l}\text { Core } \\
\text { Area } \\
\end{array}$ & $\begin{array}{c}\text { Non-core } \\
\text { Area }\end{array}$ & $\begin{array}{l}\text { Core } \\
\text { Area } \\
\end{array}$ & $\begin{array}{c}\text { Non-core } \\
\text { Area }\end{array}$ \\
\hline \multicolumn{7}{|l|}{ Midstory } \\
\hline Observed & 18 & 14 & 6 & 17 & 1 & 8 \\
\hline Expected & 18.75 & 13.25 & 10.92 & 12.08 & 3 & 6 \\
\hline Std. Resid. & -0.17 & 0.21 & -1.49 & 1.42 & -1.15 & 0.82 \\
\hline \multicolumn{7}{|l|}{ Lower-canopy } \\
\hline Observed & 45 & 49 & 38 & 29 & 9 & 22 \\
\hline Expected & 55.07 & 38.93 & 31.81 & 35.19 & 10.33 & 20.67 \\
\hline Std. Resid. & -1.36 & 1.61 & 1.10 & -1.04 & -0.41 & 0.29 \\
\hline \multicolumn{7}{|l|}{ Mid-canopy } \\
\hline Observed & 62 & 42 & 10 & 18 & 14 & 12 \\
\hline Expected & 60.93 & 43.07 & 13.3 & 14.71 & 8.67 & 17.33 \\
\hline Std. Resid. & 0.14 & -0.16 & -0.90 & 0.86 & 1.81 & -1.28 \\
\hline \multicolumn{7}{|l|}{ Upper-canopy } \\
\hline Observed & 49 & 18 & 12 & 9 & 1 & 8 \\
\hline Expected & 39.25 & 27.75 & 9.97 & 11.03 & 3 & 6 \\
\hline Std. Resid. & 1.56 & -1.85 & 0.64 & -0.61 & -1.15 & 0.82 \\
\hline
\end{tabular}




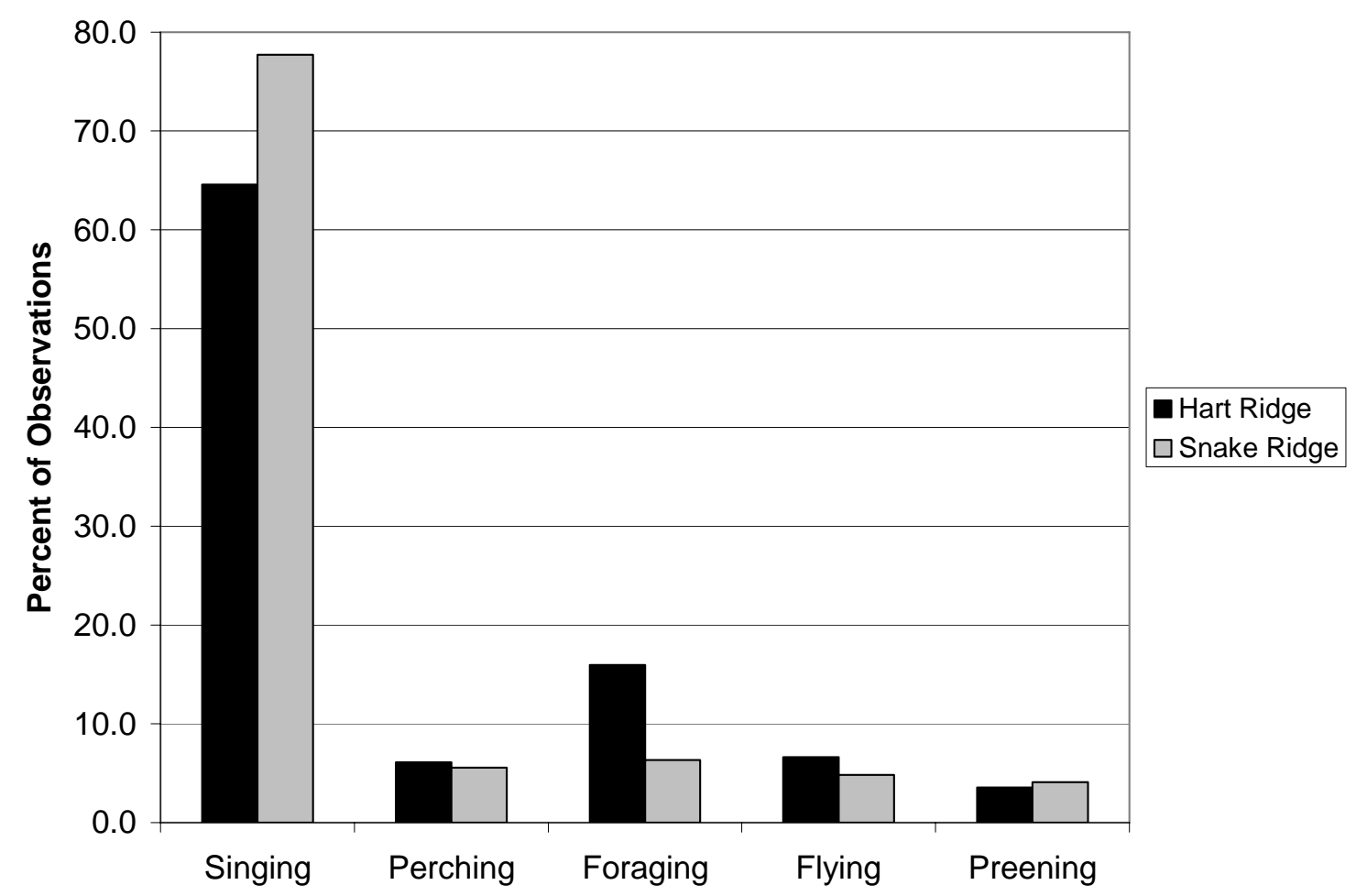

FIG. 1. Percent of observations of Cerulean Warbler activities by site in Wetzel County, WV, collected May through June 2005. 


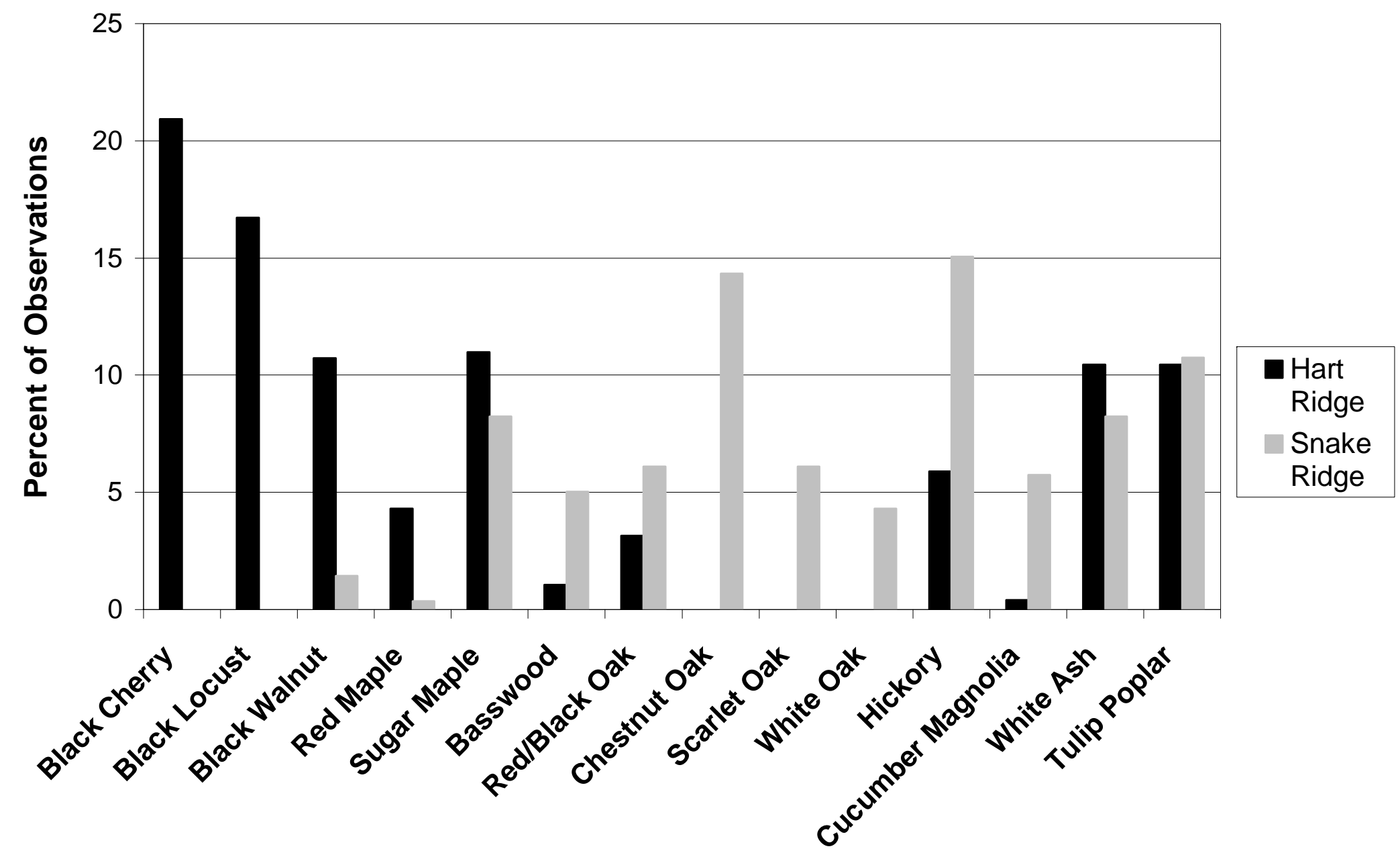

FIG. 2. Percent occurrence of Cerulean Warbler observations among tree species on two sites in Wetzel County, WV, collected May through June 2005. 


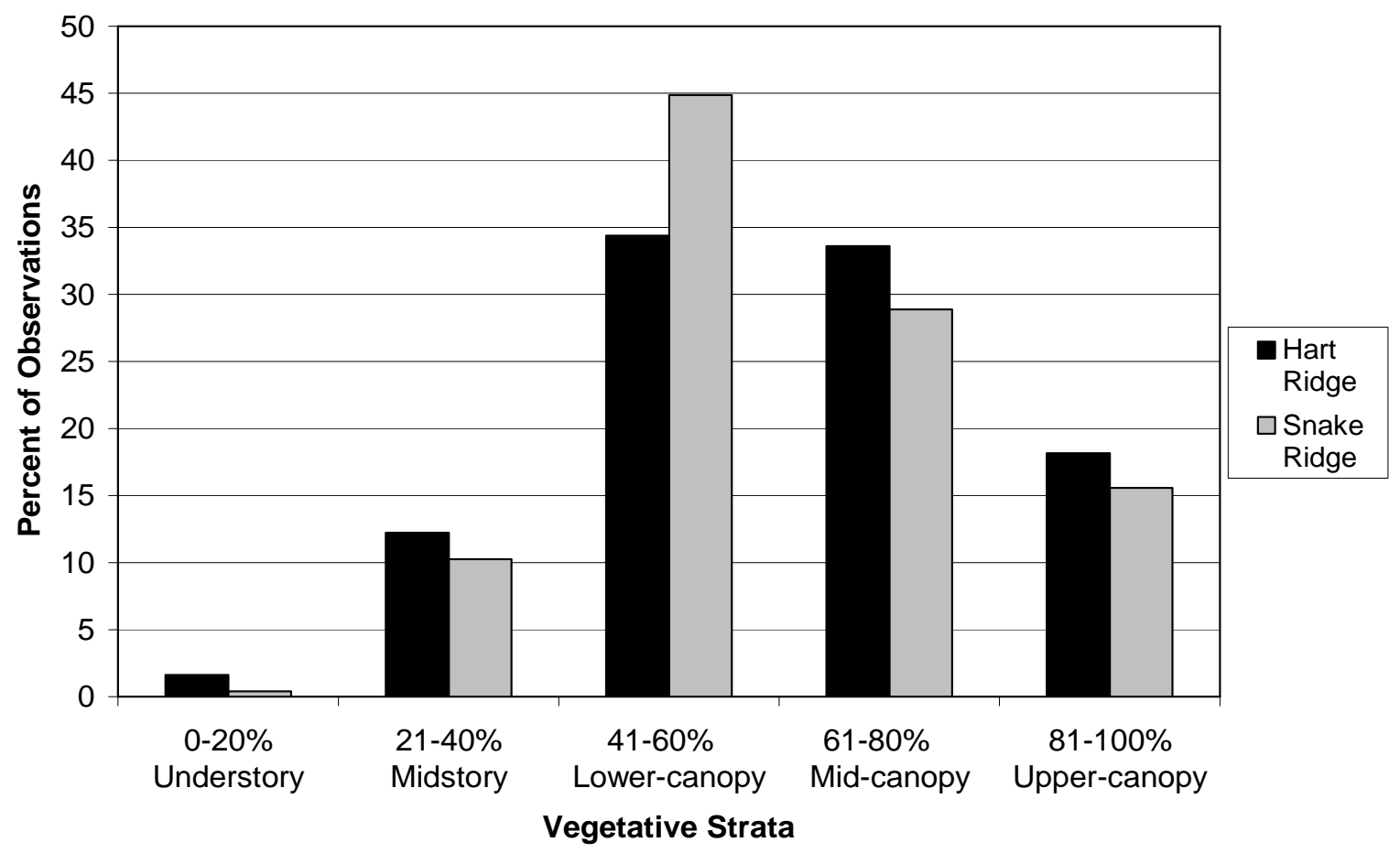

FIG. 3. Percent of observations of Cerulean Warblers by vegetative height class on two sites in Wetzel County, WV collected May through June 2005. 